\title{
MONTHLY REPORT
}

MAY 1961

HANFORD ATOMIC PRODUCTS OPERATION

\section{GENERAL GLCTRIC}

RICHLAND, WASHINGTON

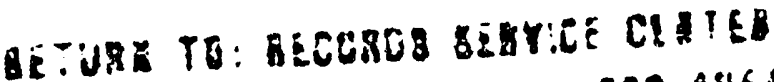

DULDINC 712

360 A8EA

SaX LUYBER COZ694 B:D 0173

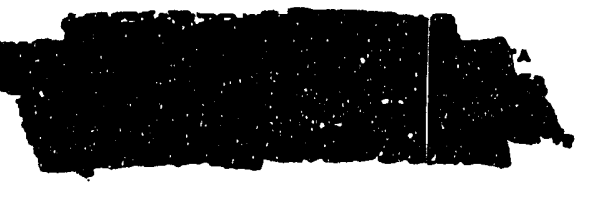

1. DECLASSIFIED 


\section{LEGAL NOTICE}

This report was prepared as an account of Government sponsored work. Neither the United States, nor the Commission, nor any person acting on behalf of the Commission:

A. Makes any warranty or representation, expressed or implied, with respect to the accuracy, completeness, or usefulness of the information contained in this report, or that the use of any information, apparatus, method, or process disclosed in this report may not infringe privately owned rights; or

B. Assumes any liabilities with respect to the use of, or for damages resulting from the use of any information, apparatus, method, or process disclosed in this report.

As used in the above, "person acting on behalf of the Commission" includes any employee or contractor of the Commission, or employee of such contractor, to the extent that such employee or contractor of the Commission, or employee of such contractor prepares, disseminates, or provides access to, any information pursuant to his employment or contract with the Cornmission, or his employment with such contractor. 


\section{HAN-790/?}

HW- 69835

This document consists of

Si pages.

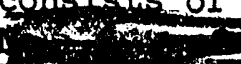

$=$

IRRADIATION PROCESSING DEPARTMENT

MONTHLY REPORT

MAY, 1961

79017

Compiled by

IPD Personnel

June 15, 1961

RICHIAND, WASHINGTON

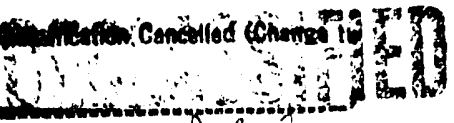

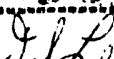

- mothorty oxdedxitust

$z-4-92$ CG.PR 2

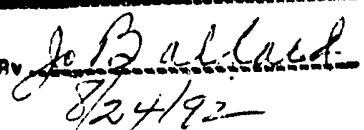

Work performed under Contract No. AT (45-1)-1350 between the Am $\varepsilon_{10 K}>24-9: 2$ Atomic Energy Commission and the General Flectric Company.

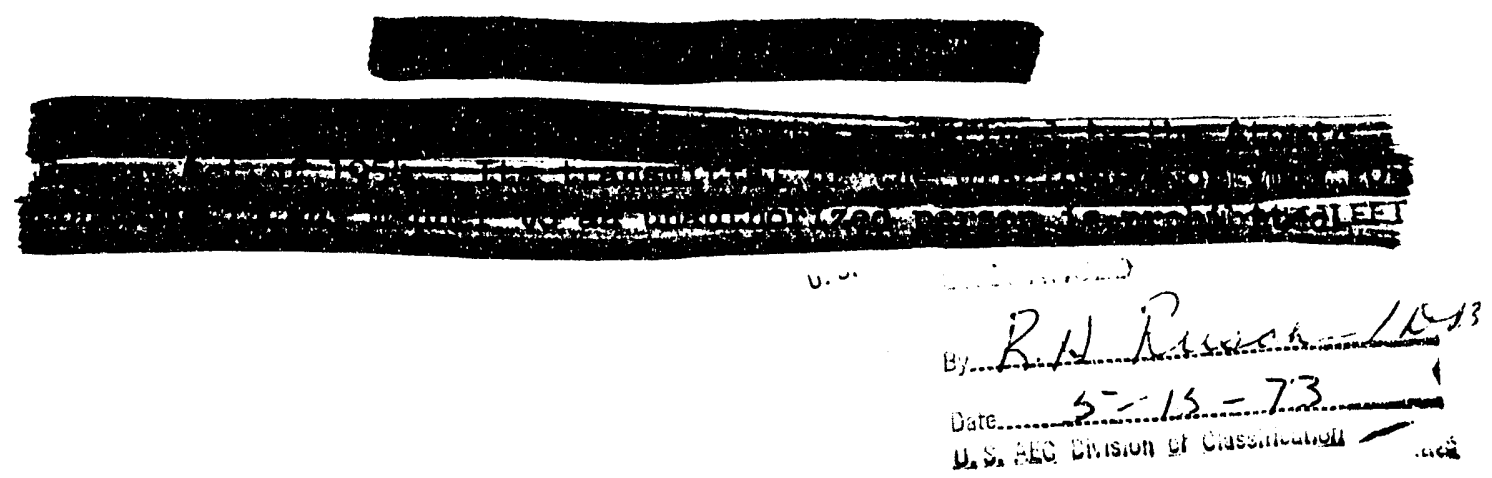

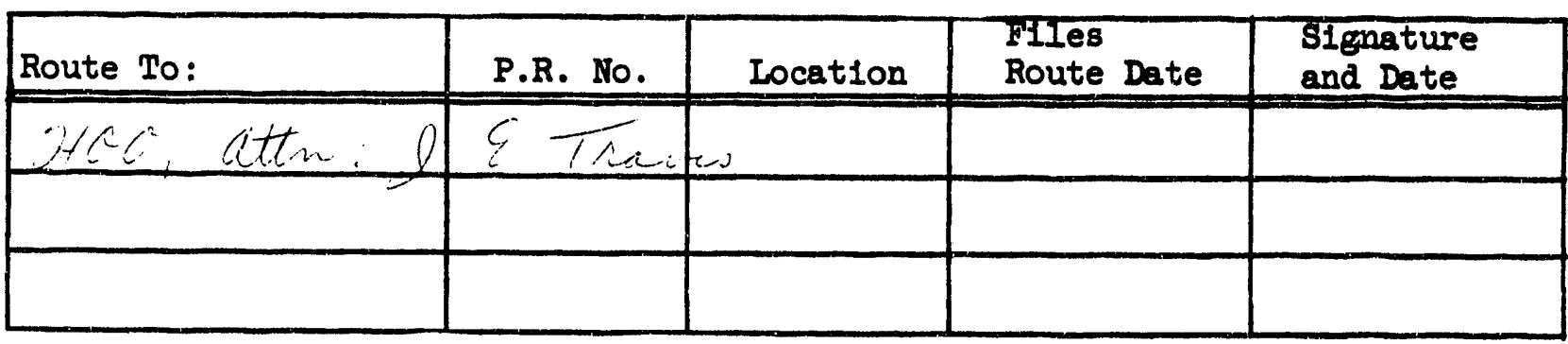
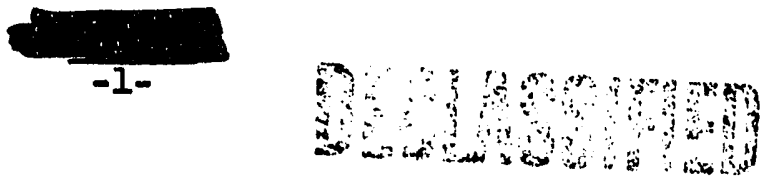

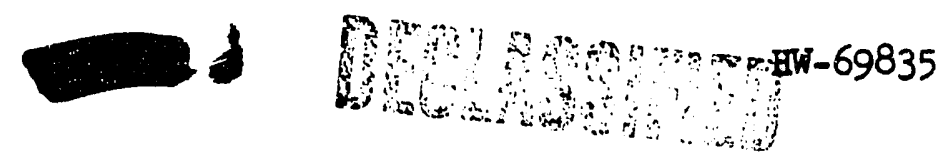

DISTRIBUTION

Copy Number

1

2

3

4

$5-6-7-8$

9-10

11

12

13

14

15

16

17

18

19

20
W. E. Johnson

A. B. Greninger

H. M. Parker

APD, F. E. Crever

AEC-HOO, J. E. Trav1s

AEC Production Division, G. F. Quinn

ABC-SROO, R. C. Blalr

R. I. Dickeman

0. H. Greager

R. T. Jessen

O. C. Schroeder

W. A. Shanks

J. S. Mcliahon

S. H. Small

300 Area F1le

Ilesords Center

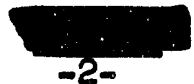


TABIE OF CONTENTS

SUMMARY

A-1

GENERAI

A-4

RESEARCH \& FNGINEHRING

Process and Reactor Development Operation

B-1

Process Technology Operation

B-9

Operational Physics Operation

B-17

Testing Operation

B-22

MANUFACIURING

Production Operation

Reactor Operation Stitistics

$\mathrm{C}-1$

Applied Reactor Bnglneering Operation

C-2

B-C Reactor Operation

C-7

D-DR Reactor Operation

C-8

F Reactor Operation

C-10

I Reactor Operation

C-11

KOH-KW Reactor Operation

C-13

C-15

\section{FACIIIIIES ENGINHWRING}

Reactor Modiflcation Deslgn Operation

D-1

Equipment Development Operation

D-3

Plant Engineering Operation

D-5

Project Engineering Operation

D-7

NPR PROJECI

Process Design

Field and Operat1ons Englneering

Program Evaluation

E-1

E-4

E-8

FINANCIAL

F-I

RETATIONS PRACTICES

G-1

SIGNIFICANT? REPORTS ISSUED

H-1

TRIPS

B- -4

VISITORS

B-7

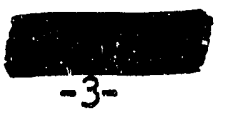

s.

i. is 


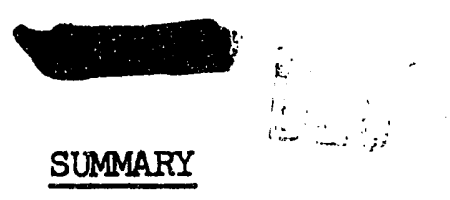

HW- 6983.5

RESEARCH AND ENGINEERING

During this period rupture control considerations restricted the power levels at all but $B$ and $D$ Reactors. At $B$ and $D$ Reactors the power levels were restricted by bulk outlet temperature limits. Flattening efficiency generally decreased as more reastors reached bulk outlet temperature limits with the rising inlet temperature.

The high-alum treatment of process water to reduce reactor effluent activity was initiated at.F Area in May. Alum feed rates were gradually Increased to $18 \mathrm{ppm}$ and although water is difficuit to treat during this period, good water quality has been maintained with no reduction in flow to the reactor.

The second column of overbore.size self-supported fuel was discharged from C Reactor at an exposure of $402 \mathrm{MWD} / \mathrm{T}$ (goal 400). Under visual examination the general appesrance was good with nothing unusual noted. Performance for the 20 columns in the test continues to be satisfactory.

Projection fuel testing at D Reactor currently 1nvolves about 1120 columns of bumper elements and about 200 columns have already been discharged without incident.

A 250-tube block of E-N material was charged into H Reactor. Reactivity balances during a period of approximately 11 days' operation at equilibrium showed that the E-N loading reactivity is close to the predicted value.

A thermocouple train, including an instrumented zircaloy-jacketed fuel rod to measure temperature effects of crud fllm deposition on fuel heat transfer surfaces, was charged Into KRR-I Loop and discharged almost Immediately due to failure of the thermocouple element. Five NINI elements in KRR-2 Ioop and four KSE3 elements in KIR-3 Loop have reached exposures of $1060 \mathrm{MWD} / \mathrm{T}$ and $3370 \mathrm{MWD} / \mathrm{T}$, respectively. KGR-4 Loop was discharged on May 11 and left empty to permit Project CGI-8.39 modification work to be started.

\section{MANUFACTURING}

\section{Production}

Reactor input production (MWD) was $0.1 \%$ below forecast. Production at the six old reactors was $6.2 \%$ below forecast and at the $K^{2} s 8.3 \%$ above.

Over-all time operated efficiency was $77.0 \%$ ( $81.7 \%$ forecast), $73.8 \%$ at the six old reactors and $86,9 \%$ at the $K ' s$. Efficlency was low at the six old reactors due to tube replacement and faulty front and rear face hardware.

There was no increase in the combined reactor instantaneous power level or the individual reactor record power levels.

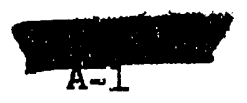


Three ruptures, two I\&E regulsr and one I\&E enrlched were removed from the reactors. The two regular metal ruptures were at $B$ and the enriched at DR. This represents the best rupture experience since September, 1960, and is significantly lower than the monthly average of 10 during the first four months of 1961

Charging of the E-N demonstration load in $\mathrm{H}$ Reactor was completed.

\section{Engineering}

Sample snap rings were removed from the front face gunbarrels at the $K$ Reactors and metallurgically examined. Approximately $85 \%$ of the carbonsteel rings exhibited stress corrosion cracks to a depth of $95 \%$ of the metal. The shear strength of the remaining metal thickness is adequate at this time.

A new cast lug ring which fits both front and rear nozzles of all reactors has been adopted by the Plants and w1ll be stocked in Spare Parts.

The deadline date of June I, 1961 for having the new Flux Monitor-Pressure Monitor Interlock System in operation will not be extended. A temporary BulkOutlet Temperature-Pressure Monitor Interlock will be used until the original project can be completed.

\section{FACILITIES ENGINEERING}

Arrangement and detail drawlings for two concepts of overslzed process tube assemblies for use in future overbored fuel channels at 105-C Reactor have been completed and requisitions for this material have been placed. Work is in progress on the design of tools for installation and removal of these assemblies. Results of preliminary studies supporting the program indicate that helium composition must not exceed 50\%, that boring tolerances of 25 mils or greater above nominal tube O.D. have slight affect on graphite temperature and that coring should range 200 to $300 \mathrm{mils}$ and extend three to elght feet beyond the gunbarrel both front and rear.

Detail design for Project CGI-883 which has fallen 5\% behind schedule, is $94 \%$ complete. Proposals from four manufacturers for the submersible motor driven pumps for the 181-K RIver Pump House are being evaluated. Hydraulic model tests for sizing the downcomer orifice plate at 105-K Reactor have been completed and indicate the downcomer approach section may limit system capacity.

A prototype magazine charging machine for use with bumper fuel elements was successfully demonstrated for engineering review purposes. An arbitrarily established charging time of 40 seconds per tube was achleved.

A preliminary review of the BPA electrical disturbance of May 3 indicated local affect.: to $b \in$ significantly less than would have been expected in view of the fact that more than $20 \%$ of the Northwest (West Area) generation capability was dropped from the system. Within IPD, equipment operation was generally as intended by process standards.
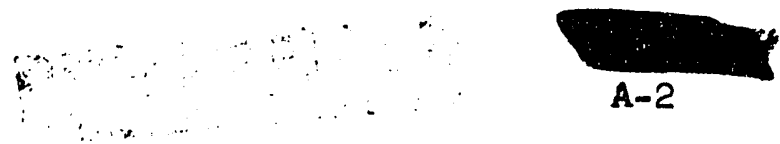


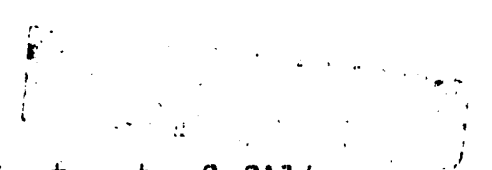

The first set of filters próvided by Project CGI-79l for removal of halogens from the reactor exhaust gases was put into operation in 100-K Area on May 26, 1961.

\section{NPR PROJECT}

Preliminary studies have been initlated to investigate parameters of advanced production reactors.

Samples of a carbon steel to zirconium coextruded joint have been recelved and evaluation tests are being planned.

Preliminary reliability studies of a secondary independent BPA supply have been instigated and changes required to the reactor for dual-purpose operation have been documented.

Comments have been prepared on the Burns and Roe, Inc. turbine-generator specification for conversion. Phase III operating parameters were modified permitting high steam pressures.

Suggested additions to first six sections of the Burns and Roe, Inc. instrumentation specifications have been provided in order to expedite the development of 109-N instrumentation scope.

Prototypes of the NPR charging machine and process channel valves are under test.

Construction on the 105-109 Building is continuing at a satisfactory rate. The roof structure over the reactor in the 105 Building is essentially in place and concrete placement has started.

The nurses' dormitory, converted for the General Electric TC facilities, has been essentially completed and the building was occupied May 29, 1961.

Processing and inspection of the zirconium process tubes is continuing at an excellent rate. Delivery of 55 tubes was received from Chase Brass. May 16, 1961 , and completes this order. Delivery of the production order remains well ahead of processing requirements.

Mock-up operation in the graphite shop was inftiated on May 17, 1961, and, as of this date, seven layers have been Installed. Production machining in the shop is proceeding although somewhat behind schedule. Delivery of graphite is essentially complete with the exception of 642 bars affected by a recent design change. Delivery of these bars will not affect machining schedules.

Work in the HUICO pipe shop is proceeding very slowly.

\section{FINANCIAI}

Contract and Accounting was advised of the closing of FY 1961 and Prior Years Budget Items 57-a-2 and 58-b-4 in a letter May 13, 1961.

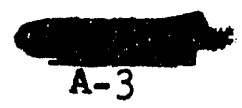


A document comparing the cost of aluminum sulphate with raw bauxite for reducing $P 32$ in reactor effluent was issued.

The annual physical inventory of coal piles by survey was completed during the period May 23-26, 1961. The inventory procedures to be used by fleld personnel were distributed.

There was $\$ 798$ paid to Department employees for suggestion awards during May, 1961. During the calendar year to date $\$ 1,766$ in awards were paid.

Coples of Mr. Cordiner's letter of April 21, 1961 announcing the establishment of an auditing program directed toward disclosure of possible violations of the anti-trust laws were distributed.

\section{RETATIONS PRACTICES}

One PhD was interviewed with no offer extended. Three ANP-Idaho Falls and Cincinnati employees have accepted offers. Four employees retired during the month.

\section{GENERAL}

\section{RESPONSIBILITY}

There was no slgnificant change in responsibility.

FORCE SUMMARY

\begin{tabular}{|c|c|c|}
\hline Exempt & $\begin{array}{c}\text { Non- } \\
\text { Exempt }\end{array}$ & Total \\
\hline 7 & 2 & 9 \\
\hline 110 & 61 & 171 \\
\hline 412 & 1351 & 1763 \\
\hline 123 & 45 & 168 \\
\hline 88 & 33 & 121 \\
\hline 16 & 14 & 30 \\
\hline 6 & 18 & 24 \\
\hline 762 & 1524 & 286 \\
\hline
\end{tabular}

\section{SAFEYTY, SECURITY AND RADIATION EXPERTIENCE}

There were 85 medical treatment injuries, 5 security violations, and no radiation exposures exceeding operational control. One disabling infury occurred in Facilities Engineering when an engineer lost the tips of the index and middle fingers of his right hand while working on a prototype charging machine. 


\section{INVENTIONS}

All persons engaged in work that might reasonably be expected to result in inventions or discoveries advise that, to the best of their knowledge and belief, no inventions or discoveries were made in the course of their work during the period covered by this report. Such persons further advise that, for the period therein covered by this report, notebook records, if any, kept in the course of their work have been examined for possible inventions or discoveries.

$A B$ Greninger :OCS :bm

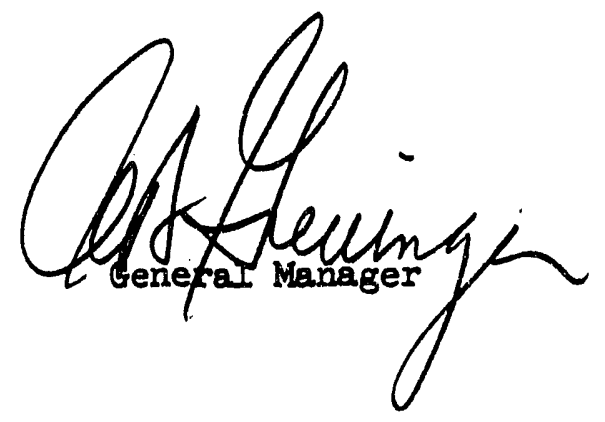




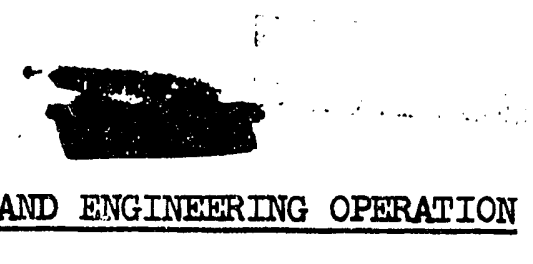

PROCESS AND REACTOR DEVELOPMENT OPERATION

\section{REACTOR FUETS}

Present Reactor Technology

Overbore Fuel Development

The second column of overbore-size fuel, CVINS in a smooth-bore zirconium tube, was discharged from tube $0954 \mathrm{C}$ on $4-30-61$ at an exposure of $402 \mathrm{MWD} / \mathrm{T}$. The tube was charged on 1-17-61 and was scheduled for a goal exposure of $400 \mathrm{MD} / \mathrm{T}$. Visual examination revealed a few isolated areas of light corrosion attack and 4 pieces with f1lm patterns; otherwise the general over-all appearance was good with nothing unusual noted. Dimensional measurements have been completed; however, they have not yet been processed through the machine program.

All twenty columns are continuing to perform satisfactorily and operating data previously reported is st1ll applicable.

Self-Supported Fuel Development

Thirty-two columns of CIVNS fuel element,s were discharged from regular C size smooth-bore zircoulum tubes at goal exposure during the report period. Nothing unusual was encountered during the discharge.

The smooth-bore aluminum test facility at B Reactor has been closed out due to excessive tube corrosion. All tubes were removed during the 5-22-6I outage.

Bumper Fuel Development

D keactor currently contains about 1015 natural uranium OIII bumper elements and 105 enrlched OII bumper elements. About 200 three-rail bumper fuel columns have been discharged without incident.

The UT-2, Fuel Core Tester, evaluation will be made using natural uranium bumper elements. In addition to evaluating the ablilty of the UT-2 tester to segregate uranium fuel cores by grain size, the test will be used to obtain additional temperature distribution data to ald in asseping ribbed process tube corrosion rates associated with three-rail bumper fuel elements.

Advanced Reactor Technology

High Tempexature Tegting - KER Facility

KRR-1:: A thermocouple train including an instrumented $\mathrm{Zr}-2$ jacketed fuel rod to measure the temperature effects of crud film deposition on fuel element heat transfer surfaces subsequent to decontamination of a carbon

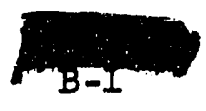




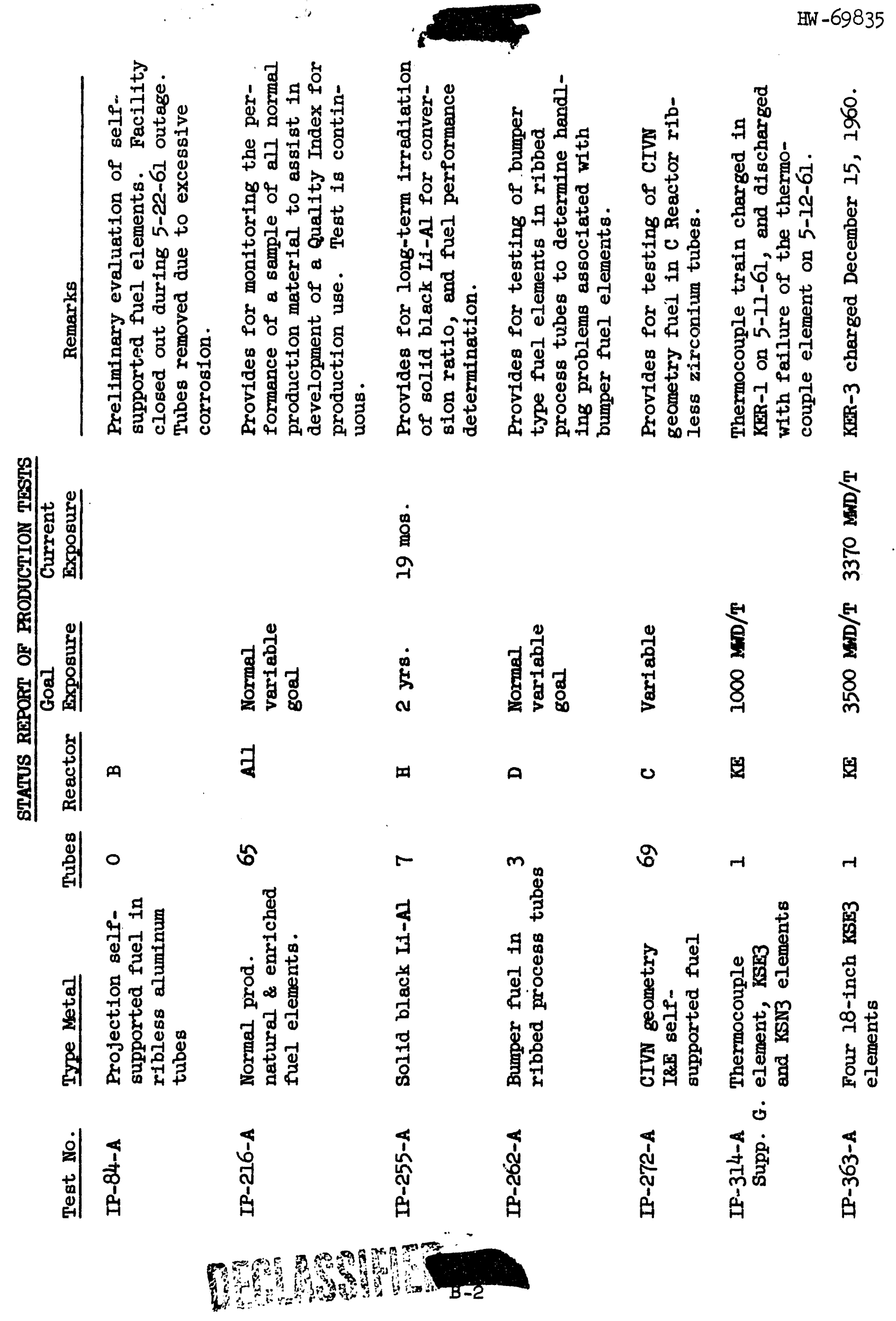



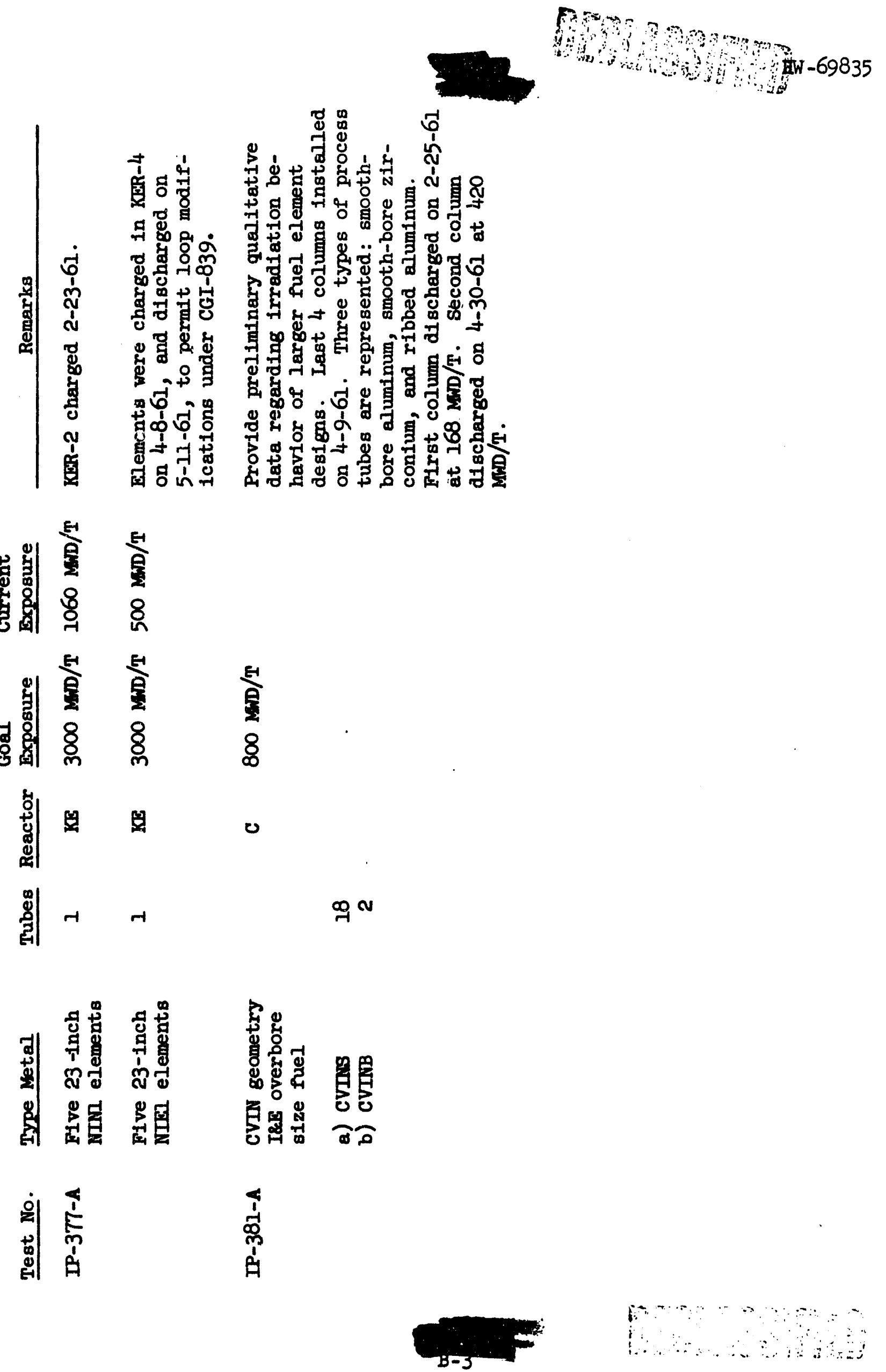
steel system was charged in KER-I on May 11, 1961. Shortly after reactor startup on May 12, 1961, the instrumented fuel element failed. The failure appears to be associated with the design of the element, although the precise mechanism of fallure is not known.

KER-2: The five NINI elements, PI-IP-377-A, in KTH-2 reached an exposure of $1060 \mathrm{MD} / \mathrm{T}$ on May 20, 1961. The irradiation continues to be uneventful.

KFR-3: The four KSE3 elements in KFR-3 resched an exposure of $3370 \mathrm{MND} / \mathrm{T}$ on May 20, 1961. These elements, which simulate the behavior of an $\mathrm{N}$ Reactor fuel element outer tube, will be discharged at the next reactor outage.

KTR-4: KKR-4 wes discharged and w1ll remain empty until after modification of the loop to permit irradiation of full sized if Reactor fuel elements.

The falled element in the charge of $\pi$ Reactor Inner fuel tubes that was discharged from KKAR-4 on April 8, 2961, has been identified as the NIFI. element at an exposure of $270 \mathrm{MD} / \mathrm{T}$. The element has been sut to the Radiometallurgy Laboratory to determine the site and natur. il fallure.

Nomenclature: (KSE3 - KFR sized single tube enriched pleces. (IIII - NPR sized inner tubes - natural urantum.) (IIIE - IIPR sized Inner tubes - enriched uranium.)

REACTOR ENGTHEGTRIMG

Present Reactor Technology

C Overbore Tubes

Reactive Metals Inc., Files, Ohto is fabricating Rircaloy process tubes in the C overbore size. Following miscellaneous process difficulties, two extrusions were tube reduced. The resulting tubes, on a preliminary examination, appear to be satisfactory. The remaining extrusions are to be tube reduced and shipped as early as possible. A second order was placed the week of May 15 for a minimum of 40 tubes. Actual work on the order began on May 3 when billet preparation and extrusion tooling work was begun. The new extrusion tooling will permit a larger bloom size thus permitting greater diameter reduction in the tube reducing step.

Advanced Reactor Technology

Specifications for ITR Process Tubes

The chemical composition specifications for the IFR Zircaloy process tubes were altered to permit a silicon concentration of up to 250 parts per million. The former specification for silicon was $100 \mathrm{ppm}$.

Technical Manual

Work continues on the preparation of a Technical Manual for IPR. Detalled outlines of system descriptions have been recelved and reviewed.

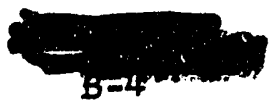




\section{$\sim$}

HW -69835

Technical Bases For Standards

Preparation of material which will serve as the technical bases for the Process Standards for NPR operation has begun. This effort will be a continuing one until after the startup of the reactor.

\section{NPR Hazards Revlew}

An outline of the NPR Hazards Review has been prepared. The report will incorporate, in updated form, the miscellaneous hazards studies which have been produced over the past months, glus the added material necessary to produce a complete summary report.

\section{REACTOR PHYSICS}

Present Reactor Technology

Pu240 Calculations

The probable imposition of a specification on Pu240 has led to some calculations of Pu240 buildup rates - particularly for the case of the overbore geometry proposed for $C$ Reactor. The following conclusions can be drawn from the calculations:

a. The pile average Pu240 from C Reactor for $800 \mathrm{MND} / \mathrm{T}$ goel exposure and $440 \mathrm{C}$ average graphite temperature with current enrichment level is calculated to be $6.5 \%$. For the same conditions in the overbore geometry, the same calculations indicate the Pu240 concentration would be $6.2 \%$. The total Pua 40 plus Pu24l would remain the same, about $7.2 \%$.

b. Cross checks of calculations (Flex I Program) with measured Pu240 concentrations at $800 \mathrm{MND} / \mathrm{T}$ for $\mathrm{H}$ Reactor and for $\mathrm{K}$ Reactors show excellent agreement.

c. The slope of the Pu240 versus average graphite temperature curve at about $800 \mathrm{MND} / \mathrm{T}$ shows that varying the graphite temperature by $100 \mathrm{C}$ produces a change in Pu240 concentration of about $0.4 \%$.

\section{Speed of Control}

First runs were completed of the spatially dependent speed-or-control calculations. These computations are deslgned to investigate cases in which the safety control system is only partially effective. Preliminery results show that in normal equilibrium pile conditions, the fallure of two adjacent VSR's does not cause the speed-of-control criterion to be exceeded. As the conditions assumed become more severe the situation becomes less clear cut and further investigation is planned. It appears that the current restriction which prohibits having two adjacent rods out of service is satisfactory.

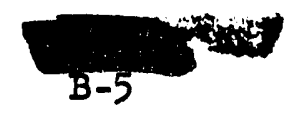


E-N Load

The initial loading at $\mathrm{H}$ Reactor showed that the reactivity obtalned was close to the predicted value. The physics calculations for the $E-N$ Load have been completed and appear in BW-69566 - "Physics of E-N Loed Compared to Natural Uranium Load at H Reactor", by D. I. Monnie, dated 5-11-61, Secret.

Np238 And Pu238 Buildup

The AEC sometime ago requested $\mathrm{Np} 238$ and Pu238 1sotopic compositions as a function of exposure in the Hanford reactors. The calculations have recently been redone, correcting a small error in the enriched fuel cases and further ccmparing the theoretical results with measured values now avallable from the twelve two-ton batch conversion ratio tests. The original reason for the AEC request was to provide information for the non-rep plutonium program, 1.e., can the exposure of fuel be back-calculated from the Pu238 composition in plutonium from the irradiated fuel. One can conclude that it should not be possible to back-calculate exposure from Pu238 composition, since it is not possible to correctly calculate the Pu238 from the exposure directly. For example, compare the following cases for natural uranium fuel.

Prposure
445
$465 \mathrm{ND} / \mathrm{T}$
$405 \mathrm{ND} / \mathrm{T}$
$800 \mathrm{MD} / \mathrm{T}$
$830 \mathrm{MN} / \mathrm{T}$

(a) H Reactor

(b) K Reactor

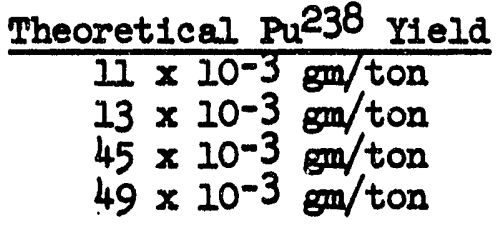

$11 \times 10^{-3} \mathrm{gm} /$ ton

$13 \times 10-3 \mathrm{gm} /$ ton

$49 \times 10^{-3} \mathrm{gm} /$ ton
Measured Pu238 Yield.

$15 \times 10^{-3} \mathrm{Bm} /$ ton (a)

$22 \times 10-3 \mathrm{gm} /$ ton (b)

$79 \times 10-3 \mathrm{gm} /$ ton $(\mathrm{a})$

$88 \times 10^{-3} \mathrm{gm} / \mathrm{ton}(\mathrm{b})$

Fractional Heat Generation Rates After Shutdown

The fraction of the heat generated after shutdown which appears in the moderator has been recalculated recently. The early calculations indicated a much higher escape to the graphite than do the updated results. Absorption of radiation which escapes the fuel is almost completely confined to the graphite - coolant water, and process tubes absorb less than $3 \%$ as much as does the graphite. Time-dependent curves covering the range from $10^{2}$ to 107 seconds after shutdown have been calculated and appear in HW-68628. "Fractional Heat Generation Rates in Hanford Reactors After shutdown", R.Nilson and R. H. Melchle, dated 5-17-61, Secret. Results are avallable for solid slugs, for present I\&W geometries and for overbore size I\&E slugs.

Advanced Reactor Technology

Doppler Transient - NPR

Test results from Hanford Laboratories work in the PCIR have been used to compute a Doppler transient to be expected in the NPR. The relation obtained is:

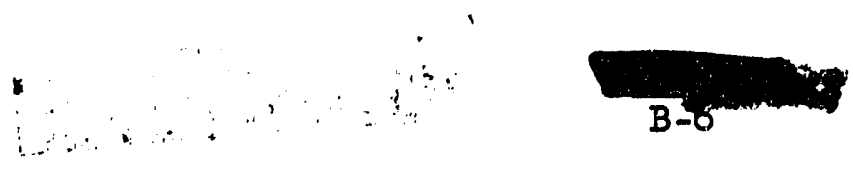




$$
\frac{\Delta k}{k}=1.24 \times 105 \quad\left\{P_{0} \Delta T\right\}
$$

when $P_{0}=$ wet lattice resonance escape probability

$\Delta \mathrm{T}=$ temperature change

$\because$

Using the experimental value of $B_{0}=0.829$, the Doppler transient is computed to be $\sim 5 \mathrm{mk}$ at half power and $\sim 8.4 \mathrm{mk}$ at full power.

\section{RADIOLOGICAL ENGINTHERING}

Radiation Control Experience

The following table sumarizes the radiation exposure experience of critical IPD classifications for the first 16 weeks of the 1961 badge year:

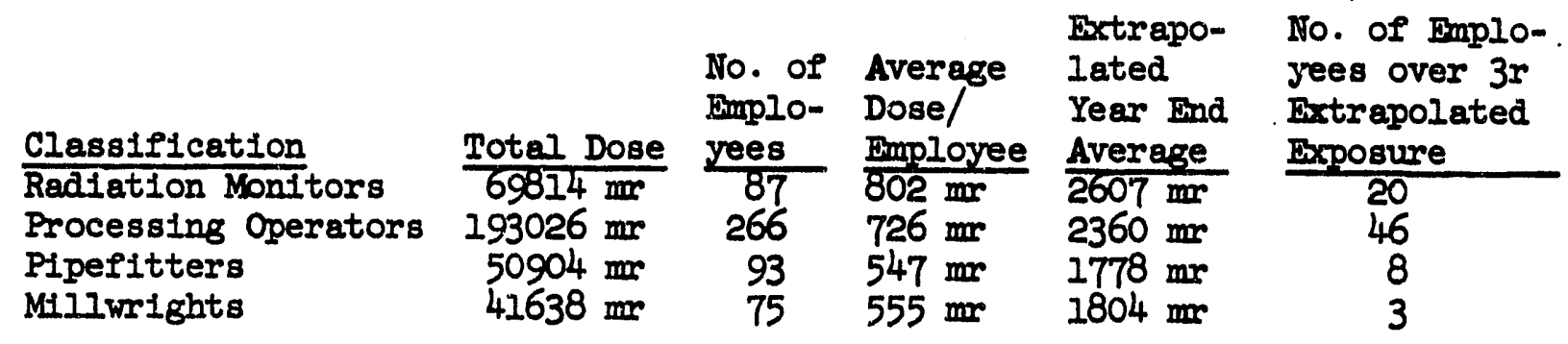

Lapse of Control

Lapse of Radiation Control D1stribution by Reactor and Component

Processing

Maintenance

Supplemental Crews

Power

Research \& Engineering

Facilities Englneering

Central Maintenance

Reactor Areas

Assigned totals

\begin{tabular}{ccccccccc} 
B & C & D & DR & F & H & KE & KW & IPD Totals \\
\hline 2 & 0 & 1 & 1 & 0 & 1 & 1 & 1 & 7 \\
0 & 0 & 0 & 0 & 0 & 0 & 0 & 1 & 1 \\
0 & 0 & 0 & 1 & 0 & 0 & 0 & 0 & 1 \\
0 & 0 & 0 & 0 & 0 & 0 & 0 & 0 & 0 \\
0 & 1 & 0 & 0 & 0 & 0 & 0 & 0 & 1 \\
0 & 0 & 0 & 0 & 0 & 0 & 0 & 0 & 0 \\
1 & 0 & 1 & 0 & 0 & 0 & 1 & 0 & 3 \\
4 & 1 & 2 & 2 & 1 & 3 & 3 & 3 & 19
\end{tabular}

Vertical columns do not necessarily add up to the indicated totals, because In some cases, a Lapse of Control may be chargeable to more than one component. Average Concentration of Radiolsotopes in Reactor Effluent Water

The average concentrations of radioisotopes in reactor effluent water from samples taken during April, 1961 are given. Concentration is in units of (10-12 curles per cc).

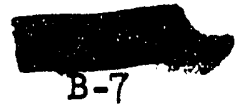




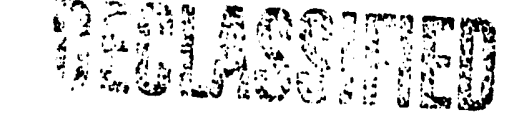

\begin{tabular}{|c|c|c|c|c|c|}
\hline Reactor & As 76 & $\underline{\mathrm{P}} 32$ & $2 n 65$ & $\mathrm{~Np} 239$ & $\mathrm{Cr} 51$ \\
\hline$B$ & 140 & 20 & 50 & 73 & 250 \\
\hline C & 270 & 54 & 250 & 160 & 320 \\
\hline D & 180 & 23 & 36 & 140 & 38 \\
\hline $\mathrm{DR}$ & 140 & 20 & 34 & 100 & 460 \\
\hline $\mathrm{F}$ & 240 & 26 & 130 & 75 & 800 \\
\hline H & 210 & 23 & 130 & 100 & 670 \\
\hline $\mathrm{KE}$ & 130 & 21 & 44 & 52 & 240 \\
\hline KW & 160 & 18 & 30 & 80 & 240 \\
\hline
\end{tabular}

HW -69835

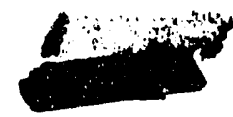

\section{-69835}

Reactor Effluent Activity Reduction

A water treatment process simllar to that tested at 100-B Area last fall was adopted at 100-F Area beginning May 1 . Anolyses of reactor effluent water indicated no improvement during the first two weeks while the alum feed rates were being gradually increased and adjustments were being made on filter runs and filter ald feed rates. Samples taken at the end of three weeks have not been analyzed, but all other indications including monitor chamber readings over the retention basins are that the effluent activity is being reduced by a considerable amount. Development of a prototype control instrument to continuously monttor arsenic-76 in reactor effluent water is progressing.

\section{Identification of NPR Fuel Element Fallure}

Assistance was given the Reactor Fuels Unit in the Identification of a ruptured IPR fuel element discharged from a KHR loop. The loop was discharged when the monitor indicated a fuel element fallure, but the element whlch failed could not be visually identifled. The method devised involved passing argon gas over the fuel elements individually and through an activated charcoal filter. The filter sample collected for the element which failed showed a high GM count. Presence of flssion product in the filter shown by a multi-channel analyzer confirmed the identification. 


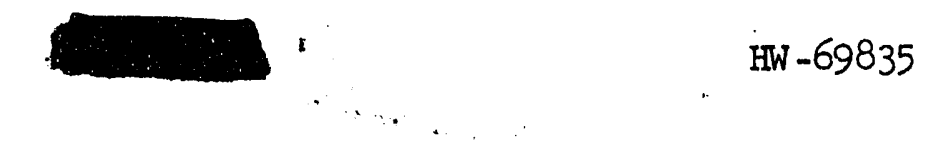

PROCESS TEECHNOLOGY OPERATION

REACTOR POWER IEVEL LTMITATIONS

During this report period the power levels at all reactors, except $B$ and $D$ Reactors, were restricted by rupture control considerations. Power levels at $B$ and $D$ Reactors were restricted by bulk outlet temperature conditions.

\section{PROCESS STANDARDS}

HW -46000 B, Process Stanüards - Reactor

Two revised standards were issued during the month. These were:

Process Standard C-030 - "Flux Monitors"

Flux monitor amplifier readings for shutdown and cold startup conditions are presently specified to be within the range of 3 to 30 per cent of the fullscale reading. The low-trip specification, in confunction with the minimum amplifier reading requirement, is designed to trip the flux-monttor controller in the event of instrument failure. The maximun amplifler reading specification was required to show sufficient chart trace of reactor flux behavior before reaching full scale. The proposed revision to the standard establishes an upper amplifier reading limit of 80 per cent of full-scale reading. This was done to minimize the amount of neutron chamber relocation that is sometimes necessary in order to meet both the operating and shutdown amplifier reading specifications. Twenty per cent of the chart is deemed ample span to record neutron flux patterns.

Process Standard D-030 - "Emergency Conditions"

A section of the standard was up-dated to refer to the proper equipment standard for stuck slug discharge requirements.

\section{HW $-46000 \mathrm{D}$, Process Standards - Reactor}

One revised standard was issued during the month. This was:

Process Standard D-030 - "Emergency Conditions"

Revisions to this standard are identical to those made for $\mathrm{BN}-46000 \mathrm{~B}$, above.

HW-46000 F and H, Process Standards - Reactor

Three revised standards were issued during the montih. These were:

Process Standard C-030 - "Flux Monitors"

Process Standard D-030 - "Emergency Procedures"

Revisions to these standards are identical to those made for $\mathrm{HW}-46000 \mathrm{~B}$, above.

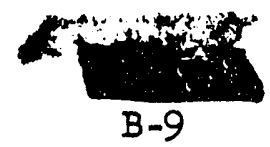


Process Standard F-01I - "Process Materlals"

Revisions to this standard consisted of the addition of oV and OV water-mixer fuel elements to the list of approved material that may be charged into the reactor. These fuel elements are four-inch I\&E material with the dimensions of 0-III fuel elements except for the length.

HW $-46000 \mathrm{~K}$, Process Standards - Reactor

\section{Process Standard A-050 - "Panellit System Control"}

Specifications for Panellit low trip and minimum operating pressures were up-dated for five-pump operation. This was necessary as a result of recent orifice changes.

In addition to the venturi and orifice factors included in the revision to the five-pump operation section of this standard, the former low-trip limit curves were replaced with simple equations as are presently employed in limit determination for six-pump operation. This change standardizes the method of limit presentation for both five- and six-pump configurations.

Process Standard C-100 - "Inoperable Rods - Ball Hoppers and Rod TestIng During Outages"

Testing of one horizontal control rod is currently permissible in the above process standard, when the reactivity status of the reactor is known to meet the sub-criticality requirements specified in another standard.

An additional alternative was provided when horizontal control rod removal is desirable without consultation with the Reactor Fhysicist. Three po1son splines shall be charged into the near slde enrichment pattern, no further than one lattice unit from an enriched charge and as close to the rod channel for the rod to be tested, as possible.

Process Standard C-030 - "Flux Monitors"

Process Standard D-030 - "Emergency Conditions"

Revisions to these standards are Identical to those made for $\mathrm{BW}-46000 \mathrm{~B}$, above. HW-27155 RevI, Process Standards - Water Plant

Two revised standards were issued during the month. These were:

Process Standard 190-B-090 - "Bmergency Water Requirements"

Numerous revisions were made to this standard. These were:

1. Backup requirements for low and high pressure crosstle lines (formerly specifled in Water Plant Standard 190-B-100), were included in this standard.

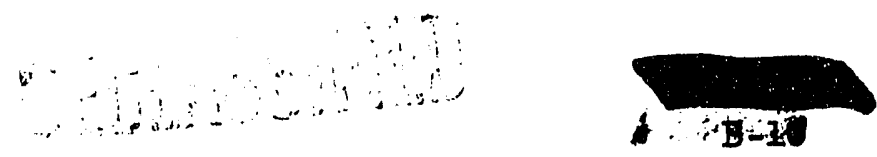



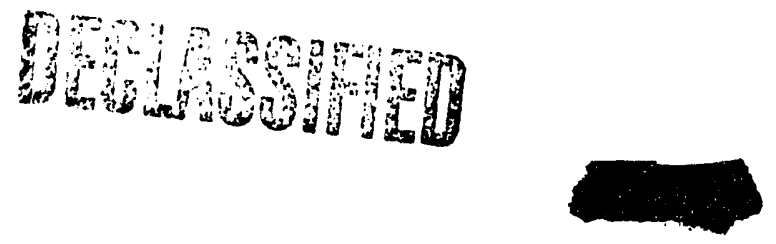

HW -69835

2. During flush of the high pressure crosstle line, it is now specified that the system be immediately returned to normal in the event of BPA failure.

3. The number of service water pumps required for emergency backup during reactor operation was increased from two to three to ensure higher flow rates through the crosstie systems.

4. Minimum shutdown riser pressures required for bolling suppression were included in the revision.

5. Walting periods before reducing the number of pumps in service and before reducing the available emergency backup were specified (Information duplicated in HW-46000, Process Standard A-030).

Process Standard 190-B-100 - "Fmergency Blectrical Requirements"

Generator switching procedures were altered and maximum operating load limits were specifled to increase the system reliability. Generator operating limits are presented in Figure 1 of this revision.

Provision was made for reducing the number of low-lift pumps to be backed up by generator power after Project CG-883 increases the low-lift flow rates and ralses their motor loads. Dropping two of the six modifled pumps from generator-powered busses upon BPA power fallure will be necessary to keep emergency loads within generator capacity.

Two requirements, inferred in the present standard, were clarified as follows:

1. During shutdown, generators on backup duty must be in a state of readiness equal to that required during reactor operation, and

2. Ioss of a generator, leaving only one in service during shutdown, requires the same personnel notifications and crosstie backup as that stated for deliberate reductions to one generator.

PROCESS CHANGE AUTHORIZATIONS

Eleven Process Change Authorizations were issued during the month to permit temporary deviation from Process Standards - Reactor, HN-46000, and one Process Change Authorization was issued to permit temporary deviation from Process Standards Water Plant, HW-27155 RevI. The se were:

PCA \#I-2l - "Spline Insertion Monitoring - KR Reactor"

Process Standard C-120 requires continuous monitoring of the outlet water temperature of a process tube recelving a spline. It further requires that if an increase or no change in outlet water temperature is observed when at least elght feet of spline has been Inserted under the active zone charge, the splining operation shall be stopped.

The present standard was wrltten for spline insertion during equilibrium operation. A reduction in non-equilibrium production losses can be obtained

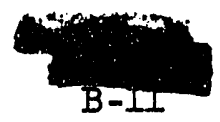



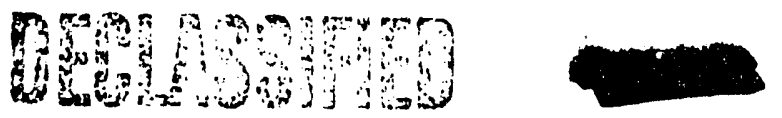

HW -69835

during reactor startup from a minimum outage if splines can be inserted during the period of time prior to receiving a significant temperature indication or when the temperature effect due to spline insertion could possibly be masked by rod movements.

Ihis process change authorized, unt1l April 28, 1961, or until the standard is revised, insertion of splines under operating conditions such that the temperature decrease due to spline insertion may not be detected provided:

1. Tube temperatures (temperature maps are acceptable) and flows are surveyed for evidence that the splines are properly inserted.

2. When both temperature and pressure indicate that a spline is not properly positioned, the outlet temperature and flow on that tube will be monitored hourly.

3. The reactor will be shut down upon any unexplained temperature change or unexplained pressure increase of 10 psi or greater.

PCA \#1-22 - "Ball 3X Functional Testing - KW Reactor"

Process Standard C-110 specifles the operability of the ball $3 X$ system must be tested annually. An important part of this test requires operation of the hopper gates and dropping the balls of the inner hoppers into the reactor.

Recent testing of ball $3 \mathrm{X}$ hoppers at $\mathrm{KR}$ and $\mathrm{C}$ Reactors by dropping of the balls into the reactor has resulted in the loss of balls in the reactor moderator. Ioss of balls in the moderator results in a reactivity decrease in the region where the balls are lodged. Reactivity loss can result in increasing (1) enrichment requirements, and (2) the reactor's rupture potential due to flux peaking in other regions of the reactor. The accumlation of $3 \mathrm{X}$ balls in rod channels has also resulted in horizontal control rod operating difficulties.

This PCA, which expires on KW Reactor's first minimum outage following July 17, 1961, permits ball 3X hopper testing under methods listed below which meet the intent of the standard.

1. All balls must be removed from the hopper. A visual check of the balls should be made to ensure that the balls are not misty or clustered. The balls must be dry and clean when returned to the hopper (followlng the testing of the hopper gate).

2. When the hopper gate is tripped, after the hopper is empty, the spring tension of the hopper gate trip mechanism must be measured. The force necessary to start the rising stem of the hopper gate downward should be approximately 750 inch pounds.

3. The ball valves at the bottom of the channel should be observed to ensure they are closed properly.

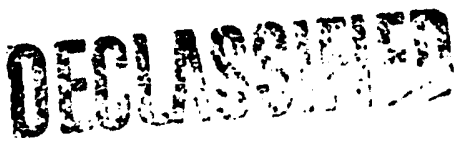




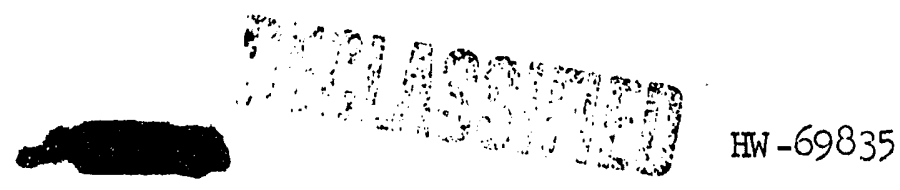

4. A determination must be made to ensure that the hopper gate passage is clear of obstructions.

PCA \#I-23 - "Ball 3X Functionel Testing - C Reactor"

Provisions for testing ball $3 X$ hoppers at $C$ Reactor are identical to those stipulated above for KR Reactor. In addition to the conditions specified for KI Reactor, it is necessary that the number of ball 3X hoppers considered available to meet total control be reduced by two ioppers, in the zones of maximum enrichment. This precaution was taken due to the time interval since some C Reactor hoppers have been tested.

PCA \#1-24 - "Horizontal Bowing Measurements - F Reactor"

Process Standard G-010 specifles that horlzontal bowing shall be measured annually in channels located on both the near and far sides of the reactor near the horizontal centerline. The purpose of these data is to monitor trends in distortion of the moderator so that adequate forewarning of potential graphite distortion problems is available.

Recent horizontal traverses at $F$ Reactor have been incomplete due to equipment limitations in severely-bowed graphite channels.

This process change authorized a delay in taking horizontal bowing measurements on process tubes or channels located on both the near and far sides of the reactor near the horizontal centerline unt1l the first outage after June 14, 1961. During this delay the Process Fngineering Operation will evaluate and improve the present procedures and equipment for taking of the se data and, If necessary, will select new traverse channels.

PCA \#1-25 - "High Pressure Crosstie Flushing - K Reactors"

Process Standard A-080 specifies that the flushing of the 105 crosstie line from $A$ and $B$ risers shall be completed using at or near normal operating pressure. Flushing of the high pressure crosstie (HPCT) line at the K Reactors has been difficult in the past due to excessive pressure differential across the flush valves.

This process change authorized, until May 18, 1961, flushing of the HPCT line from $A$ and $B$ risers with low pressire (six low-lift pumps) as a substitute for flushing with at or near normal pressure, provided the flushing flow through the HPCT line is equal or greater than the demand "emergency" flow through the line.

PCA \#1-26 - "Horizontal Bowing Measurements - DR Reactor"

Authorization was given to delay taking horizontal bowing data for simflar reasons stated in PCA \#I-24 for F Reactor.

PCA \#1-27 - "Rupture Monitoring on Crossheader \#46, D Reactor"

Process Standard D-020 specifies that the gamma monitor will normally monitor 

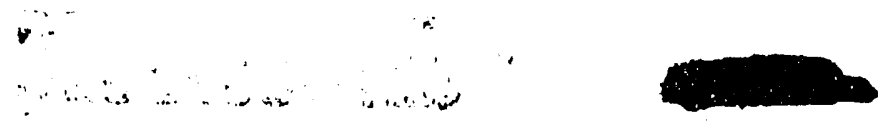

HW -69835

the crossheader effluent water activity anil that in the event of equipment failure, effluent samples shall be taken every three hours and measured for activity on all unmonitored crossheaders.

On April 17, 1961, it became impossible to meet the se requirements due to sample-line plugging on row 46. Authorlty to continue operation was given until the next outage since the likelihood of fuel element rupture occurrence at this location is remote, based on previous operating experience.

It was required that Panellit pressures of all process tubes on 46 row be monitored every hour and the riser water gamma monitor be analyzed on the same frequency for rupture debris. The reactor will be shut down on evidence of fuel element rupture from either source.

PCA \#I-28 - "Purge Material - DR Reactor"

Water Plant Standard 183-A-070 specifles the type of liatomareous earth that may be used for a process-tube purge.

Through an error in a purchase order, another grade of this material was received. The chemical composition was identical but the calcination period was shorter in the material recelved. Particle sizes are similar for both. types.

Authorization was given to purge process tubes with the "as recelved" diatamaceous earth.

PCA \#I-29 - "Water Shutoff Time - Helium Leak Testing - F Reactor"

Process Standard A-030 requires that the water shutoff times used during helium leak testing be determined from specific curves which limft slug temperatures in a drained tube to less than $170^{\circ} \mathrm{C}$. The curves specified are based on heat-generation rates following shutdown from an extended operating period.

F Reactor shut down on April 17, 1961, for leak testing and charge-discharge. After approximately a two-day outage operation was resumed, but because of continued high condensate collection, the reactor was shut down again after. approximately seven hours of operation. Leak testing of the reactor durings the second outage, using the helium-leak-detection system, would be unnecessarily delayed by requiring that curves specifled in the referenced standard be used for calculation of water-shutoff times. Calculations to determine the heat-generation rate at $F$ Reactor, considering its actual operating history preceding its last shutdown, showed that the heat output was approximately 60 per cent of that expected folloving an extended operating period.

This PCA authorized, until April 20, 1961, the use of adjusted water-shutof'f times at $F$ Reactor which will prevent the slug surface temperature on a drained tube from exceeding $170^{\circ} \mathrm{C}$.

FCA \#1-30 - "Bal1 3X system - C Reactor"

A leaking pipe cap was detected on a tee fitting in the ball $3 X$ sensing line

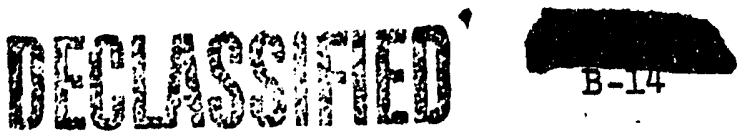




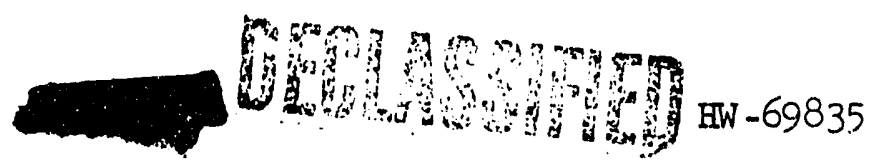

to the IP switch which actuates the time delay relay in the ball $3 x$ system. Increased leakage at this fitting could possibly result in a trip of the IP time delay relay; this would not result in a reactor scram, but could result in inadvertent by-passing of the ball $3 \mathrm{x}$ safety system.

Authorization was given for four minutes, on April 20, 1961, to by-pass the decay trip feature of the ball $3 \mathrm{x}$ safety circuit, to replace the faulty cap. The following precautions were required while the ball $3 \mathrm{X}$ system was by-passed:

1. The top-of-riser pressure must be continuously monitored. The reactor shall be scramed with the \#l safety circuit upon a reduction in TORP of 100 psi.

2. In case either low sensitivity alarm or the seismoscope is actuated and a 100 psi drop in TORP is observed, the reactor ball $3 X$ system shall be manually tripped.

PCA \#I-3I - "Water Ieak - DR Reactor"

On April 20, 1961, the water collection at DR increased slightly over that permitted in Process Standard B-010. No loss in reactivity has been observed and a survey of tube powers did not show excessive amounts of water in the moderatc:. The se datia Indicate the water leak is in the rear section of the reactor, and w1ll not signiflcantly affect reactor life.

In order to permit efficient job and manpower scheduling for the impending outage, continued operation was authorized by this process change unt11 April 24, 1961, provided the following specifications were met:

1. The dewpoint of the inlet gas to the reactor shall be maintained at less than $15 \%$ or the reactor shall be shut down.

2. Upon an indication of tube power reduction which can be attributed to water in the moderator, the reactor shall be shut down.

PCA \#1-32 - "Temperature Monitoring During Shutdown - D Reactor"

Replacement of process tube thermocouples is scheduled for D Reactor on a scale that will require approximately three or four outages. During replacement of the thermocouples, it wlll not be possible to meet tube outlet temperature monitoring specifications required during shutdown by Process Standard C-050.

To ensure that sufficient temperature monitoring is available without unduly restricting the thermocouple replacement program, the conditions given below were specified in the PCA:

1. Graphite temperatures shall be less than $100^{\circ} \mathrm{C}$.

2. Each crossheader shall have at least 10 times with operable thermocouples.

3. Hourly pressure checks shall be made on all throttled crossheaders.
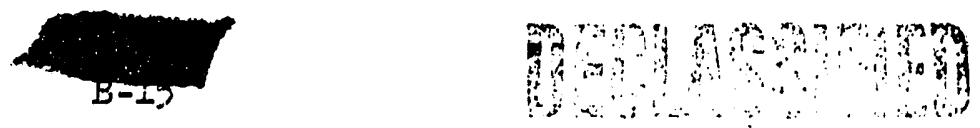
4. Crossheaders having any tube temperatures in excess of $60^{\circ} \mathrm{C}$ shall be returned to normal.

The PCA will expire September 1, 1961, or when the thermocouple replacement program is completed, whichever occurs first.

\section{PROCESS ASSISTANCE}

One engineer audited the conformance to process standards by making iffteen inspections at each reactor during the report period.

\section{RUPIURE EXPERIENCE}

\begin{tabular}{|c|c|c|c|c|c|}
\hline $\begin{array}{l}\text { Fallure } \\
\text { Date }\end{array}$ & $\begin{array}{l}\text { Tube } \\
\text { Number }\end{array}$ & $\begin{array}{l}\text { Lot } \\
\text { Number }\end{array}$ & Type of Materlal & Exposure & $\begin{array}{l}\text { Type of } \\
\text { Failure }\end{array}$ \\
\hline $\begin{array}{l}5 / 1 / 61 \\
5 / 2 / 61 \\
5 / 13 / 61\end{array}$ & $\begin{array}{l}2370-\mathrm{B} \\
1959-\mathrm{B} \\
2160-\mathrm{KAR}(I) \\
2657-\mathrm{DR}\end{array}$ & $\begin{array}{l}I Z-500-A \\
I Z-500-A \\
I P-3 I 4-A \\
K H-252-A\end{array}$ & $\begin{array}{l}\text { I\&E N } \\
\text { I\&E N } \\
\text { KSRN-2 } \\
\text { I\&E } \mathrm{B}(0.94 \%)\end{array}$ & $\begin{array}{l}491 \\
450 \\
\text { ess } \\
\operatorname{than} 1 \\
890\end{array}$ & $\begin{array}{l}\text { Side Hot-Spot } \\
\text { Unclassified } \\
\text { Unclassified } \\
\text { Jind-Male }\end{array}$ \\
\hline
\end{tabular}

\section{Iegend}

I\&E N - This is the symbol for Internally and externally cooled production reactor fuel elements of natural uranium.

KSRN-2 - This is the symbol for K Reactor single-tube fuel elements of natural uranium.

I\&E E - This. is the symbol for internally and externally cooled production reactor fuel elements with uranium cores enriched in U-235. The welght per cent U-235 in the core material is stated.

Side Hot-Spot - Failure probably caused by accelerated corrosion of the external can wall in a locallzed region of high temperature.

Unclassified - The failure did not logically fall into any of the usual types.

End-Male - Failure on the end of the fuel elements probably caused by water penetration through a weld.

\section{WATER TREAIMENT}

Alum feed rates of $18 \mathrm{ppm}$ have been accomplished at $100-\mathrm{F}$ during the month. Although water is difficult to treat during this period, good water quality has been maintained and no reduction in flow to the reactor has been required.

(I) KER IOOP I.
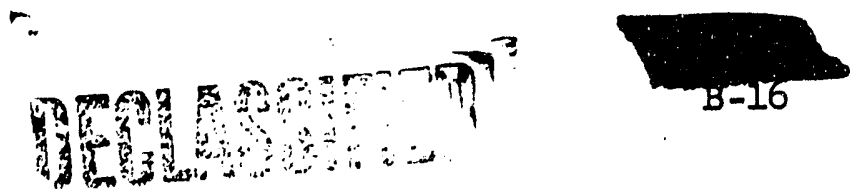


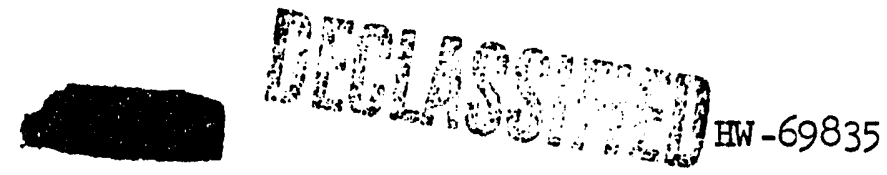

\section{OPERATIONAL PEYSICS OPERATION}

Flattening efficiency generally decreased as more of the reactors reached bulk temperature limits with the rising inlet temperature. With the lower incentive for flattening less effort was justified for equilibrium flux distribution triming. The H Reactor ECT reduction resulted as expected from the fringe blanket portion of the E-N load.

SUMMARY OF OPEERATTIY DATA OF PHYSICS INITEREST FOR THE MONTH OF MAY, 1961

\begin{tabular}{cllllllll} 
Reactor & B & C & D & DR & F & H & KT & KW \\
\hline ECT in May (1) & 1505 & 1695 & 1510 & 1530 & 1425 & 1505 & 2515 & 2570 \\
12-Month Average ECT & 1495 & 1710 & 1495 & 1550 & 1450 & 1595 & 2515 & 2520 \\
Equil. Scram Time (2) & $14-16$ & $-1-32$ & $18-21$ & $20-30$ & $14-20$ & $25-30$ & $20-25 *$ & $20-30 *$ \\
No. of Scrams and & $1 / 1$ & $2 / 2$ & $0 / 0$ & $1 / 1$ & $0 / 0$ & $2 / 2$ & $1 / 1$ & $0 / 0$ \\
Recoveries (3) & $0 / 0$ & $1 / 1$ & $0 / 0$ & $1 / 0$ & $2 / 0$ & $3 / 2$ & $0 / 0$ & $1 / 1$ \\
No. of Non-Scram & $3 / 0$ & $3 / 0$ & $1 / 0$ & $3 / 0$ & $4 / 0$ & $3 / 0$ & $2 / 0$ & $2 / 0$ \\
Outages (4) & & & & & & & & \\
Recording Period & & & & & & & & \\
$\quad$ Fram: & $4-20$ & $4-20$ & $4-20$ & $4-21$ & $4-20$ & $4-21$ & $4-21$ & $4-21$ \\
To: & $5-22$ & $5-23$ & $5-23$ & $5-21$ & $5-23$ & $5-23$ & $5-23$ & $5-23$
\end{tabular}

*Equilibrium scram recoverles are not attempted at the $K$ Reactors.

(1) Effective Central Tubes: This value 1s defined as pile power level divided by the average of the ten.most productive tubes in the reactor.

(2) This is defined as the maximum time available in minutes between scram and first indication of startup.

(3) The first pair of numbers shows the number of brief outages from which secondary cold startups would be made and the number of successful startups. The second pair shows the number of brief outages from which hot startups would be made and the number of successful recoverles.

(4) The first number shows the number of ordinary outages (including those initiated by scrams followed by unsuccessful recovery attempts), and the second shows the number of additional outages to discharge temporary poison.

\section{B Reactor - J. H. Ferguson}

Complete conversion of the 34-piece charges inside the flat zone to 32-piece loadings has permitted more efficient usage of enrichment within total control limitations and has resulted in an improved control stability and an average flattening efficiency about two per cent over that of the previous report period.

The spline coller removal system, installed during the month, permitted the use of 15 splines in addition to the PCCF system during the last startup of

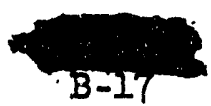


B Reactor - J. H. Ferguson (Cont'd.)

the report period; this increased flextbility, coupled with more aggressive operating techniques, resulted in a new low nonequilibrium loss of less than 0.2 equivalent day; the previous minimum nonequilibrium loss was slightly less than 0.3 equivalent day. Also installed as part of the spline coiler was the necessary shlelding for spline monltoring; four satisfactory spline traverses were subsequently obtained.

C Reactor - D. E. Newbrough

Replacement of the 10 cadmium horizontal control rods remaining from $C$ Reactor startup in 1952 was begun during the month with installation of a new boron rod in the number 7 position.

Rod calibration tests of number 1 and $13 \mathrm{HCR}^{\prime} \mathrm{s}$, whose tips reached a calculated burnout of 100 per cent during May, confirmed that the last 100 inches of the rod tips have lost reactivity strength during the last two months. Numbers 3 and 15 HCR's have reached a calculated 90 per cent burnout of the cadmium; these $4 \mathrm{HCR}^{\prime}$ 's are scheduled to be replaced, one each outage, by the end of August. The rod to be replaced will be held out of service to permit radioactivity decay during the operating period preceding its replacement. The other 5 HCR's will not exceed a calculated 90 per cent burnout, the point at which control effectiveness would be expected to start diminishing, during 1961, but are scheduled for replacement later this year.

Some control inefficlencles are expected during this replacement period, primarily from poison substitutions required for the rods temporarily being held out of service pending replacement. W1th the high sumer inlet temperatures the reactor should remain bulk-effluent-temperature-limited during the the rod replacement program.

A successful hot startup was achieved under initial conditions nearly ldentical to those existing with the hot startup attempt in April, from which a shutdown was required due to ensuing distributional heat control problems; the success of this stertup in May was the result of improved hot startup operating techniques better utilizing splines and half-rods.

With the return of number 59 VSR to service during the report period, all VSR's were in service except number 4I. All Ball $3 \mathrm{X}$ channels were also in service with the exceptions of numbers 41 and 58.

D Reactor - D. W. Constable

Smooth operation with a high flattening efficlency characterized the operation at $D$ Reactor during the report period. Only one outage occurred which was followed by nonequilibrium loss of only 0.18 equivalent day.

DR Reactor - J. F. Jaklevick

The reactivity status and control flexibility were satisfactory following initial startup with a new central block load early in the report period.

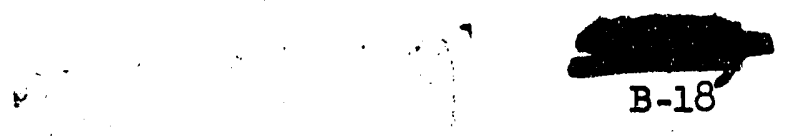



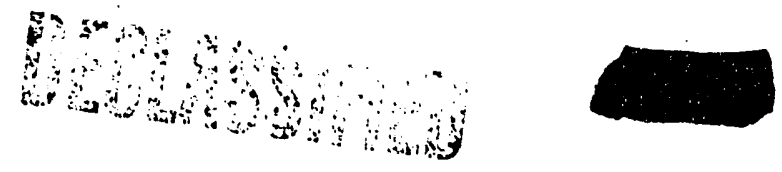

HW -69835

IR Reactor - J. F. Jaklevick (Cont'd.)

Full utilization of the graphite limit extension for the block discharge (PT IP-325-AC - Increased Graphite Limits During IR Reactivity Minimum), and an optimum amount of enrichment, resulted in sufficient excess reactivity held in the rods for efficient control during the low point in the reactivity cycle. Four PCCF tubes were returned to normal production as a result of the Initial availability of the spline system; 26 PCCF tubes remain in service. Subsequent to the outage to discharge the centril block, two outages occurred one for a water leak and one for a rupture.

\section{F Reactor - C. D. Wilkinson}

Equilibrium control hes been difficult and flattening efficiency only fair during the partial conversion from 34-piece charges to 32-piece charges and due to the loss of number $2 \mathrm{HCR}$ from service due to sticking. Number $2 \mathrm{HCR}$ will remain out of the reactor until June at which time it will be removed and inspected to determine approprlate action.

Nonequilibrium losses averaged less than 0.2 equivalent day for the four startups during the report perlod; this excellent performance was the result of Increased spline usage with the newly installed spline coller and of more aggressive startup techniques. A fallure of the Flexowriter during one startup period necessitated temporary operation at a lower power level.

H Reactor $-S$. L. Stewart

The four full-term outages plus additional short outages during the report period resulted in insufficient oporating time for efficient flattening adjustments; thus flattening efficiency was one or two per cent lower than would normally be expected. The large reactivity gain accompanying the charging of the initial $270 \mathrm{E}-\mathrm{N}$ tubes resulted in larger nonequilibrium losses. However, future operation with the spline system should prevent any significant increase In nonequilibrium losses as a result of the E-N load subsequent to the major block replacement outage.

Operation has been reasonably efficient with the full fringe poison load and with the initial 270 tubes of E-N. However, to attain optimum flattening and startup efficiencies consistently, fine flattening adjustments and slight modification of control techniques taking full advantage of the newly installed spline system will be necessary.

KE Reactor - A. R. Kosmata

Operating efficiency was generally high with only two outages interrupting continuity. Nonequilibrium losses for the two startups averaged slightly over 0.2 equivalent equilibrium day. Flattening efficiency was slightly lower than normal at the first of the report period as a result of the loss in fringe reactivity from the discharge of nearly all the remaining solid fuel elements in the fringe of the reactor (about 300 tubes). However, the flattening efficlency increased to above average values with subsequent additional enrichment
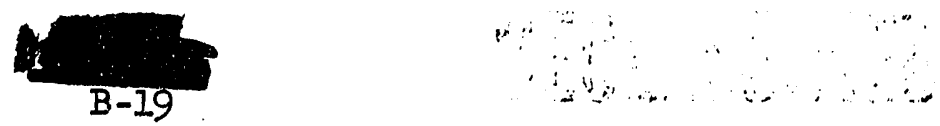
KE Reactor - A. R. Kosmata (Cont'd.)

compensation and operation at the higher maximum graphite temperatures permitted with the nitrogen-helium atmosphere (PI IP-358-AC, Replacement of Carbon Dioxide with Nitrogen As a Constituent of the K Reactor Atmosphere).

Work continued on the removal of 3X balls lodged in HCR channels 17 and 19; number 17 channel was nearly cleared. Following the drop of one channel of $3 \mathrm{X}$ balls (channel 43) some tubes in the area covered by this particular ball chanel operated about $15^{\circ}$ cooler, indicating some balls remained lodged in the lattice. This local reactivity loss will be compensated by the charging of additional enrlchment.

KW Reactor - R. A. Chitwood

Operation during the report perlod was characterized by an above average flattening efficlency; improved enrlchment placement was made possible by the increased accuracy of refinements in distributional and total reactivity accountIng in the reactor. Operating continuity was interrupted by two full outages; a successful hot startup was achieved following a scram 11 hours after one of the two inftial cold startups.

PROCESS PHYSICS STUDTES

Safety Control Studies

A production test to install experimental octant monitoring and Intermediate range instrmentation at KF Reactor 1s circulating for signatures. This test Is being carrled out jolntly with the Instrument Development Operation, Facility
Englneering Operation.

Pile Reactivity studies

Sample IBM 7090 accountability runs to apply the 2-ton batch test results have been completed. A document sumarizing the analyses and the appropriate normallzing factors is currently in the rough draft stage.

NPR startup test planning has focused during the past month on sensitivity

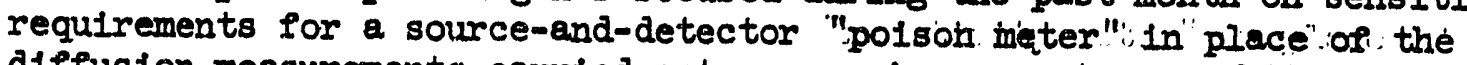
diffusion measurements carrled out on previous reactor graphite stacks.

A flux traverse analysis code written for the IBM 7090 was completed and published as HW-69486. It w11l accept as input the raw data corrected only for background from existing traversing methods. The analysis includes calculation of the individual slug factors, peaking percentage, and calculation of a relative rup-
ture potential.

Calculations of the dependence of the conversion ratio and the $P u 240$ concentration on graphite temperature for varlous fuel elements and exposures was completed. The results will be used in analyzing the effects on these parameters of possible graphite temperature elevation programs which would accompany the the replacement of carbon dioxide by nitrogen in the gas atmosphere. A short sumary of this study w1ll be documented in the near future. 
H Reactor operated for approximately 11 aquilibrium days with $250 \mathrm{E}-\mathrm{N}$ tubes charged. Reactivity balances during the period indicated that the $\mathrm{E}-\mathrm{N}$ loading reactivity is approximately as calculated. Therefore, the $\mathrm{E}$ to $\mathrm{N}$ ratio proposed in the production test was charged during the outage which ended May 28. A number of spline traverses were taken during equilibrium operation at $\mathrm{H}$. Prior to charging of the $250 \mathrm{E}-\mathrm{N}$ columns an average flux distribution in that block showed a flux peak about two per cent above a cosine and skewed four natural uranium slug lengths upstream. The flux distribution with the E-N loading has not been thoroughly analyzed but appears to show longitudinal flattening. Data analyzed for one $\mathrm{E}-\mathrm{N}$ traverse indicated a flux depeaking of about seven per cent. However this factor should be substantiated by other traverses before a definite conclusion can be reached.

In automatic control simulation tests under PT IP-383-C a 16-point recorder used with RTD's from the zone temperature system was temporarily installed. This recorder functioned satisfactorily and had a faster repeat cycle than the normal control room trend recorder which uses thermocouple signals. Initial attempts were made to determine shutdown transient parameters necessary to avold overshoot under automatic control during large power changes.

Spline samples for the flow lab testing of "weaker" splines (less poison effect) have been obtained, and testing will now begin. Thinning of splines by chemical means resulted in pitting which in turn resulted in a lower boron content for a given spline thiciness than would be realized by mechanical thinning. However, the chemically-thinned splines should be satisfactory for the intended flow tests.

Spline coilers have now been installed at $B, F$ and H Reactors, but mechanical and electrical bugs are still being eliminated. Some difficulties were experienced with spline traverses at $H$ Reactor when splines could not be inserted far enough; shutdown spline traverse data is adequate, however, with 32-foot splines. The DR and C Reactor spline coller installations are yet to be completed. The $C$ Reactor already has a reasonably effective removal technique and has shielding which permits monitoring for spline flux traverses.

\section{Shielding Studies}

The gunbarrel clearance at the $c$ Reactor has been $20 \mathrm{mils}$ on the diameter as compared to $15 \mathrm{mils}$ at the older reactors. The 40-tube block of overbore tubes planned for C Reactor Installation in August will also be biela to a 20 mil clearance rather than the 25 previously considered. Meanwhile, a progam of radiation streaming investigations 1 s planned by the HLO experimental shielding group to provide additional data concerning leakage through annuli.

\section{Reactor Fundamentals Training}

The spring sessions of Reactor Fundamentals classes for Reactor Specialists and Pile Operators were completed during the month. No Reactor Fundamentals classes for Operations personnel are planned during the summer vacation months.

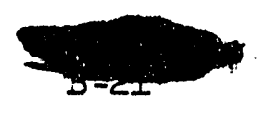


THASTING OPERATION

IRRADIATION TTESTING OPERATION

DR-1 Loop

The DR-I Ioop was operated continuously throughout the report period with the exception of 110.5 hours during reactor outages. Reference test conditions ( $1500 \mathrm{~F}$ cladding temperature) were maintained for 372 hours bringing the total time at reference conditions to 1972 hours. The test element was cycled three times from $1500 \mathrm{~F}$ to ambient temperature for a total of 13 cycles. PI IP-376-D, Supplement A, authorized extension of the WGCR-BDR-3 test throush October.

Operational testing of the No. I motor-generator set was terminated after satisfactory operation of the equipment over a two-mouth period.

The rear gas-lubricated bearing in the No. I primary loop clrculator falled due to a partial loss of the bearing gas supply. The flow of lubricating gas was reduced by the fallure ot the speed reducer bearings in one of the lubricating gas compressors.

\section{B-1 Loop}

The H-I Loop was cooled by single-pass process water during the entire report period.

\section{Sample Irradiatlons}

The following Irradiation samples were handled during the month:

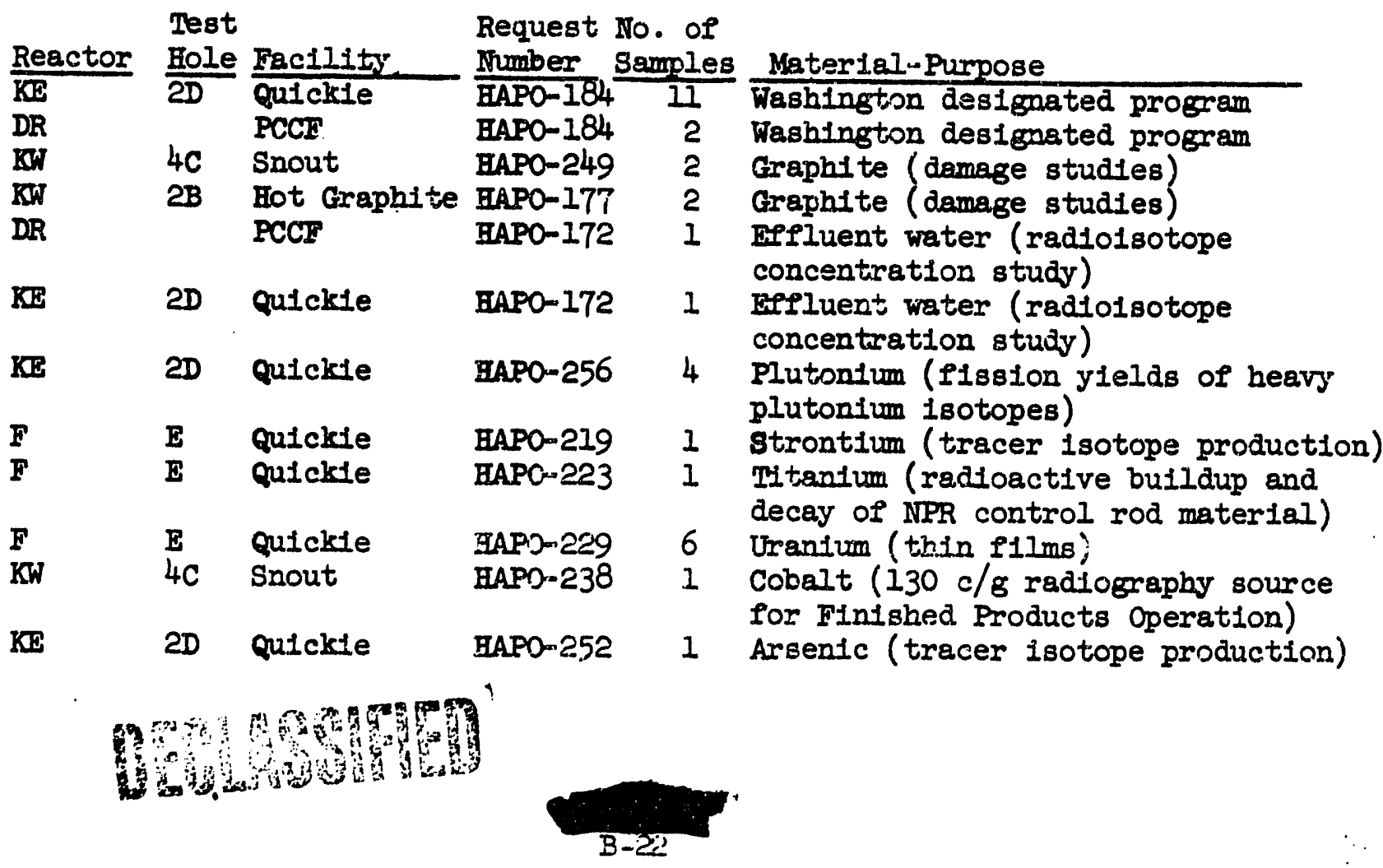




\begin{tabular}{|c|c|c|c|c|c|}
\hline Reactor & $\begin{array}{l}\text { Test } \\
\text { Hole }\end{array}$ & Facility & $\begin{array}{l}\text { Request } \\
\text { Number }\end{array}$ & $\begin{array}{l}\text { No. of } \\
\text { Samples }\end{array}$ & Material-1:urpose \\
\hline DR-H & & $\begin{array}{l}\text { PCCF } \\
\text { Gamma* } \\
\text { Gamma* }\end{array}$ & $\begin{array}{l}\text { सAPO-254 } \\
\text { НAPO- } 1171\end{array}$ & $\begin{array}{r}5 \\
13 \\
3\end{array}$ & $\begin{array}{l}\text { Arsenic-phosphorous (tracer 1sotope) } \\
\text { Plastic and rubber (damage studies) } \\
\text { Concrete (damage studies) }\end{array}$ \\
\hline
\end{tabular}

Borescoping Activities

Process Channel 1969 - F Reactor - The channel was inspected to determine why a new process tube could not be inserted. No obstruction was found in the channel. There was a four-Inch gap in the tube blocks at 21 feet, where the tube had ceased to move.

Problem Channel 0789 - F Reactor - A melted plecu of aluminum, still attached to the process tube, was observed 16-1/2 feet in from the inlet tube flange. The tube is crumpled, at six feet in from the outlet tube flange.

Problem Channel 2469 - F Reactor - The process tube 18 crumpled at 3-1/2 feet In from the outlet tube flange.

Process Channels 2778, 1879, 1578, and 2496 - B Reactor - These channels were inspected to determine why new process tubes could jot be Inserted, with results as follows:

Channel $277^{8}$ - The channel was completely blocked by small pieces of broken graphite at 24-1/2 feet in from the inlet tube flange.

Channel 1879 - Small pieces of broken graphite wexe spread along the channel to 25 feet in from the inlet tube flange. The channel was blocked by larger pieces of broken graphite at 25 feet.

Channel 1578 - Process tubing was. noted in the channel starting at 8-1/2 feet in from the inlet tube flange. The tube had not been split and was bent, preventing further inspection.

Channel 2496 - A folded piece of process tube coumpletely blocked the channel at 16 feet in from the inlet tube flange.

Process Tubes 1159 and 2478 - DR Reactor - The tubes were Inspected to explain dfficulties encountered during charging. No obstructions could be found in elther tube.

Process Channels 2880 and 1781 - H Reactor - The cheinnels were inspected to determine why new process tubes could not be inserted. The channels are both badly broken with several gaps in the tube blocks. No definite obstruction could be found in either channel which would prevent tube insertion.

Iorlzontal Control Rod Channel No. 17 - KE Reactor - The channel was inspected to determine 1 ts condition prior to a planned removal of the saddle blocks. Gaps in the filler layers and track, $3 \mathrm{X}$ balls, and raised saddle

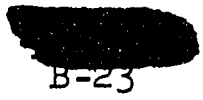




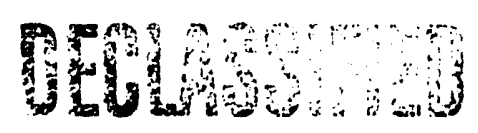

HW -69835

blocks were noted. A report of this inspection has been issued.

Process Tube 4092 - C Reactor - The tube was inspected to determine the location and extent of damage to the tube from the VSR drilling operation. A hole was found in the side of the tube approximately 1/2-inch by 1/4-inch in size.

Vertical Safety Rod Channels Nos. 58 and 41 - C Reactor - Each channel was inspected frequently during attempts to remove or re-position graphite blocks obstructing the channels.

Vertical Bowing Measurements

A summary of results of vertical bowing melasurements follows. All distances are measured from the process tube inlet flange.

\begin{tabular}{|c|c|c|c|}
\hline Date & Tube & Distance & Results \\
\hline $5-1-61$ & $4676-F$ & 36 feet & $\begin{array}{l}\text { Up .10" at } 9^{\prime 4}{ }^{\prime \prime} \text { since } 12-19-60 \\
\text { Down .06" at } 20^{\prime} \text { since } 12-19-60\end{array}$ \\
\hline $5-18-61$ & $4674-C$ & 36 feet & $\begin{array}{l}\text { Down .04" at } 8 \text { ' since } 2-27-61 \\
\text { Down .14" at } 21 \text { ' since } 2-27-61\end{array}$ \\
\hline
\end{tabular}

COOLANT TESTITV OPERATION

KFR Loop Operat1on

KGR-1 - The loop was empty from April 8 to May 11. During the outage of May 17, a thermocouple train was charged as authorized under PT IP-314-A, Supplement G. The charge consisted of a 16-inch thermocouple rod element with one KSE3 and four KSN3 alements as heaters. Approximately six hours after reactor startup, the thermocouple element ruptured scraming the reactor. The loop was discharged and remained empty for the remainder of the month.

During the outage of April 26, all front and rear face piping was replaced except the lower front and rear crossheaders whtch were replaced last December. A primary pump was replaced during the May 11 outage.

KFRR-2 - Testing of Pive 24-Inch fuel elements (NIM) w1th brazed end closures as authorized by PT IP-377-A continued throughout the month. Loop operating conditions. were $240 \mathrm{C}, 1600 \mathrm{psi}$, and $\mathrm{pH} 10$.

During the April 26 outage, the front crosisheaders, connectors, and thermocouple Y-block were replaced.

KFR-3 - Testing of four 18-inch, 1.6 per cent enrlched fuel elements (KSE3) as authorized by PT IP-363-A continued throughout the month. Loop operating conditions were $190 \mathrm{C}, 1600 \mathrm{psI}$, and $\mathrm{pH} 10$.

A reactor scram occurred on May 10 when a short circuit in the primary heat exchanger cooling water flow recorder caused a five-ampere branch circuit 


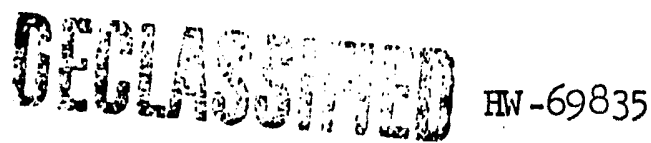

fuse to blow. One of the components fed by this circuit was the main loop flow controller which caused the flow control valve to go fully open following loss of electrical power. The reactor scram then resulted from a high flow trip.

The upper crossheader, the connectors, and the thermocouple Y-block were replaced on April 27. The lower crossheader was replaced last December.

KFR-4 - Testing of four 24-inch fuel elements (NINI) with brazed end closures and one 23-inch fuel element (NIFH) as authorized by PT IP-377-A was terminated with the discharge of the tube during the May 11 outage. The loop was left empty in anticipation of CGI-839 100p modification work. A primary pump was replaced during the month.

1706-KE Single-Pass Tube Operation

All eight tubes were supplied normal process water from 105-KE throughout the month.

KE Reactor Outage Time Requirements

Two unscheduled outages were charged to production testing for the month. A total of 28.2 hours was charged to production tests as listed below:

\section{Production Test PT IP-314-A}

PT IP-377-A

PT IP-363-A

PT IP-3I4-A

PT IP-363-A

PT IP-377-A

PT IP-314-A

Description
Charge thermocouple traln, replace
reactor face pipIng
Replace reactor face piping
Replace reactor face piping
Charge KHR-1
Instrument faIlure, KHR-3
Discharge KHR-4
Discharge rupture, KGH-1

Charge thermocouple train, replace

reactor face piping

Replace reactor face piping

Charge KIHR-1

Instrument fa1lure, KHR-3

Discharge rupture, KLRR-I

Hours

$7 \cdot 3$

3.5

3.5

5.1

5.4

.7

2.7

\section{Out-of-Reactor Facility Operation}

\section{6-KE Stngle-Pass Mock-Up Tubes}

Corrosion testing of aluminum cermets and prefilming of carbon steel coupons was discontinued on May 8 in preparation for dismantling the test facility.

ELMO-4 - The repaired pump was installed and testing resumed on May 5. Rate and mechanism of rupture testing using coextruded uranium Zircaloy-2 fuel rods continued for the remainder of the month.

ELMO-5 - Corrosion testing of Monel, Carpenter 406 stainless steel, 420 stainless steel, Hastelloy C, Zircaloy-2, and Teflon coupons continued during the month. Coupons of Allegheny Ludlum 406 stalnless steel were charged on April 27 for corrosion testing. 
ELMO-6 - Corrosion testing using a slurry of molybdenum trioxide as the corrosion inhibitor with loop water at $\mathrm{pH} 4.5$ continued. In addition to the aluminum X-8001 coupons, corrosion coupons of sensitized stainless steel and Zircaloy-2 were added to the loop. The effect of high and low coolant velocity on corrosion rates is being tested.

ELMO-7 - The following test work was continued:

1. Corrosion testing of suit-case-handle supports on two zircaloy-2 clad fuel elements.

2. Corrosion testing of one KSE.3 fuel element.

3. Fretting corrosion testing of a FRTR fuel element.

4. Corrosion testing of zircaloy-2, carbon steel, and 304 stainless steel coupons.

Prefllming of 304 stalnless steel and A-212 carbon steel coupons was. completed during the month.

ETMO-8 - LOW temperature shakedown muns began: on May 1 and continued throughout the month. Operating temperature of the loop will be limited to less than $600 \mathrm{~F}$ because of the 17-4 PH materlal used in the pump construction unt1l 316 stainless steel replacement parts are procured.

ELMO-10 - Three decontamination tests on coupons prefilmed in CEP-1 were completed. Decontamination testing continued with twenty runs completed during the month.

CEP-1 - The seventh and eighth prefilming runs were completed on samples of carbon steel, Zircaloy-2, Stellite 6 and 12 , and Haynes Alloy No. 41.

CEP-2 - The gold-plated carbon steel zircaloy-2 fretting test was terminated after 786 hours of testing. Another Iretting corrosion test to determine the effect of contact area on fretting corrosion between two Zircaloy-2 surfaces began on May 6 and continued for the remainder of the month. A miniature recording $\mathrm{pH}$ instrment was installed in the loop to evaluate 1ts accuracy, 1ts reliabllity, and its possible use in other test facilities.

CEP-3 - Work continued on rebullding the loop.

CEP-4 - Corrosion testing of aluminum, carbon steel, zircaloy-2, and stainless steel in high oxygen water was completed during the month. An oxygen analyzer was installed in the loop. Pyrex glass bearings installed in the pump did not prove satisfactory. At month's end, the loop was being conditioned for new test work.

REP-1 - Gross fission product contamination-decontamination studies were resumed on May 5. Coupons of stainless steel, carbon steel and Zircaloy-2 were prefilmed, contaminated and decontaminated. Decontaminants for this test were A solution( sodium hydroxide and potassium permanganate) and $B$ solution (sodium bisulfate).

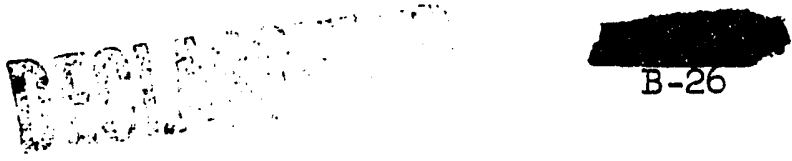




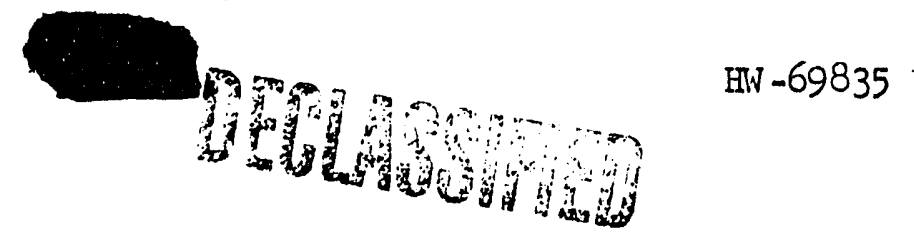

Irradiated Fuel Element Examination

Examinations were completed on fuel elements from the following 52 tubes during the month in the Metal Examination Facility (105-C).

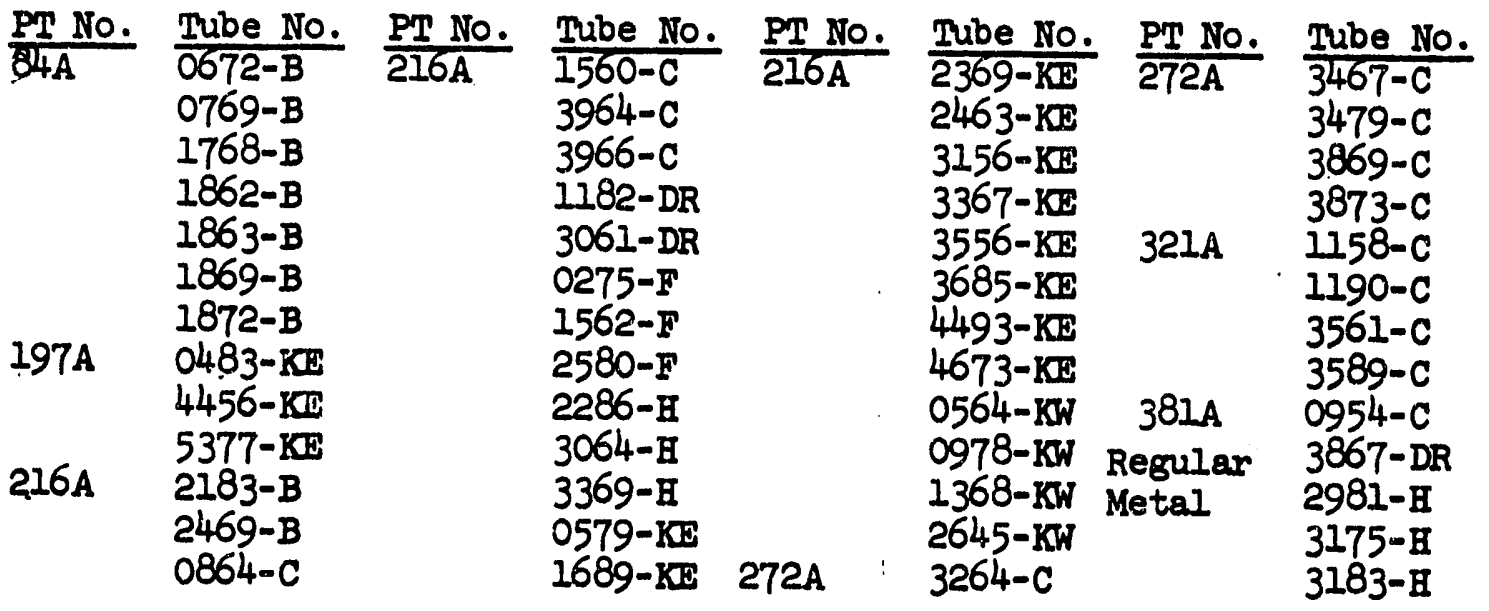

Process Tube Corrosion Monitoring Program

In-reactor measurements of 781 process tubes were completed during the month. Ilsted below are the number of itubes measured for lach reactor and the document number of each report isoued:

\begin{tabular}{crrrr} 
Reactor & No. of Tubes Probologged & Report No. & HN Number \\
\cline { 3 - 4 } F & 92 & 34 & & 69341 \\
B & 16 & 35 & 69354 \\
H & 5 & 36 & 69416 \\
DR & 531 & 37 & 69498 \\
F & 37 & 38 & 69513 \\
D & 9 & 39 & 69514 \\
C & 6 & 40 & 69529 \\
DR & 41 & 41 & 69546 \\
B & 44 & 42 & 69659
\end{tabular}

V1sual examination, wall-thickness and rib-helght measurements were completed on process tubes as follows:

\begin{tabular}{ccc} 
Reactor: & Number of Tubes & HW Number on Unclassified Report \\
\cline { 2 - 3 } D & 1 & 69340 \\
DR & 3 & 69676 \\
F & 2 & 69624 \\
H & 1 & 69418 \\
$\mathrm{KE}$ & 1 & 69417 \\
$\mathrm{KW}$ & 1 & 69569
\end{tabular}

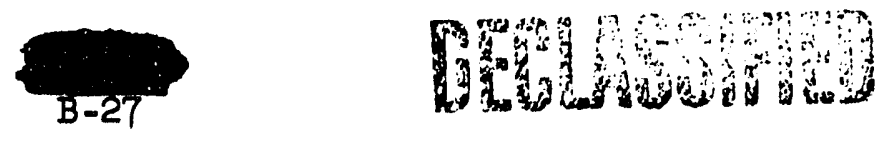


The process tubes examined from $D, D R, F$ and $H$ Reactors were removed because they were leakers. Thube $3477 \mathrm{~m} \mathrm{D}$ was the lirst tube leaker which contained bumper fuel elements. However, the appearance and location of the leak and corrosion in this tube was similar to that found in other tubes which were installed approximately the same time and subsequently leaked. There was no evidence in the tiube that the leak was caused by the bumper fuel elements.

In tubes 2576-DR, 2582-DR and 2676-DR, the leaks were found on the top half located between 9-1/2. feet and $10-1 / 2$ feet from the outlet tube flange. The leaks were caused by accelerated internal corrosion.

The tubes examined from F Reactor were 2174 and 2875. In tube 2174, the leak was caused by internal corrosion located at the $120^{\prime}$ clock pusition between $13-1 / 3$ and $13-7 / 8$ feet from the outlet tube fiange. Although tube 2875 was removed as a leaker, examination revealed no evidence of a leak.

The leaker tube examined from H Reactor was 2390. The leak was found to be a transverse crack located on the top hali, 16-1/2 feet from the outlet tube flange.

Tubes 2461-KE and 2270-KW were examined to obtain corrosion date from $K$ Reactor process tubes. Tube $2270 \mathrm{KW}$. was probologgea prior to removal. Actual wall-thlckness from this tube showed the probolog interpretation to be accurate within one $\mathrm{mi}$ ?

Panellit System Program

Gages repalred, calibrated by Malntenance Geges meeting examination criteria -previous month

In-board gage rellablility examinations Gages meeting examination criterla -previous month -average for past year

$\begin{array}{lll}- & 206 & \\ - & 178 & (86 \%) \\ - & & (77 \%) \\ & & \\ - & 1793 & \\ - & 1689 & (94 \%) \\ - & & (88 \%) \\ - & & (90 \%) \\ - & 1793 & \\ - & 1792 & (99 \%) \\ - & & (99 \%) \\ - & 10025 & \\ - & 10020 & (99.9 \%) \\ - & & (99.7 \%)\end{array}$

Response time determination

Meeting response criteria

- last two months

In-board Bourdon coll leak examinations

Non-leaking coils -average rate for past two years

Diring the mortity 170 gages received fallure analysis.

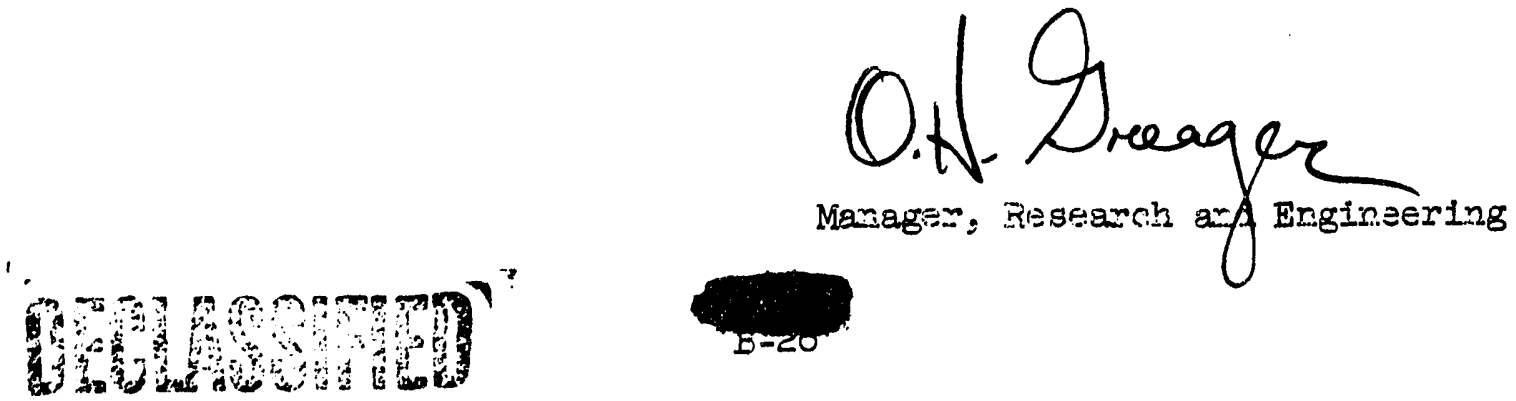


MANUFACTURING

\section{PRODUCTION OPERATION}

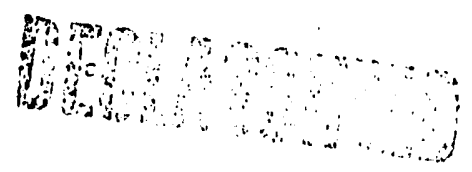

PRODUCTION PIANNING \& SCHEDULING

Discharge Concentrations

There were no discharge goal exposure adjustments effected during May. Overall exposure of uranium discharged was down significantly from previous months. Major factors contributing to this reduction include:

(1) Discharging at B Reactor to fill outage time and to correct operating problems associated with process tube leaks.

(2) Discharging at $F$ Reactor to replace tubes and to eliminate power level limitations resulting from high powered 34piece charges in the central zone of the reactor.

(3) Discharge of a block of tubes from H Reactor to charge a pilot load of enriched uranium-lithium tubes.

Discharge Exposure Comparison (MWD/T)

$\begin{array}{llll}\text { Regular Solid } & \frac{\text { Regular I\&E }}{601 \mathrm{O}} \underline{2 K^{\prime} s} & \text { Enriched I\&E } & \begin{array}{l}\text { Overall } \\ \text { Exposure }\end{array}\end{array}$

$\begin{array}{llllllll}\text { March } & 762 & 766 & 691 & 691 & 865 & 661 & 714 \\ \text { Apri1 } & 679 & 659 & 716 & 682 & 817 & 692 & 703 \\ \text { May } & 762 & 719 & 647 & 669 & 805 & 687 & 669\end{array}$

ESSENTIAL MATERIAIS

Rail and truck shipments received in May were as follows:

$$
\begin{aligned}
& \text { Carload shipments for IPD - } 172 \\
& \text { Carload shipments for other Depts. - } 138 \\
& \text { Truck shipments for IPD - } 188 \\
& \text { Total } 498
\end{aligned}
$$

\section{MISCELCANEOUS ACTIVITIES}

The first of the eleven Mfg. Training Program men scheduled into IPD this summer arrived on May 29 . He was placed in $\mathrm{KE}-\mathrm{KW}$ Maintenance Engineering for his first 6-month work assignment. Transfer-out arrangements were completed for the four MTP members who will leave IPD in June.

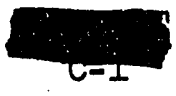


m copoln ofog of w

|a

\section{ma}

高家

in $\dot{7}$ :

ம்่

$\dot{\mathrm{o}}$

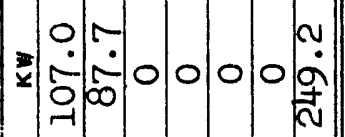

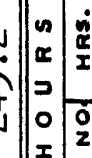

m.

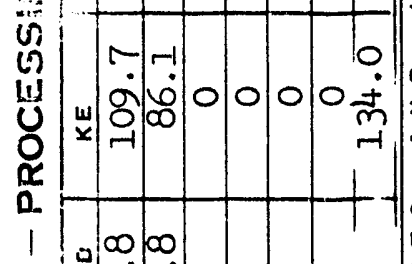

ध

는

in

in

方

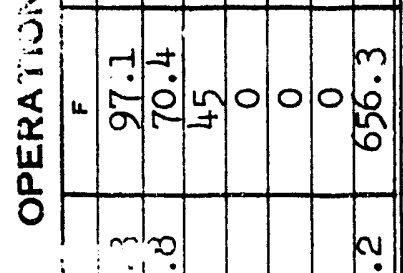

บ

崖

艾

0

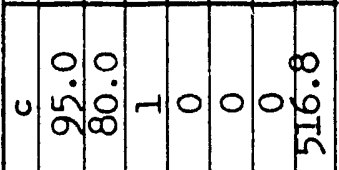

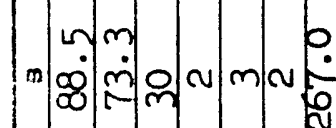

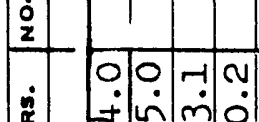

viọ

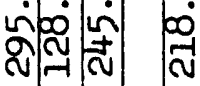

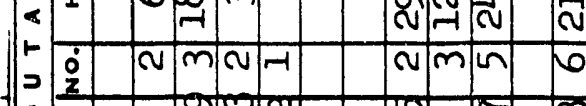

ข்่0

A

$\propto$

: 2

范

$\dot{x}$

党

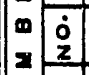

$\mathbf{2}$ z

\begin{tabular}{l}
\hline \\
0 \\
2
\end{tabular}

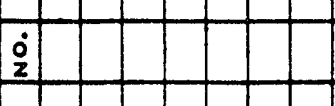

$\infty$

लें:

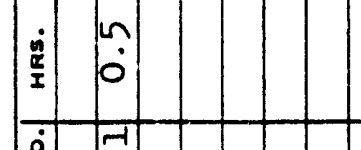

\begin{tabular}{llll}
-1 & & & \\
\hline
\end{tabular}

ल
ทे

$\checkmark$

ใ

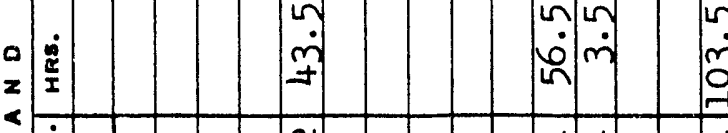

ज ले m

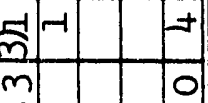

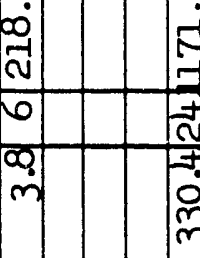

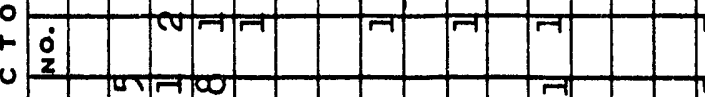

세

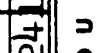

-10. $m=\eta \div \neq 9$

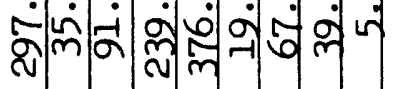

$\because \quad-0.7 r=0$.

0 1 लं

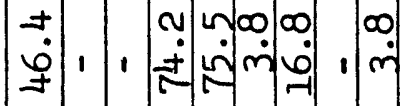

ผัญ

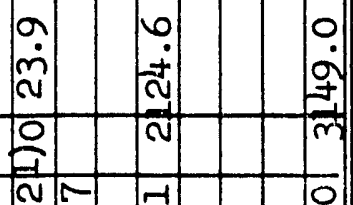

육

तो

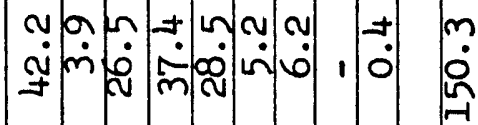

- bona a

స 1000.

-06 ortoo in 0

लें

a

r- no vor at

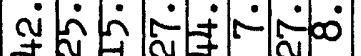

को is

ร.

')

ว

क

+

몽 -

is

"ृ

ช

54

i- 0

뭉

常

पै

窎

m

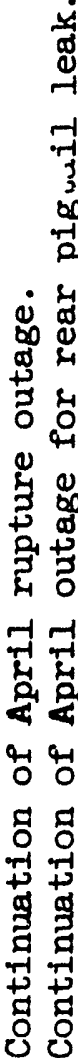

斗

祃和

装吉

ठํㅇㅇㅇ

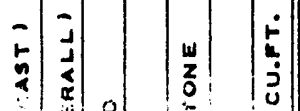

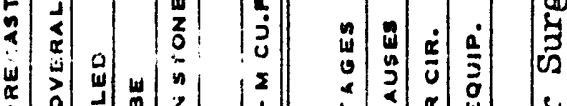

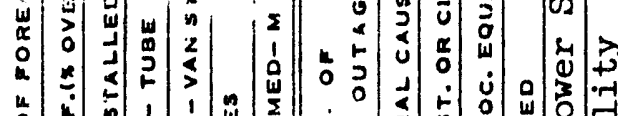

and

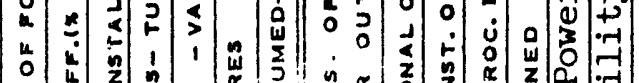

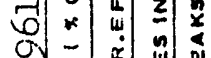

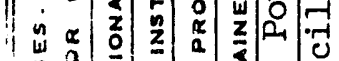

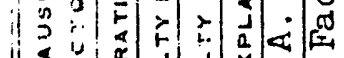

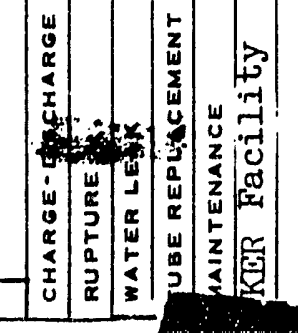

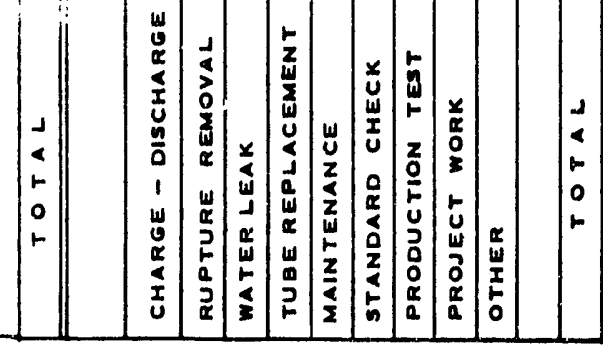




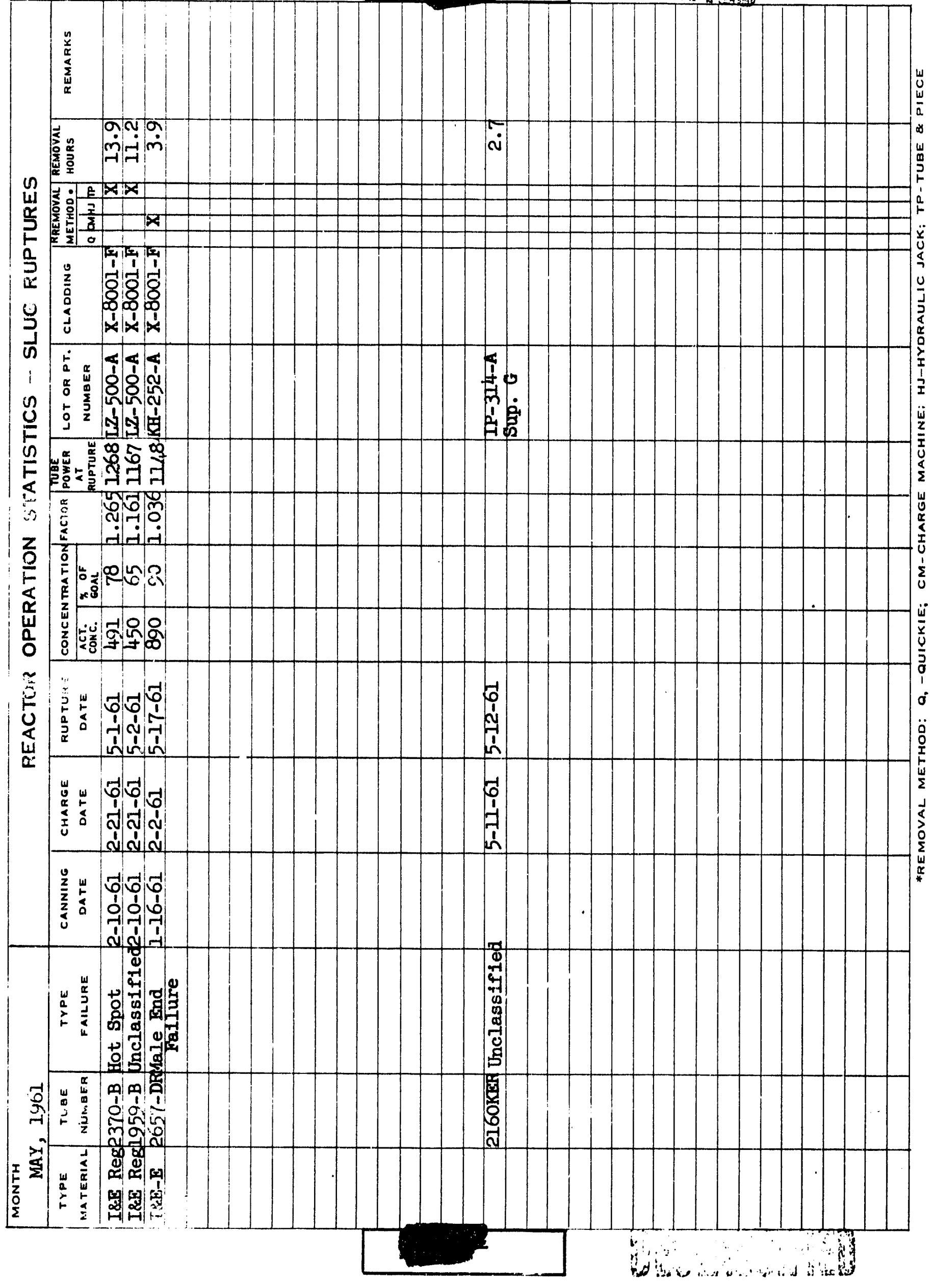




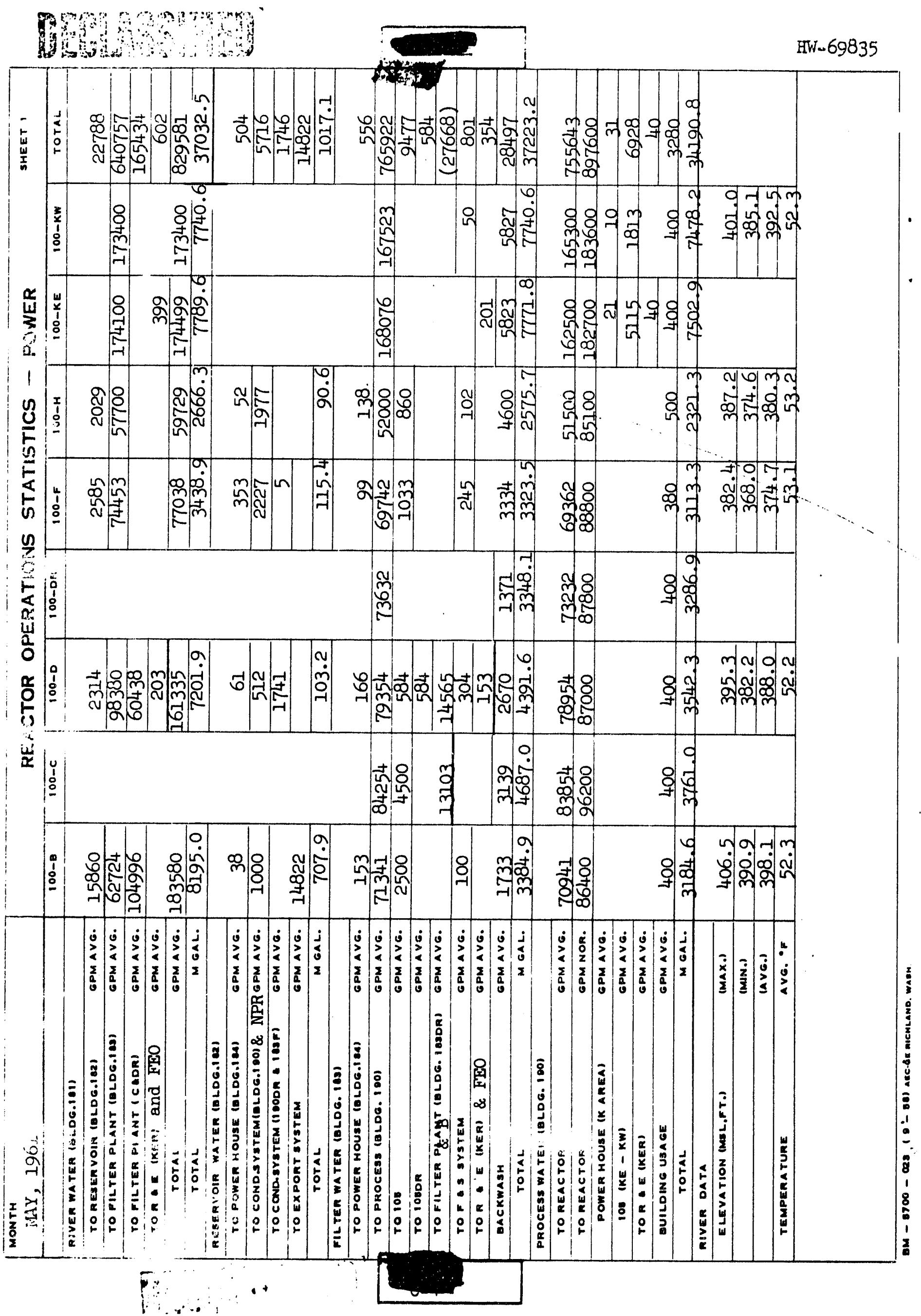




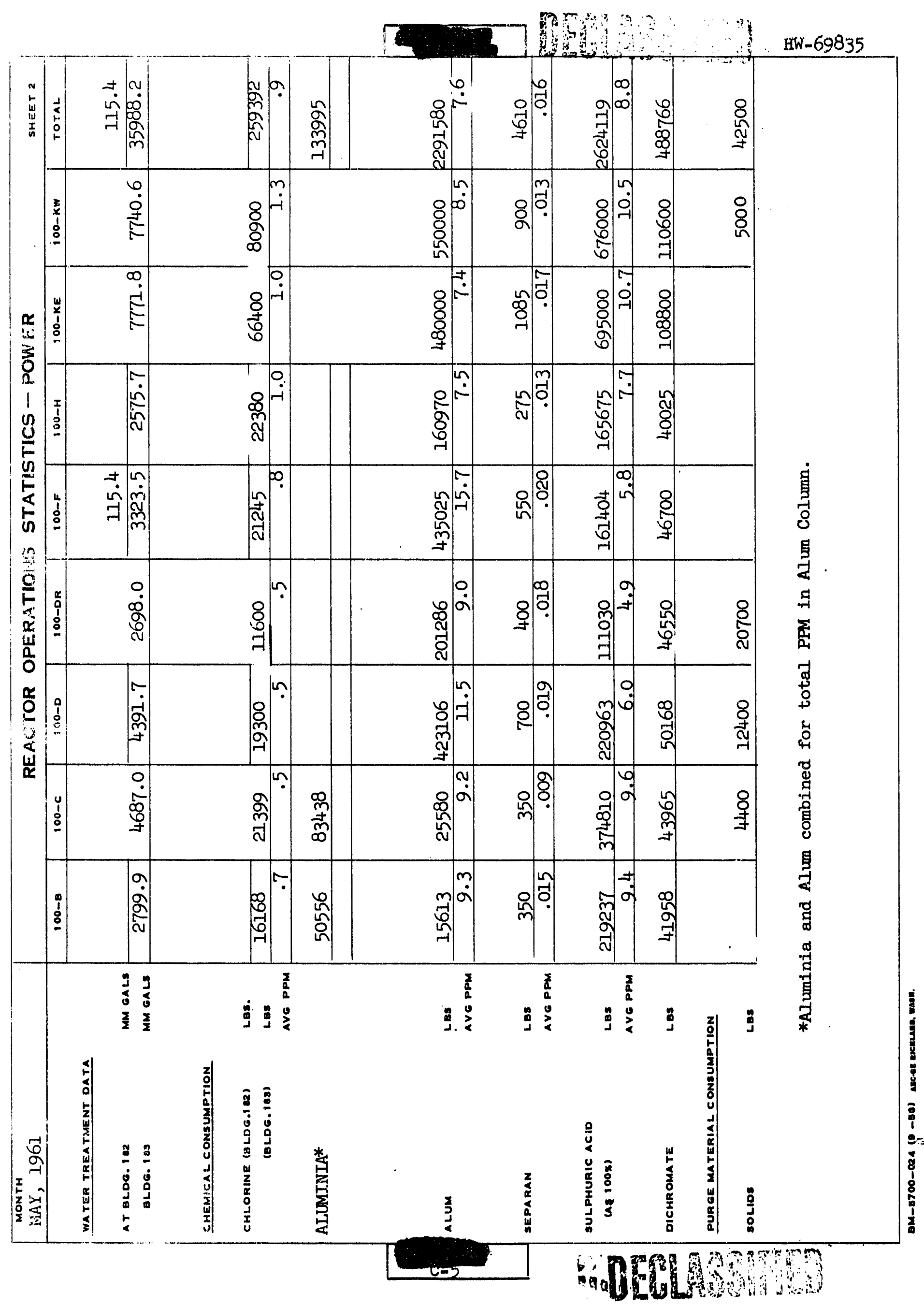




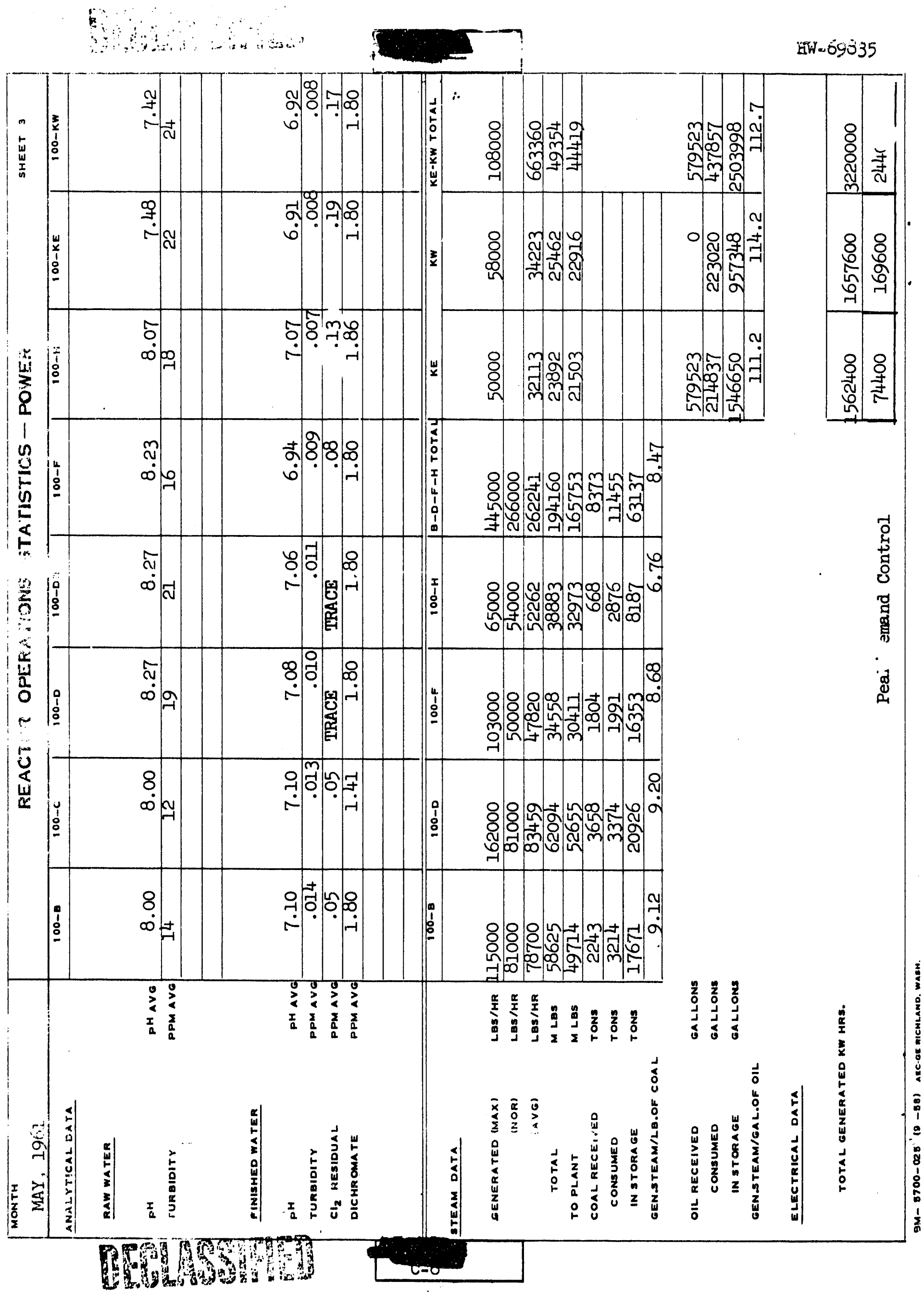


MAINIEINANCE PRACTICES OPERATION

Process Water Pump Impellers

The elght spare impellers ordered in March are scheduled for delivery in early July, 1961. One repalred impeller is at the vendor's shop awalting resolution of purchasing and contract negotiations between the General Electric Company and the vendor. There is currently one spare impeller for 190-DR and none for 190-B, D, F and $H$.

Rear Face Pigtail Connectors - Six Older Reactors

Tabulated below are the data on the inftial order of 3,200 pigtails as of May 26, 1961:

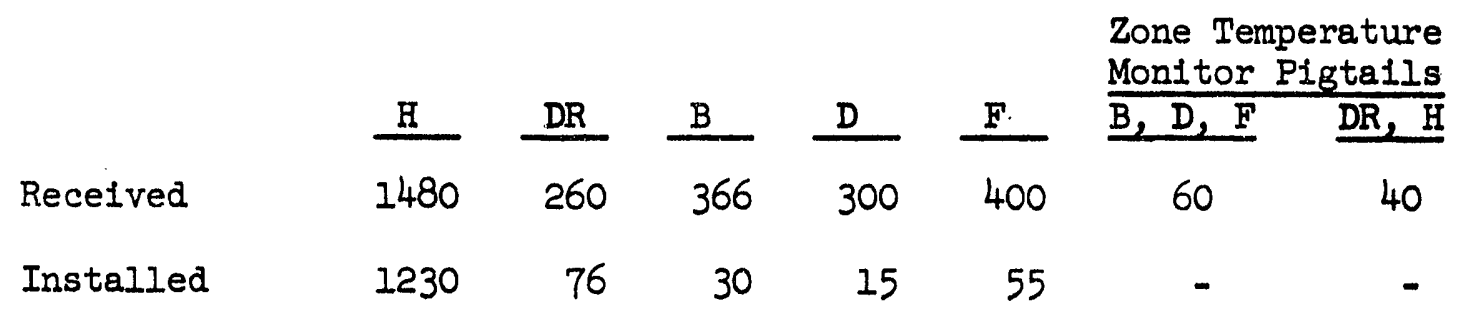

The second phase of the order for 6800 pigtails is being expedited; delivery is estimated for September.

Process Tube Van Stone Flange Tooling

The process tube trimmer design has been approved and tests were conducted with the powder-actuated Van Stone forming tool. An interim report, Document HW-69652, dated May 18, 1961, was issued.

\section{PLANT EQUIPMENT ENGINEGRING OPERATION}

\section{Gunbarrel Flange Retaining Rings - K Reactors}

Sample rings were removed from the $K$ Reactors for examination. Approximately 85 percent of the carbon-steel rings exhlbited stress corrosion cracks to a depth of 95 per cent of the metal. The front face samples exhibited approximately one crack per clrcumferential inch and the rear face samples about twice as many. The shear strength of the remaining metal thickness (approximately 93 per cent) is adequate at this time. Based on these findings, an inspection of each ring on the front face of $\mathrm{KW}$ and $\mathrm{KE}$ Reactors was performed by Maintenance personnel. Consultation is continuing on this problem, and direct assistance is beling provided in the further inspection of presently installed retaining rings.

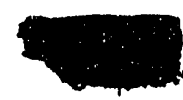




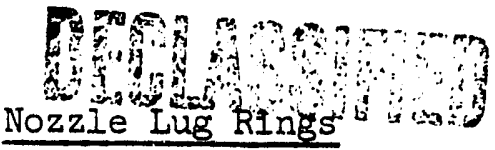

HW- 69835

Design Change No. 469 for a universal nozzle lug ring design was approved and 1500 lug rings costing $\$ 5.33$ each have been ordered. A direction arrow on top of each lug to ald in determining proper orientation during installation and to ald in checking orlentation during periodic inspections was included. Acceptance of the universal lug ring has made it possible to drop one line item from Spare Parts. The lug ring will fit either $1 / 8$ or $3 / 16$ inch keys. New flexibility has been provided because of f.ts abllity to fit the front or rear nozzles of any of the present reactors.

\section{Flux Monitor-Pressure Monitor Interlock System}

The deadline date of June 1, 1961, for having this system in operation as specifled in Process Standard C-060, will not be extended. An alternate proposal was made to the Plants after discussion with Process Technology, Research and Engineerling Section. Thls proposal covered a Bulk Outlet Temperature-Pressure Monltor Interlock that would automatically unbypass the Pressure Monftor System as soon as the bulk outlet water temperature reached a preset IImit. Design Changes are being prepared by the Plants oovering this approach.

\section{E-C REACTOR OPERATION}

\section{OPERATING EXPERIFNCE}

Limiting factors in the control of power levels were bulk outlet temperatures at B Reactor and the Operating Severity Index for rupture control s.: C Reactor.

Unscheduled interruptions of production at B Reactor were required for the removal of two ruptured fuel elements and the elimination of water leaks - both in-pile and external. At C Reactor water leakage from external hardware necessitated two unscheduled outages for repairs. A scram at C Reactor resulted from the uncontrolled entry of a vertical safety rod following fallure of an electrical relay.

\section{EQUIPMENT EXPERIIHNCE}

Thirty new process tubes were installed in B Reactor as replacements for thirteen with thin walls, ten ribless, five with leaks and two damaged during removal of ruptured fuel elements. Two rear face Parker fittings falled at $B$ and were repalred. Water leaks were repalred at two Van Stone flanges and at a nozzle connector elbow.

At C Reactor graphlte obstructions were removed from VSR channel No. 58 and the rod returned to serv1ce. HCR No. 7 was removed and burled due to a depleted polsoning effect; a new horlzonte? rod was installed. 


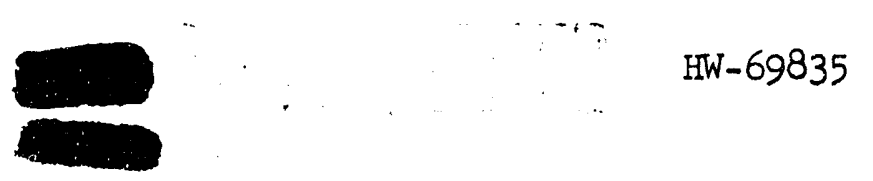

Water leakage from several rear face connectors at $C$ was stopped by replacing "O" rings at nozzle connector elbows and crossheadex adaptors. One process tube was replaced.

A BPA system power surge on May 3, originating in the Seattle area, caused a momentary loss of electrical power and the drop-off of four process water pumps then supplying outage requirements of B Reactor. All electrical components, relays and controls functioned properly at B Reactor and facilities; however, at $C$ Reactor a reverse current relay (controlling a motor-generator for auxiliary power to instruments) falled to function. Results included release of a VSR holding clutch, entry of the vertical rod and a conjunctional scram of the reactor; recovery was accomplished.

Power calculators at $B$ and $C$ Reactors were inspected by a representative of Foxboro Company. Several minor troubles were detiected including a faulty distribution transformer at B Reactor; replacement equipment was ordered and plant personnel were instructed by the vendor representative in proper techniques of equipment installation and testing.

A tenth process pump was started May 19, at Buflding 190-C, to supply C Reactor demands for cooling water.

\section{IMPROVEMENT EXXERIENCE}

At B Reactor eighty inconel pigtalls were installed to initiate the program for replacement of J-type connectors. Fourteen reamed venturis were installed in continuation of the program for increasing the bulk flow rate. Installation of the spline coller (Project CCI-906) was completed. and beneflcial use achleved at B Reactor.

Oonstant bleed lines were installed to reduce ie water temperature in emergency high tanks at both reactors.

Cooling water systems of both $B$ and $C$ Reactors were purged with diatomaceous earth; C Reactor was additionally purged with. Turco. Radiation dose rates in the $C$ Reactor discharge area were reduced by 56 per cent.

In connection with Project CG-889 - Modifications to the B-C Effluent System, interior work at the 107-C diversion box was completed.

Rewound stators were installed in the $4500 \mathrm{HP}$ synchronous motors of Nos. 1-A and 2-A process pump units at Bullding 190-BA.

The repair and recovering of outside steam line insulation is 85 per cent completed.

\section{RADIATION MONITORING EXPERIENCE}

Four cases of skin contamination (easily removed) occurred during rupture removal and tube replacement work. Personnel jose rates to $1 \mathrm{r} / \mathrm{hr}$. were experienced during rupture removal work, and to $3 \mathrm{r} / \mathrm{hr}$. during spline

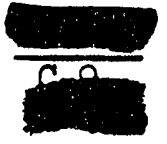


removal. Efforts to decontaminate personal clothing, contaminated to $5000 \mathrm{c} / \mathrm{m}$, were unsuccessful in one case. No personnel overexposure occurred.

\section{D-DR REACTOR OPERATION}

\section{OPERATING EXPERIENCE}

Power levels were limited at $D$ Reactor mainly by bulk outlet temperature and at DR by non-equilibrium following startups. D Reactor took a scheduled outage for charge-discharge, bumper nozzle installation and thermocouple replacement. One of the other two outages was a manual. shutdown when two front face caps were found not properly seated. DR Reactor's three outages were caused by a mupture and water leaks.

\section{EQUIPMENT EXPFERIENCE}

$D$ Reactor installed an additional 213 reamed nozzles for bumper fuel elements, bringing the total installed to 1635.

* program to replace all the rear face thermocouples at $D$ Reactor was begun with 506 installed during the scheduled outage.

Four vertical safety rod channels were broached at DR Reactor using a newly designed tool attached to a rod tip, beginning a preventive program to confront graphite movement that blocks the channels.

A bent guide rall in a DR transfer area loading pit was removed and rerlaced, using underwater divers from a marine construction firm.

\section{IMPROVEMEANT EXXPERIENCE}

Helium losses in the hlgh pressure system at 110-D were reduced by a lactor of 10 through a rearrangement of piping, elimination of 7 valves, welding of all pipe connections and substitution of the valve type. Revisions were made during shutdowns over a six month period. Monthly savings approximate $\$ 2,000$.

A traveling mlcrophone was installed on the DR discharge elevatur. This facilitates work which requires constant communication in the discharge area.

\section{RADIATION MONITORING EXPFHRIENCE}

Each reactor experienced two lapses of radiation control. At $D$ an instrument technician leaving the discharge area was found with a particle reading $1 \mathrm{rad} / \mathrm{hr}$. In his hair. The second was the finding of non-regulated coveralls contaminated to $360 \mathrm{mrads} / \mathrm{hr}$. At DR three Prwer operziors contaminated their personal shoes valking in the valve pit and riser turnels without protective clothing. The second lapse
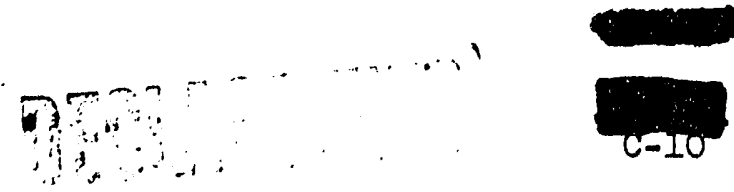
involved a craftsman who worked a short period in the discharge area without monitoring, then left without a clothing survey.

A maximum dose rate of $150 \mathrm{mr} / \mathrm{hr}$. was set for a diver doing underwater maintenance work in the DR transfer area loading pit. This dose rate was on the pit floor. Other readings ranged from 5 to $50 \mathrm{mr} / \mathrm{hr}$. The diver received an estimated total exposure of $163 \mathrm{mr}$.

\section{F REACTOR OPERATION}

\section{OPERATING EXPERIENCE}

Reactor power level during most of the month was based on tube powers determined by rupture control considerations. The power level was essentially limited by bulk outlet temperature towards the end of the month. Further changes in reactor loading resulted in an increase of reactor flow to $90.0 \mathrm{M}$ gpm.

All outages, including the one underway at the start of the month, were caused by rear connector failures or Panellit difficulties.

Water collection during the month reached a record low (for the past several years) of one gallon per day.

Two scram recoveries were attempted during the month but insufficient reactivity prevented restarting the reactor in both cases.

A BPA system power surge occurred at 9:07 a.m. on May 3, causing a 30 $z: i$ drop in the top of riser pressure.

\section{EQUIPMENT EXPERIENCE}

A collar was installed on the retention basin effluent line on the downstream side of the large anchor block to prevent line creep. This now provides a collar on each side of this block. The expansion joint immediately upstream from the anchor block was repositioned and the gaskets replaced.

A total of 122 tubes were probologged. Of these, ten had sufficiently corroded to warrant immediate replacement. Inspection of tube 3469-F confirms that $F$ Reactor tubes installed in 1959 are subject to the same type of accelerated internal corrosion as has been evident in other reactors.

Two air channels remaining from the overbore experiments were retubed and returned to service.

The Number 2 horizontal rod tip was replaced due to binding caused by verping.
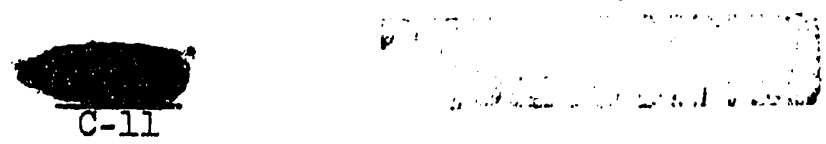
Inspection of the east raw water flume revealed severe erosion on about 10 feet of the ceiling of the flume. Recommendations will be made after similar inspections are made in other areas.

Significant items replaced on the reactor were: 4.5 process tubes, 64 process tube thermccouples, 135 rear face water connectors, 11 rear face gas seal boots, 11 venturls, 49 front nozzles for bumper fuel elements and 14 Panellit gauges. Approximately 1772 Panellit gauges were adjusted.

\section{IMPROVEMENT EXXERIENCE}

Installation of the Inconel rear face water connectors was started. of the 135 replaced, 105 were of the Inconel variety.

Work on cutting through the concrete backfill under the riser room continued. This work is associated with Project CGI-884 (Crossunder Iine).

The charging of 4" I\&E fuel elements in upper tube rows was started.

In an effort to increase water flow through the filter plant, the $2-W$ 2-E rewash lines were rerouted to the effluent flume. The preliminary effect of these changes has increased the flow approximately 1,500 gpm through the No. 2 filter. However, the long-range effects on the filter. will have to be determined.

The 183 sediment basin overflows were extended 10 inches and the water level in the basins raised accordingly. This caused the flow through the filters to increase approximately $500 \mathrm{gpm}$.

New control instrumentation designed to permit increased reliability during low steam loads has been completed on No. 2 and No. 3 bollers at the 184-F Building.

The metering orifice for the reactor gas flowmeter was replaced to increase meter accuracy and simplify calibration. (Revision DC \#386F-105-F Gas Flowmeter).

Tubes in the central zone of the reactor inside the enrichment ring have been converted to 32-plece charges.

\section{RADIATION EXPERIENCE}

Four employees were inadvertently exposed to alrborne reactor gas contamination when a shlelding bayonet was removed from a process tube channel while the reactor was still under a slight positive gas pressure. The occurrence did not cause an over-exposure and is reported in detail in HW-69619,

Revised process water treatment including high s.lum feed has had oeneficin effents on certain isotopic activities in reactor effluent water. No apparent effect has, as yet, been noted in rear face dose rates during
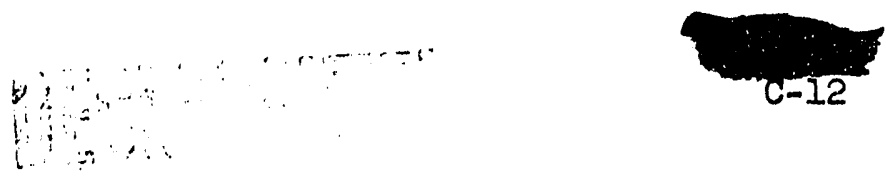

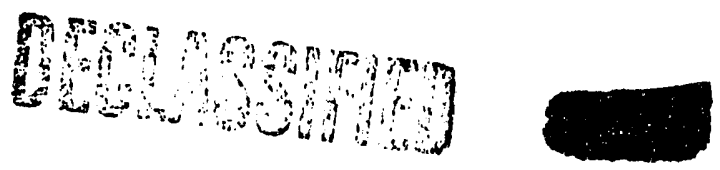

HW-69835

shutdown periods. A reactor purge with diatomaceous earth had insignif1cant effect on removal of contamination from process tubes. Similarly, increase of residual chlorine concentration by a factor of three in the far side process water feed, had no apparent effect on rear face radiation levels.

\section{H REACTOR OPERATION}

\section{OPERATING EXPERIENCE}

The highest level attained prior to the reactor outage on May 21 , for $\mathbf{E}-\mathrm{N}$ loading, was $1780 \mathrm{MW}$ and was limited by rupture control considerations. Following the E-N loading, a level of $1785 \mathrm{MW}$ was achieved. There were 330.4 outage hours during the month as a result of seven reactor outages. Six of these were unscheduled and one was scheduled. The six unscheduled outages resulted from rear face connector fallures, Van Stone leaks, an electrical power surge via the Bonneville Power, a Panellit scram, and a shutdown to correct high Panellit gauge readings on two newly charged process tubes.

\section{DRUUPMENT EXPFRIENCE}

No. 14 horizontal control rod, which had been binding at 225 inches out of the reactor, was inspected during the May 21 outage. The cause of the binding was corrosion buildup on the portion of the rod outside the normal operating zone. Removal of the corrosion corrected the malfunction. There was no evidence of rod damage.

Additional inspection of vertical safety rods, prompted by bearing fallure $\therefore$ the winch brake mechanism of No. 36 rod, (reported in April) revealed the same condition in rod units 41 and 53 . Rod 41 was repaired and rod 53 removed from service pending repair. Inspection of the remaining rod units will be made during future shutdowns.

Broached nozzles were installed on 142 additional process tubes during the month. Installation is now 87 per cent complete.

Inspections of pump running assemblies were made to 190-H annex pump units 5, 7, and 8. Extensive cracks on the first stage impeller and a broken intermediate sleeve on the No. 5 unit, and severe cracking of the No. 7 unit first stage impeller made replacements necessary. The No. 8 unit was in good condition.

Pesults of a forebay sand bar survey at the 181-H Building indicated that sand deposition has increased from 5,263 cublc yards in March, 1960, to 6,451 cubic years to date. No removal action is contemplated at present as there has been no change in depth of either the north or south channel entries to the pump inlet. Investigation is underway to determine a feasible method of permanently correcting the sand deposition problem.
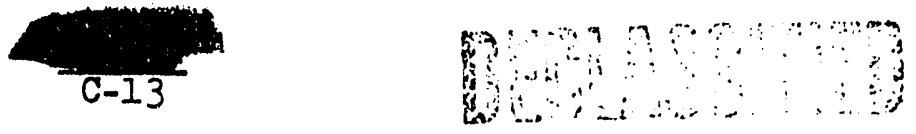


\section{TMPROVEMENT EXPERIENCE}

Charging of the E-N demonstration load, PT-IP-350-C, "E-N Demonstration Load for H Reactor," was completed. Phase one was completed during the unscheduled reactor outage of May 3, and consisted of charging a pilot central zone loading of 261 tubes. Phase two lnvolving 850 tubes was charged during the scheduled reactor outage of May 21 . Reactor loading at month end consisted of the following:

\section{Loading}

Central E-N Load

Fringe Blanket Load (Ball)

Enrichment - 43-piece charge (E)

Enrichment - 34-plece charge (E)

PCCF Charges ( $\mathrm{Ball}$ )

Total E-N Tubes

Miscellaneous Charges

Total Tubes
No. of Thube Charges

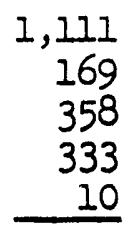

1,981

23

2,004

tileven hundred and twenty J-type connectors (pigtails), which were failing and permiting excessive amounts of water and steam in the discharge area, were replaced by Inconel spiral connectors for a total of 1,324 to date. Significant improvement in the amount of water and steam in the discharge area during subsequent reactor operation was observed. Additional replacements will be made during future outages unt1l the condition is corrected.

Fistension of the rear face top of the unit catwalk to the far side of the reactor was made to permit work on the top neoprene gas seal and thermocouple leads without consuming rear elevator time. As a result, extensive repairs to the gas seal were possible during the extended reactor outage of May 2l. The repairs reduced helium gas loss from an average of 16,300 cubic feet per day to 6,550 cublic feet per day -- a 60 per cent improvement.

The "Rear Face Crossunder Line" Installation (CGI-884) was completed during the month except for the automatic alr-operated valve which is not yet avallable. This installation will permit valving of all rear crossheaders to the process water effluent line prior to discharge by opening one valve.

Installation of the spline coiler (CGI-906) was completed and accepted for beneficlal use. Installation of the coller permits the necessary poison control for the E-N load. A total of 86 splines was used for the $\mathrm{E}-\mathrm{N}$ startup on May 28.

Installation of the first fan wheel has been completed in the No. 7 steam turbine-driven exhaust fan and the second is ine No. 8 electric

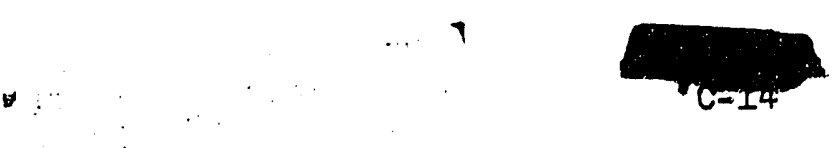


drive exhaust fan as part of Project CGI-79I, "Reactor Confinement." Installation of equipment in the 119-H Building is 85 per cent complete.

\section{RADIATION MONITORING}

The inside of the rear face process piping was decontaminated with Turco solution during the May 3 and May 21 reactor shutdowns. Dose rates in the discharge area were reduced from an average of $150 \mathrm{mr}$ per hour to $85 \mathrm{mr}$ per hour on the May 3 decontamination, and from $100 \mathrm{mr}$ per hour to $40 \mathrm{mr}$ per hour on May 21.

\section{KE-KW REACTOR OPERATION}

\section{OPERATING EXPERIENCE}

Power levels were limited at both reactors by the planned rupture control point for the major portion of the month. The seasonal rise of river temperature caused $\mathrm{KE}$ Reactor to be limited by bulk outlet temperatures during the last days of the month.

A Low voltage transient on the BPA system caused the separation of the emergency busbars B-E-C-F from the rest of the system at both $K E$ and $K W$ on May 3. The emergency generators assumed the load without incident and all relaying equipment functioned properly. Reactor operation was not affected.

\section{EQUIPMENT EXPERIENCE}

As a result of inspections made at both reactors of the front face tru-arc alap rings that position the gunbarrel flange, 18 defective or broken rings were replaced, although in no cases were the nozzle flanges found to be unsecured by the condition of the snap rings.

Thermocouple probes were installed in four regular metal tubes at KW Reactor for tube corrosion studies after water mixer dummies were positioned upstream from the eleventh metal plece from the rear. Probes were also installed into one tube of enriched metal.

Horizontal traverses of the V-l and V-2 test holes and of two process tubes indicated that no appreciable horizontal graphite movement has occurred during the past year.

\section{IMPROVEMENT EXPERIENCE}

A revision was made to the Number 2 dryer room by-pass valve at $\mathrm{KE}$ Reactor to enable improved control. of reactor gas flow as a means of reducing reactor gas usage.

The top deck of the "C" elevator at KW Reactor was waterproofed and a gutter and drain we.e installed to divert water away from personnel and equipment on
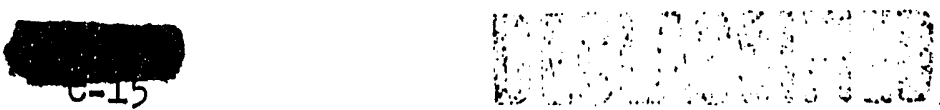
the lower deck. The change was made to permit front fuce maintenance work to be accomplished during reactor outages concurrently with charge-discharge operations.

\section{RADIATION MONITORING EXPERIEINCE}

Two employees recelved radiation exposures in excess of one rem per badge period during work in a 115 Bullding dryar room. A faulty isolation valve permitted flow of radioactive gas into the filter room piping where radiation levels would normally be very low under the existing conditions. The incident was investigated and reported in $\mathrm{HW}-69850$.

\section{SUPPLEMENTAL CREWS OPERATION}

The IPD P1le Operator-Ut1lity Operator rat1o (2.5:1) was increased to $3: 1$ as provided under the current GE-HAMTC Agreement.

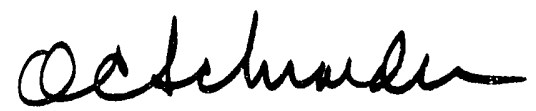

Manager, Manufacturing

UC Schroeder :tam 


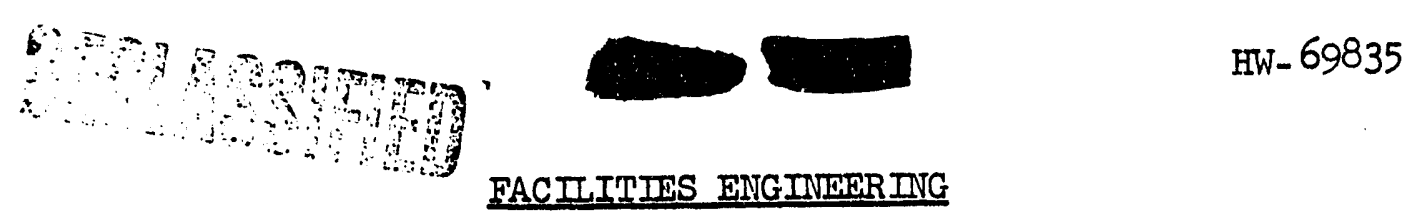

\section{REACTOR MODIFICATION DESIGN}

\section{RESEARCH AND DEVELOPMENT}

Arrangement and detall drawings for two alternate concepts of oversized process tube assemblies bave been completed and requisitions for this material have been placed. These alternate assemblies are planned for use on the next group of overbored process channels at 105-C Reactor. Work is currently underway on the design of tools for the installation and removal of the process tube assemblies. Prototype units of this equipment for use in preliminary testing are being fabricated in the 1717-H Central Maintenance Shop, due to insufficient time belng available to permit offsite procurement.

Analytical studies supporting the 105-C Reactor overbore program. continued. Preliminary results indicate that: 1) boring the tube channel 25 mils or greater above the process tube $0 . D$. has slight effect on graphite temperatures at larger specific heat generation rates, 2) composition of the reactor atmosphere should not exceed 50 percent helium if minimum graphite temperatures are to be maintained and 3) coring, to be effective, should range from 200 to $300 \mathrm{mils}$ and extend three to eight feet beyond the gunbarrel both front and rear.

Design tests have been prepared in support of the proposed 40 tube overbore program. These tests provide for testing the outlet gas seals, evaluation of the forged lug ring, evaluation of rear connectors and testing the rear nozzle water seal at the tube to nozzle joint.

Work concerning the rehabilitation of the vertical safety rods and the collection of graphite distortion data at $C$ Reactor continued. Efforts to clear graphite obstructions from the channels for vertical safety rods No. 41 and 58 were partially successful. Channel No. 58 was cleared sufficiently to permit the safety rod to be returned to service. Although channel No. 41 was cleared of complete blockage, protrusion of both graphite filler blocks and tube blocks into the channel remain a problem. Pieces of graphite in the bottom of the channels preclude the use of the Ball $3 \mathrm{X}$ safety system in either channel at this time. Additional data regarding the extent of the graphite distortion at 105-C Reactor will be collected during the next scheduled reactor outage.

\section{DESIGN PROJECTS}

\section{CGI-839 - Modification of Fuel Element Test Facility - 1706-KRR}

During an inspection of the primary heat exchangers at the vendor's plant it was noted that the outer coll was not supported but was permitted to rest against the bottom of the shell. Following the inspection the units were dismantled and spacer strips tack welded into the bottom of the shell. as supports.
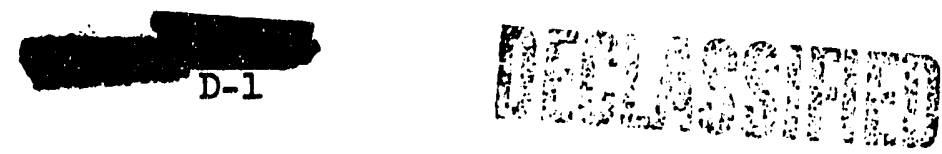

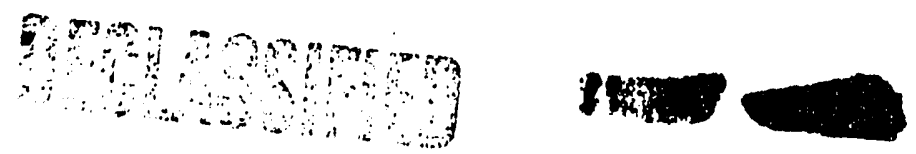

HW-69835

\section{CGI-844 - 100-K Coolant Backup System}

Design is 100 percent complete. Vendor proposals for the process pipe have been reviewed. Exceptions to the specifications were taken on all items by the four vendors submitting proposals. The specification has been modified to clarify the test procedures in question and new invitations to bid have been issued.

\section{CGI-883 - Increased Process Water Flow - 100 K K}

Detalled design which is 94 percent complete, has fallen 5 percent behind schedule. Final drawings for the $4160 \mathrm{~V}$ swltchgear have been recelved from the vendor, which will permit the completion of the remaining design draw1ngs. Propossls from four manufacturers for the submersible motor driven pumps for the 181-K RIver Pump Houses are belng evaluated.

Hydraulic model tests, conducted at Washington State University, for sizIng the orifice plate in the downcomer at the $K$ Reactors have been satisfactorily completed. The results of these tests indicate the downcomer approach sectIon may linit the maximum downcomer flow capability following replacement of the orifice plate. Additional fleld data is being obtained to evaluate the flow capacity.

Based on the results of the recently completed 183-K Filter Plant filter effluent capscity tests, recomendations have been made for minor modiIlcations to the filter plant. These changes are to decrease filter effluent flume flow restrictions in order to adequately handle the project flow rates and Install curbs around clearwell vents to control splashing. 


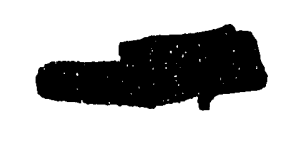

HW-69835

EQUIPMENT DEVELOPMENT

EXISTING REACTOR WORK

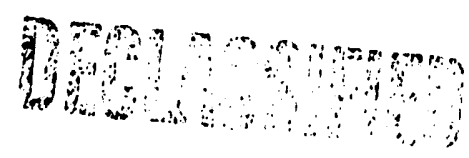

Reactor Modification Program

A front nozzle with captive venturl-pigtail and a flapper was removed from Thube 3874 of the 105-C Reactor for examination. It had been in service six and one-half months. The only deterioration noted was some galvanic attack of an aluminum seat near the brass flapper base. The examination completes the production test (PT-34l-AP) which authorized installation of this nozzle (designed for 0.200 inch overbore) for test of concepts only.

Instrumentation

Three vendors separately have been developing equipment to meet HAPO requirements for intermediate range nuclear monitoring equipment. Their devices are to take signal output from a gamma-compensated neutron chamber in the reactor and indicate power level (on a logarithmic scale) and reactor period. Briefly, the current status of this long-standing program is:

Sample instruments of two vendors have been checked in the laboratory and tried on DR Reactor. One of these, which was in most respects satisfactory, was returned to the vendor for correction of minor faults. The second was removed from the reactor this month to be prepared for testing in the controlled temperature-humidity chamber. It was found to have calibration and linearity errors that required circuit revisions; this is in progress. The third sample instrument has been given environimental testing and is awaiting receipt of new power supplies designed to give required stability in the face of Ine transients.

\section{Parker Fitting Replacement}

An occasional failure of welded outlet fittings on the rear cross header of $B, D, F$, and $D R$ Reactors has stimulated a program to develop replacement techniques and equipment. Several approaches are being investigated and complete development of the best candidate will be carried on. The objective is to provide equipment and methods with which maintenance personnel can quickly repair a fitting failure.

NEW PRODUCTION REACTOR WORK

Design Test Activity

The following assignments were completed and final reports issued:

*DT-1051 - NPR Process Tube Rupture Tests

*DT-1051 - Static Tube Deflection Tests

The following new tests were received by Equipment Laboratory and Testing:

* Originally issued as a single test.
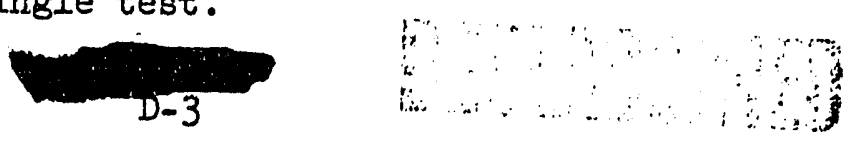


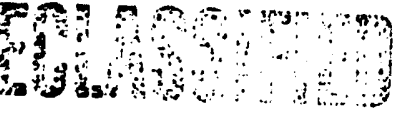

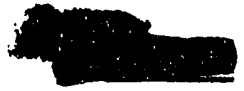

HW- 69835

DT-1110 - NPR Compact Relay for Fuel Handling Control Console

DT-1111 - NPR Flareless Tube Fitting Test

DT-1112 - NPR Production Horlzontal Rod Drive and Gunbarrel Assembly

DT-1113 - NPR Annunciator Functional Test

Deslgn Test 1081 - NPR Inlet Barrier Wall Sleeve Beal Plugs - was reopened to test the latest design. Design Test 1065, Pile Motion Transducer, was closed out.

Test activity and results were reported to the responsible designers on the following:

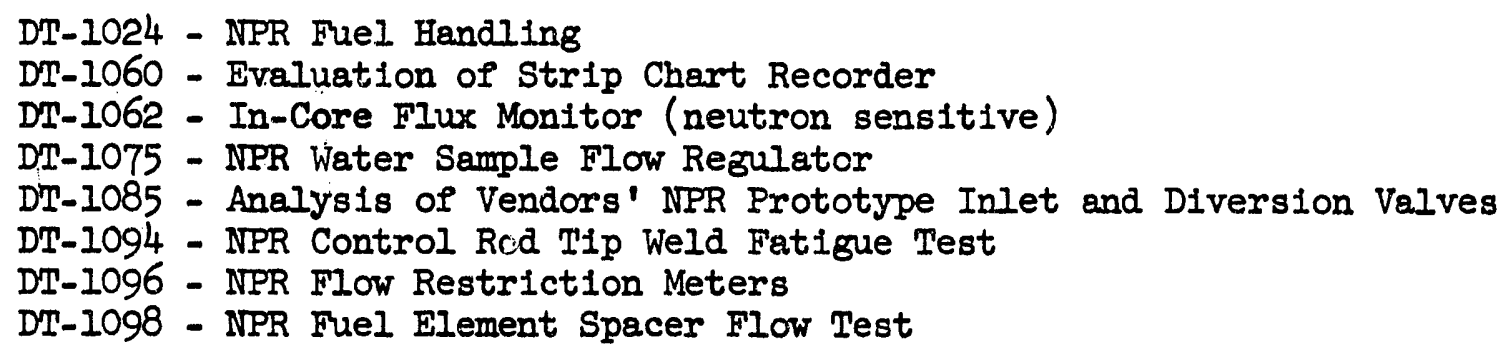

Nuclear Instrumentation

The high level (duo-deca for NPR, octant for existing reactors) nuclear monitoring system prototype is complete in the laboratory. Critical dualinput indicating meters received last month were found to exceed required tracking accuracy. A production test is being circulated for on-reactor testing of the system

NPR-PCE LOOP

A new impeller was installed in the NPR-PCE Loop canned rotor pump to replace one which had cracked. 


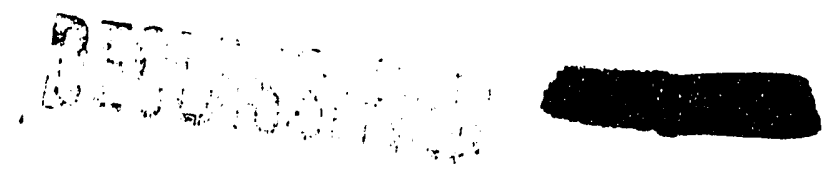

HW-69835

PLANT ENGINEERING

DRAFTING

Services provided during the month:

New and revised drawings 228

Layouts and sketches 92

Microfilm prints reproduced $\quad 550$

Microfilm drawings added or retired 2006

Ozalid check prints reproduced 970

Customers services - Microfilm files 289

Customers serviced-Catalog files 45

Catalogs added to files 91

$B P F^{\prime} s$, specifications, et cetera 20

EQUIPMENT APPLICATION ENGINEERING

Bumper Fuel Charging Machine and Material Handling System

A prototype magazine charging machine for bumper fuel elements was demonstrated May 18, in the 189-D Laboratory for engineering review purposes. A charging time of 40 seconds per tube, arbitrarily established for this demonstration, was achieved. Current efforts are directed toward fabrithe charging machine.

REACTOR, PLANT ENGINEERTING

High Speed Scanning Temperature Monitor for a K Reactor

Preliminary functional requirements and justification for the proposed high speed scanning temperature monitor system for 105-K Reactors have been established. Currently, accessory equipment is being evaluated for possible inclusion in the basic system. Three drawings and a preliminary specification have been transmitted to the vendor for his review.

Rear Face Plping Studies - B, D, DR, F, and H Reactors

Two propotype flexible joint installations are being evaluated as potential solutions to reactor rear header vibration and thermally induced stress problems. An installation made on header $\$ 25$ at 105-H Reactor about satisfactorily. A second instected for the fourth time and is functioning

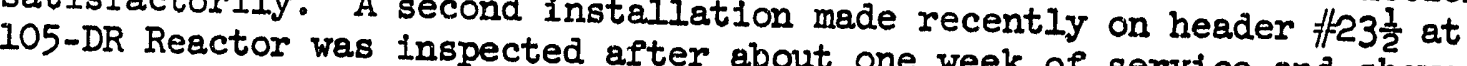
evidence of leaking.

These installations are to be disassembled perlodically for gasket inspection. The graphite asbestos gasket at the H installation looked satisfactory
at the first inspection.

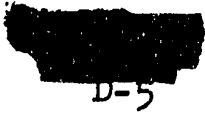




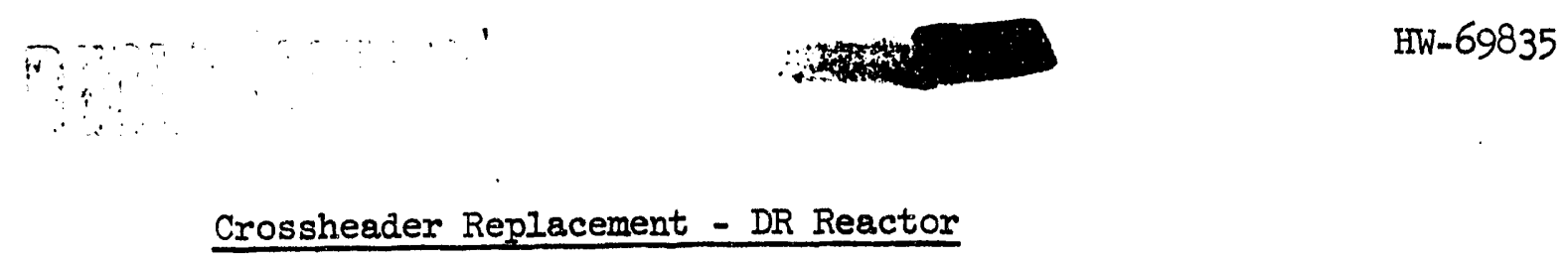

The removal of a complete crossheader from 105-DR Reactor for metallurgical and mechanical examination has been authorized under Production Test Authorization IP-352-AE. Design criteria have been established for the replacement assembly which provides for using enlarged fittings and connectors but which also provides for easily returning to existing size hardware. This flexibility allows on-plle demonstration of benefits to be gained from various design improvements.

WATER PLANT \& UTILITIES ENGINEHERING

Optimization of Power House Function in Support of Reactor Safety

To reduce costs, the feasibllity of operating the 184 Powerhous es at lower steam loads has been under study. One phase indicated the need for modifled control instmumentation. This equipment was installed at 184-F and numerous tests conducted. Improved boiler pickup characteristics have resulted.

\section{Unattended Reliablity of Boller Operation}

Conceptual engineering has been completed and project proposal preparation initiated to provide for the installation of one oll-fired boiler at the 184-H Powerhouse. The concept involves improvements in the unattended reliability of boller operation and operating economy. In summary the equipment includes four oil burner assemblies, automatic lgnition and supervisory safety controls, a new forced draft fan, required duct work, a fuel oil supply pump, associated electric wiring, piping equipment and valves and instrumentation for initiation, control, and integration with the existing station combustion control system. Fuel oll storage is to consist of two rented 10,000 gallon heated tank cars.

BPA Electrical Disturbance

A preliminary engineering review was made of the effect of the electrical disturbance of May 3, 1961, on IPD equipment and operation. Indications are that the effects were significally less than what could have been expected. In general, equipment operation was as intended by process standards. The transient as measured at HAPO does not reflect the seriousness of the large power swings on other parts of the BPA system which had the final result of dropping more than 20 percent of the Northwest (West Area) generation capability from the system. A separate report is being prepared.

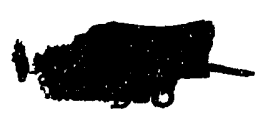




\section{PROJECT ENGINEEERING}

\section{PROJECTS}

CGI-791 - Reactor Confinement

Phases II-B - Filter Buildings

The Commission has forwarded the specifications for stabilizing the 117-Building berms to the J.A. Jones Company. They will let; a Iump Sum Contract

for the work.

Phase III - Ventilation Modifications and Tie-ins

100-B and C - The I19-B and C Sample Buildings are complete except for munning the Acceptance Tests.

100-D - The Acceptance Test on the ventilation supply fans in the 105-D Building was completed.

100-F - The Acceptance Test on the ventilation supply units in the 105-F Building was completed.

100-kE - The first set of filters for removal of halogens from the reactor exhaust gases was put into operation on May 26.

100-KT - The Acceptance Tẹsts hove been completed on the diesel driven fans.

General - The straddle trailer fabricated by the Edwards Equipment Company of Yakima, Washington, was inspected and accepted on May 19, 1961.

CGI-839 - Modifications to Fuel Element Test Facilities, 1706-KER

Construction of the No. 4 Recirculating Loop revistons started May 29. CGI-844 - 100-K Area Coolant Backup

Request for bids for construction of the underground pipe and the pump house were sent out by the J. A. Jones Company on May 13 with the bid opening set ior June 2 .

\section{CGI-883 - Increased Process Water Flow - 100-K}

An order wes placed by the Commission with Byron Jelckson Pump Company on May 25, 1961, for ten process pumping sets - primary pumps and secondary impellers.

CGI-904 - Improvements to Gamma Monitor Systems 105-B, C, D, DR, F, and H Installation of new sample room components at 105-

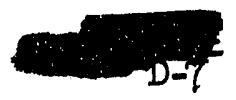


MJA-21, 25, 29 - Pressure Monitor System Improvements, 105-C, H, KE, and KW

Prototypes of the revised Panellit gauges to be installed were tested and approved. Vendor expects delivery of gauges to start July 1 .

CPFF CONSTRUCTION SERVICE CONTRACTOR - LIAISON

Issued seven new work orders and supplemented one old job for a total of $\$ 13,693$ to J. A. Jones Company in the month of May.

PLANT FORCES WORK REVIEW

The Labor Standards Board approved four jobs for assignment to Plant Forces, which are estimated to cost $\$ 52,052$.

PROJECT PROPOSALS

Project Proposals Subinitted to AEC

CGI-931 Production Reactor Mock-up Facility

CGI-933 Water Treatment Pilot Plant, 100-K Area

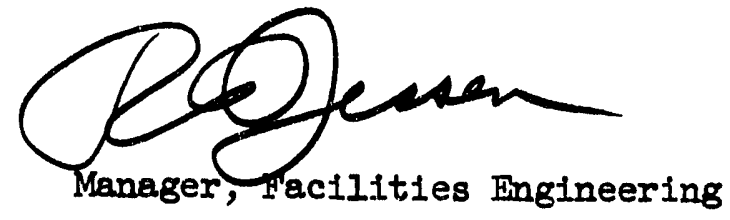

RT Jessen: dgm

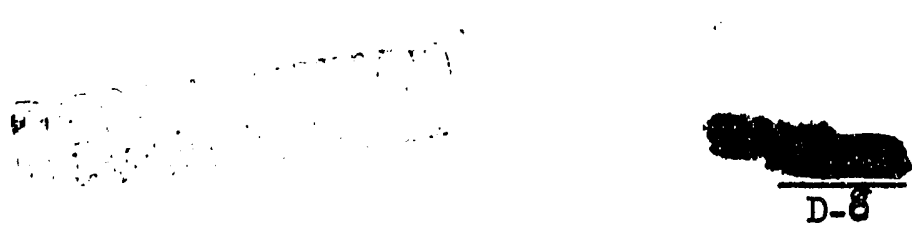




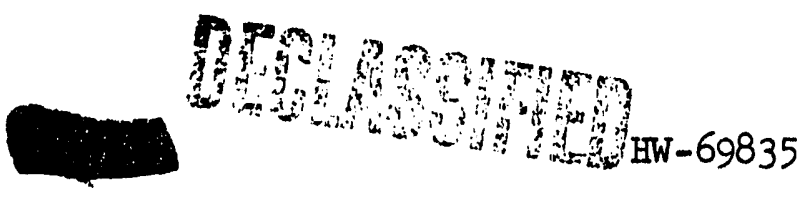

NPR PROJECT

PROCESS DESIGN OPERATION

Research and Development

Preliminary studies have been Initiated to investigate the general parameters of future advanced production reactors. A broad review and updating of past studies involving recirculating reactors with and without power recovery is planned. Such an investigation will provide cost comparisons to future reactor modifications and will be consistent with the general policy of remaining alert to all possible methods of potentially reducing plutonium costs.

Prototyplcal samples have been recelved of a $z$ lrconfum to carbon steel coextruded jolnt.. These samples are of the NPR process tube size and. tests are being formulated to evaluate potential use as replacement tubes in NPR or other high temperature reactors. Conslderable cost savings could be realized if such a joint proves acceptable from a corrosion and thermal shock standpoint.

A meeting was held with the AEC and BPA on May 12, 1961 to discuss the results of analysis and studies made by BPA in regard to the reliability and Independence of a second NFR power supply from the Wanapum substation. As a result of the meeting, BPA is making further fault studies to predict voltage and Irequency transients at the NFR plant.

A document, HW-69361, was issued reporting the results of a study of modiflcations that will be required for the reactor and 105 Bullding if the INPR is converted to dual purpose operation. Conversion changes to the reactor are not major and all changes can be made during the extended outage required for heat dissipation modifications.

Project AEC-179

Comments were sent to the Commission on the Burns and Roe draft of a control concept for the dual purpose plant and on the turblne-generator specifleations. These two 1tems are interrelated since the turbinegenerators will use the major portion of the reactor plant secondary steam.

A document, $\mathrm{HW}-57043$, BEVI ADDI RD2, was losued revising the reactor design bases for Phase III. The primary result is an increase in expected secondary steam pressure of about 120 ps 1 for the same reactor thermal level. Providing turbine-generators capable of using the higher pressure efficlency would result in a slgnificant reduction in fuel cost during Phase III operation. Flextbility for utilizing higher steam pressures apparently had not been serlously consldered in previous contacts with turbine manufacturers. Further discussions will be held to determine its implffations in the preparation of specifications.

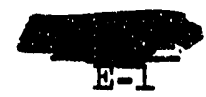




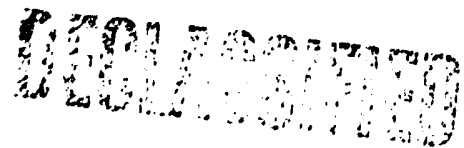

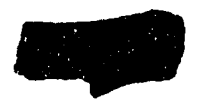

EW-69835

Project CAI 816

General Electric Company has submitted comments on the flrst six sections of the 109-N 1nstrumentation and control speciflcation which Burns and Roe, Inc. submitted for scope purposes. Extensive functional information has been developed and transmitted to Burns and Roe, Inc., which when added to the inftial six sections would more closely meet the General Electric defintition of scope. General Electric personnel will discuss these proposed additions with Burns and Roe, Inc. at Hempstead in early June.

Difficulties in detecting and malntalning the 11quid lovel into 109-N primary heat exchangers are under study by the Balley Meter Company. The Bailey Meter Company has made prellminary plans through Ka1ser Engineers to conduct tests at the Combustion Engineering Company's test facilities in Chattanooga, Tennessee.

The infitial fabrication phase for the charging machlne has been essentialily completed. The bast a motions involved in the tubular charging magazines have been demonstrated. The controls and electrical circults wili be Installed in the paxt phase in the development of this plece of equipment.

Prototypes of the process channel inlet and diversion valves have been tested at Hanford. A number of prototypical valves have qualifled for front face inlet valve use; however, to date, only one prototype appears acceptable to be applied at the rear face for diversion. In addition to the high dependability required of such a diversion valve, the transition of flow from the normal route to the rear beaders to the diversion beader must be accomplished in a manner so as not to cause flow Iluctuat1ons which would result in a reactor scram.

\section{DEVELOPMENT AND TESTING}

It is est1mated that IPR development and testing 1885 percent complete as compared to a schedule of 86 percent.

Flow tests have been completed on prototype inlet and diversion valves Irom Crane, Atwood and Morrill, Chandler-Evans, and Mason-Me1lan. Atwood and Morrill is in the Iinal stages of completing enviromental testing required by the prototype program. The three other vendors have comleted testing and have submitted final test reports and production proposals for General Blectric evaluation. The review of available information is near completion.

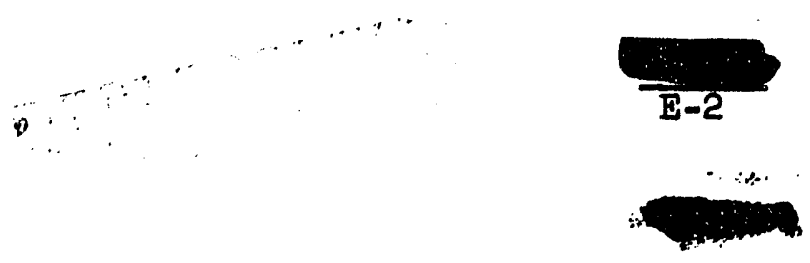




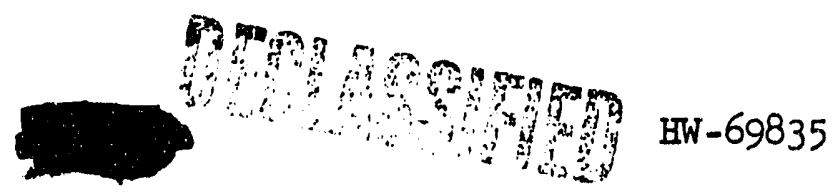

DEVELOPMENT AND TESTING (Continued)

Activity with the Component Test Loop continued on repair and modification. A new impeller was installed in the canned rotor pump to replace the unit in which a flaw was detected during recent inspection. The new 200-HP pump and connecting lines were. cleaned in preparation for performance of acceptance tests. This larger pump will be used in conjunction with the full-scale mockap of a process tube asserably. Materials for this assembly have been ordered, some have been recelved, and completion is expected by June 15. The first test scheduled for the mockup is an evaluation of dumy fuel spacer vibration.

NPR fuel elements were dropped onto an underwater chain-link mat to evaluate this device as a mechanism for minimizing fuel element damage. In one test series, seven fuel elements were dropped vertically and minor displacement was noted between the inner and outer tubes, a phenomenon observed in earlier tests. Three fuel elements with an alternate fixing member and clip design were also tested. On the first drop of each, no disengagement was noted. In subsequent drops of these same fuel elements, partial separation of a minor degree was observed. Additional tests have been scheduled of alternate mat concepts, fuel element flxing devices and slug trajectory control equipment.

Final reports were 1ssued on NPR Process Thube Rupture Tests and Process Tube Deflection Tests.

Prototype flow monltor components have been tested at the Instrument Development Laboratory and others are expected. Prototype pressure to electrical transducers have been recelved from Barton and swartwout. Problems associated with these flow transducers have been communicated to the vendors. Testing was inftiated of two solid state electronic flow monitors from Avlen and Hydro-Alre. The prototype monitor from Stromberg-Carlson has not been recelved.

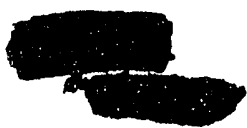



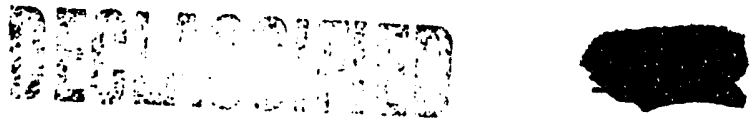

HW- 69835

\section{FIELD AND OPERATIONS ENGINEERING OPERATION}

Construation

105-N and 109-N Bulldings

During the period April 26 through May 26, 1961, Kaiser Eingineers placed aproximately 1,330 cubic yards of concrete in the $105-\mathrm{N}$ Building. This represents an average placement rate of 58 cubic yards per day and brings the total concrete placed to date by Kal ser in the 105 Building to approxdmately 13,330. About $90 \%$ of the Qdecking has been installed at the $(+) 58$; level and about $20 \%$ of the concrete has been placed on top of the Q-deck for the $(+) 601$ slab.

The application of the elastrometric coating in theilinlet and otitilet pipe spaces from elevation (-)12' to elevation (-)21'4" is in progress. Work is underway in these same areas on the steel plate liner.

Foothill Electric, the CPFF electrical contractor, started the installation of exposed conduits in the 105-N Building on May 3, 1961. Lord Electric, under subcontract SC-99, started work on the exposed conduit outside of area 2 on the 105 Building on May 18, 1961.

Approximately 95\% of the embedded electrical materlal has now been installed by Power City, Inc. under subcontract SC-61 in the 105 superstructure.

Progress on bid package SC-87 for the permenent lighting installation in the 105 Building is being delayed by poor delivery of lighting fixtures, interlocked armoured cable, heat and radiation resistant wire, and installation of ventilation equipment.

The Bay Company and Harder Industrial have continued their work throughout this month on the general building piping systems including steam condensate, filter water, shield cooling water, drainage, and gas piping.

HUICO moved three $40^{\prime}$ sections of the $24^{\prime \prime}$ emergency raw water In into Corridor \#1. These were opened and inspected for cleanliness and found to be unacceptable on this point. The piping has been removed and returned to HUICO's shop for cleaning.

Work has been started by Kaiser Engineers instrument people, the activity being primarily on the gas system instrumentation. The gas instrument relas valve and transmitter racks have now been installed in the gas instrument room and some of the tubing runs for these racks completed. Plywood mock-up valve racks have been placed in the left side flow monitor room in preparation for the installation of wall penetration sleeves and tubing to these racks.

Drake Cleveland, the subcontractor on the 109-N Buflding has proceeded with the pouring of concrete gmangell walls and has started 


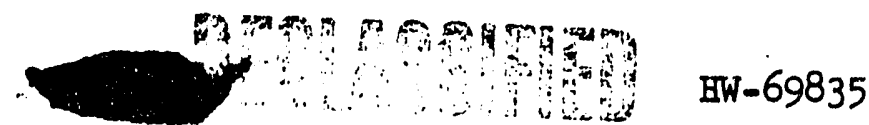

preparation for forming and pouring the cell roof. Two of the primary loop heat exchangers have now been installed in cell 3 of the 109-N Building.

153-N Building

Work has continued on the installation of switchgear and cable trays. 163-N and 183-N Buildings

Three of the four pumps in the chemlcal pump station bullding are in place and the piping is being installed. The filter beds are in place and work has continued on the coagulator basin installation.

181-N Building

Work has been started on the installation of the electrical switchgear. I82-N Building

The excavation for this bullding has been completed and forming has been started for the footings. The top has now been placed on the deminerallzed water storage tank and two of the other water storage tanks have the side walls nearly completed.

184-N Building

The work on the refractory on the boller has continued and the stack has been set. The structural work on this building 18 nearly complete and approximately 30\% of the metal siding has been applied.

$230 \mathrm{KV}$ Transmission Line

FInal inspection is scheduled for June 2, 1961.

P1le Erection

All base "I" sections have been shipped from Baldwin-Iime-Hamilton, whth two carloads received on plant. The prototype boron plate is still in machining, but procedures and welding have been approved.

Crate fabrication at Yuba Consolidated Industries is proceeding satisfactorily again after a drop-off in effort. Elght (8) crates have been recelved on plant, and check-out here indicates them to be within tolerance.

Establishment of the afrlock still awatts completion of roof assemblies and first foundation unit, but indications are these will be complete as required.

Temporary Construction

The General Electric TC facilt.me in place and were occupied Moy 29, 1961. Miscellaneous completsan. cal and plumbing work is nearing 

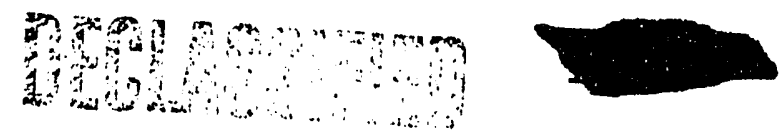

$\mathrm{HW}-69835$

Graphite

Overall production of complated detalis is now (as of May 27) 65\% complete compared to the scheduled $78 \%$.

The two additional traveling head vertical mills were recelved from Stetson-Ross on May 15, and were first utilized for production on May 25. The production rate from these machines is now $108 \mathrm{bars} / \mathrm{shift} / \mathrm{line}$ with a net reject rate of $5.0 \%$.

Graveyard shift was dropped effective May 15, and alI personnel were transferred to either day or swing shift in order to obtain more utilization of the supporting lines.

Mock-up of completed details was initiated on May 17, and now stands at 1.0\% complete compared to the scheduled 12\%. At present, the day shift is operating with about half the optimum number of craftsmen due to delay in receiving additional clearances. Pending receipt of the necessary clearances, it is intended to fully man the day crew and ultimately. extend the mock-up operation to a two-shift operation.

Following a re-evaluation of potential graphite contraction problems, it has been decided to overbore the process tube entry bars in the top ten tube rows of the reactor. Estimates for performing this additional operation has been requested from Kaiser Engineers and National Carbon Company. Design is also considering some overboring of approximately 200 additional entry bars but cannot verify this until they have had sufflcient time to re-run their computer program which will require about three weeks.

The last eleven bars on the Speer Carbon Company order were shipped on May 25. Shipments from National Carbon Company are proceeding at the scheduled rate and well ahead of machining requirements. Overall procurement is now $98 \%$ complete.

\section{Zirconium}

A total of 514 tubes have been processed through the autoclave operation; 434 of these tubes have been accepted as complete, approximately 80 tubes require rework by grit blasting and re-autoclaving.

All test and processing equipment functioned satisfactorily through the month. Completed tube output is $4.8 \%$ ahead of schedule.

833 NPR process tubes and 685 graphite cooling tubes have been received to date. Status of individual tube orders is as follows:

Chase Brass - 55 tubes were received on May 16, 1961, which brings the total to 76 and completes this order.

Allegkeny-Iudlum - Order is complete at 79 tubes. 


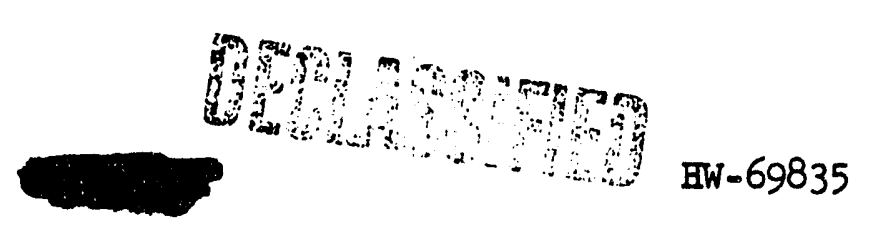

Harvey Aluminum - Pilot order is complete at 71 tubes. 607 tubes have been receIved on the production order.

Wolverine Tube - Delivery of the grahite coolir.g tubes is complete at 685 tubes. Ten of the 13 required flux monitoring cooling tubes have also been completed.

Primary Loop

The following was the status of aproval data on the HUICO subcontract as of May 31, 196I:

Total Number Received

Number Approved

Number Approved with Exceptions

Number not Approved

Number Currently being Reviewed

Number received for Information

Only No Approval Required

Number of Resubmittals Received

Number of Resubmittals Returned
1153 (include 387 recelved for information only)

387

62

224

33 (Include 27 resubmittals)

387

1073 (include 260 information

756 only resubmittals)

Fabrication work is proceeding very slowly in the HUIC shop. Only seven spool pieces have been delivered to the fleld and all seven are presently on rejection status. Three pieces are not in acceptable cleaniness state, three have not passed radiography requirements, and one is dimensionally incorrect.

Administration

The following material was processed by Drawing and Speciflcation Control diring the period of April 21, 1961, through May 20, 1961 :

$\begin{array}{lr}\text { Drawings } & 474 \\ \text { Criterla } & 21 \\ \text { Specifications } & 32 \\ \text { Requisitions } & 94 \\ \text { ATP's } & 2 \\ \text { Other } & 47 \\ \quad \text { Total } & \text { 664 }\end{array}$

Reviews were completed and formal comments were offered on engineering material as follows:

Drawings 106

Speciflcations

Scope

ATP' 8

Total

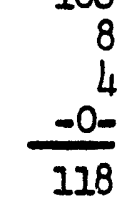


$\mathrm{HW}-69835$

PROGRAM EVALUATION

Design Status

$\begin{array}{ll}\text { Wt'd Certified } & \begin{array}{l}\text { Actual } \\ \text { Total }\end{array} \text { 年hedule }\end{array}$

Reactor Plant as of 6/1/61

Title I

Scope

100

100 (1)

Title II

$\begin{array}{lrrl}\text { Drawings } & 70 & 89.0 & 86.5(2) \\ \text { Specifications } & 8 & 100.0 & 94.2 \\ \text { Requisitions } & 8 & 75.0 & 74.6 \\ \text { AIIP's } & 4 & 43.0 & 22.9 \\ \text { Development and Testing } & 10 & 82.0 & 85.3 \\ \quad & & & \\ \quad \text { Total } & 100 & 84.0 & 84.0\end{array}$

Heat Dissipation Plant as of 6/1/61

Title I

Scope

100

98.75

Title II

Deta11 Des1gn

$87.0 \quad 90.0$

No. Issued to 5/27/61

Req'd Scheduled Actual

Scope Drawings

Preliminary Drawings (b1d)

Detail Drawings (for const.)

Specifications (bid)

Requisitions

AIP's

51

930

980

155

173

-

Composite Design Completion as of $6 / 1 / 61$ (Reactor and Heat Dissipation Combined)

Total

$\begin{array}{rr}51 & 50 \\ 885 & 885 \\ 870 & 870 \\ 145 & 145 \\ 162 & 162 \\ 0 & 0\end{array}$

Certifled Actual

Schedule of Complete

$87.2 \quad 88.4$

(1) This percentage represents only the completion of 44 criteria and does not include updating or revising.

(2) The number of required drawings is changed from 2300 to 2400.

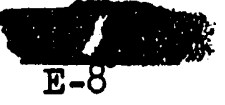




\section{Cost Estimate}

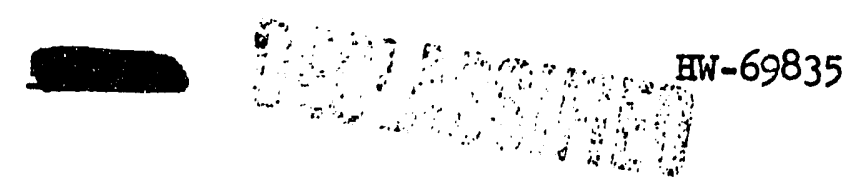

No cost estimate revlew meetings were held during this reporting period. The next review meeting is scheduled for June $14,1961$.

\section{Schedules}

No revisions to the over all project schedule were 1ssued during this reporting period. A revised construction schedule, currently under formation by Kalser Inglneers, will be presented to the AFC on about June 14, 1961.

The construction status as of $6 / 1 / 61$ is as follows:

Schedule of $2 / 13 / 61$ Actusl

Temporary Construction

General Area Systems

105-N Bullding

109-N Heat Bxchanger Building

163N-183N Water Treatment

181-N River Water Pump House

182-N H1gh Ilft Pump House

184-N Standby Power House

ITPR Project (CAI-816)

\begin{tabular}{rr}
59.0 & 59.0 \\
21.0 & 14.0 \\
14.0 & 15.0 \\
14.0 & 11.0 \\
28.0 & 45.0 \\
67.0 & 93.0 \\
3.0 & 2.0 \\
19.0 & 26.0 \\
\hline 17.0 & 17.7
\end{tabular}

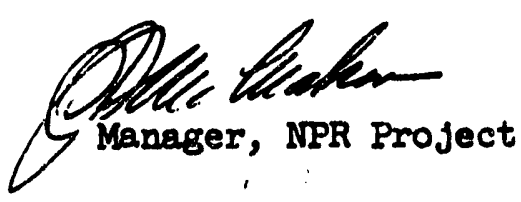

JS McMahon:me 


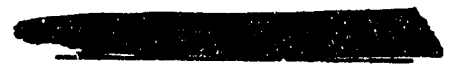

\section{FINANCIAI}

\section{GENERAL ACCOUNTING SECTION}

During May, six employees attended Professional and Trade Society Meetings for a total cost of $\$ 1$ 017.11.

One employee atterded a seminar on "Using Iinear Programing for Better Production and Inventory Control". Total cost was $\$ 206.01$.

Contract and Accounting was advised of the closing of FY 1961 and Prior Years Budget Items 57-a-2 and 58-b-4 in a letter May 13, 1961.

\section{PRODUCTION COST \& BUDGET SECTION}

A document comparing the cost of aluminum sulphate with raw bauxite for reducing $\mathrm{P} 32$ in reactor effluent was issued.

The annual physical inventory of coal piles by survey is scheduled for the period May 23-26, 1961. The inventory procedures to be used by fleld personnel were distributed.

\section{PERSONNEL ACCOUNTING}

Total number of personnel assigned to the Department at May 31, 1961 was 2 286, an increase of eleven over last month.

There was $\$ 798$ paid to Department employees for suggestion awards during May, 1961. Calendar.year to date $\$ 1766$ in awards were paid.

\section{PROCEDURES}

During the month of May, the conversion of the essential material bookkeeping program to electronic data processing was initiated in all areas. It is expected that parallel runs will continue through July when the formal machine program will be written.

The power forms for $K$ Areas have been revised and the new reporting procedures should begin in June.

\section{AUDITING}

Revisions to 35 AEC Manual Chapters were reviewed for their epfect on IPD Operations.

Coples of Mr. Cordiner's letter of April 21, 1961 announcing the establishment of an auditing program directed toward disclosure of possible violations of the ant1-trust laws were distributed.

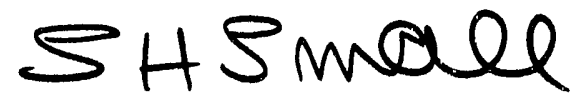




\section{DECLASSFFIID}

HW-69835

\section{REIATIONS PRACTICES}

One PhD was interviewed with no offer extended. Three offers made to ANP Idaho Falls and Cincinnati employees have been accepted. Four requisitions remain open at month end. Four technical graduates transferred into the department from Hanford Laboratories. Two monthly employees transferred from Construction Engineering \& Utilities and one transferred to Contract and Accounting.

A total of $\$ 737.50$ was paid to 18 suggesters. The largest award was $\$ 300$.

Communication activities included publication of nine Management News Bulletins, two Headliners and two priority messages. GE NEWS coverage included 11 items about IPD activities totaling 227 column Inches. Four HAPO-OPGs and three IPD-OPGs were issued in May.

Four IPD employees retired during the month.

There were 85 medical treatment injuries, one disabling injury, one serlous accident and five security violations during the month.

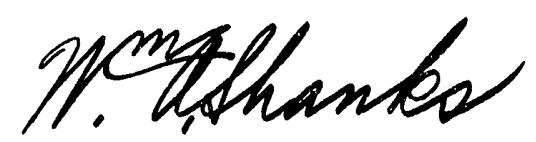

Manager, Relations Practices

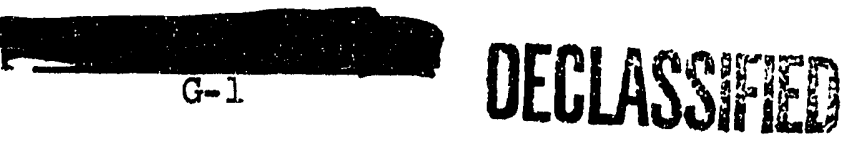




\section{DECLASSIFED}

$-$

HW-69835

SIGNIFICANT REPORIS ISSUID

\begin{tabular}{|c|c|c|c|c|}
\hline Number & Classification & Author & Date & Title \\
\hline $\begin{array}{l}\text { HW-69288 } \\
\text { RD2 }\end{array}$ & Unclassified & GL Swezea & $4-17-61$ & $\begin{array}{l}\text { 109-N Instrumentation } \\
\text { and Control Scope }\end{array}$ \\
\hline BW-69359 & Secret & WL Bunch & $5-15-61$ & $\begin{array}{l}\text { C Reactor Overbore } \\
\text { Study }\end{array}$ \\
\hline EW-69304 & Unclassified & FJ Mollerus, Jr. & $5-31-61$ & $\begin{array}{l}\text { NPR Secondary Coolling } \\
\text { System Response During } \\
\text { Scram }\end{array}$ \\
\hline BW-69466 & Confidential & MC Praser & $5-9-61$ & $\begin{array}{l}\text { Longitudinal Clearance } \\
\text { Between an NPR Process } \\
\text { Tube and 1ts Charge }\end{array}$ \\
\hline BW-69488 & Unclassified & J Muraoks & $5-1-61$ & $\begin{array}{l}\text { Steam-Water Critical } \\
\text { Flow Test Design } \\
\text { Test } 1040\end{array}$ \\
\hline$B W-69620$ & Secret & DI Condotta & $5-16-61$ & $\begin{array}{l}\text { Reactor Design Analy- } \\
\text { s1s Monthly Report - } \\
\text { April, 1961 }\end{array}$ \\
\hline $\begin{array}{l}\text { BW-57043 REVI } \\
\text { ADDI RD }\end{array}$ & Unclassifled & ER Kosmata & $5-5-61$. & $\begin{array}{l}\text { 100-1 Design Bases - } \\
\text { Part I - Addendum I } \\
\text { Phase III OperatIng } \\
\text { CondItIons }\end{array}$ \\
\hline $\begin{array}{l}\text { BW- } 57043 \text { REVI } \\
\text { ADDI RD2 }\end{array}$ & Confidential & HR Kosmata & $5-18-61$ & $\begin{array}{l}\text { 100-N Design Bases - } \\
\text { Part I Addendum I } \\
\text { Phase III Operating } \\
\text { Conditions }\end{array}$ \\
\hline $\mathrm{HW}-69553$ & Unclassiffed & FJ Mollerus, Jr. & $5-31-61$ & $\begin{array}{l}\text { Stabillity Analyses of } \\
\text { the NPR Drmp Condensers }\end{array}$ \\
\hline $\begin{array}{l}\mathrm{HW}-57036 \mathrm{REVI} \\
\mathrm{RD} 3\end{array}$ & Unclassified & GE Wade & $5-5-61$ & $\begin{array}{l}\text { Flssion Product Con- } \\
\text { fInement System }\end{array}$ \\
\hline BN-69562 & Unclassified & WS Seginski & $5-17-61$ & $\begin{array}{l}\text { Compresalon Tests, } \\
\text { NPR Graph1 te Moderator }\end{array}$ \\
\hline None & Unclassified & WJ Love & $5-9-61$ & $\begin{array}{l}\text { IPR Process Tube Strain } \\
\text { Characterlist1cs Dur1ng } \\
\text { Br1ttle Rupture }\end{array}$ \\
\hline BW-66179 ADDI & Confident1al & $\begin{array}{l}\text { WJ Love } \\
\text { D Marinos } \\
\text { JR Spink }\end{array}$ & $5-9-61$ & $\begin{array}{l}\text { NPR Process Tube Rupture } \\
\text { Stack Lift Test Report - } \\
\text { SUPP } 1\end{array}$ \\
\hline
\end{tabular}




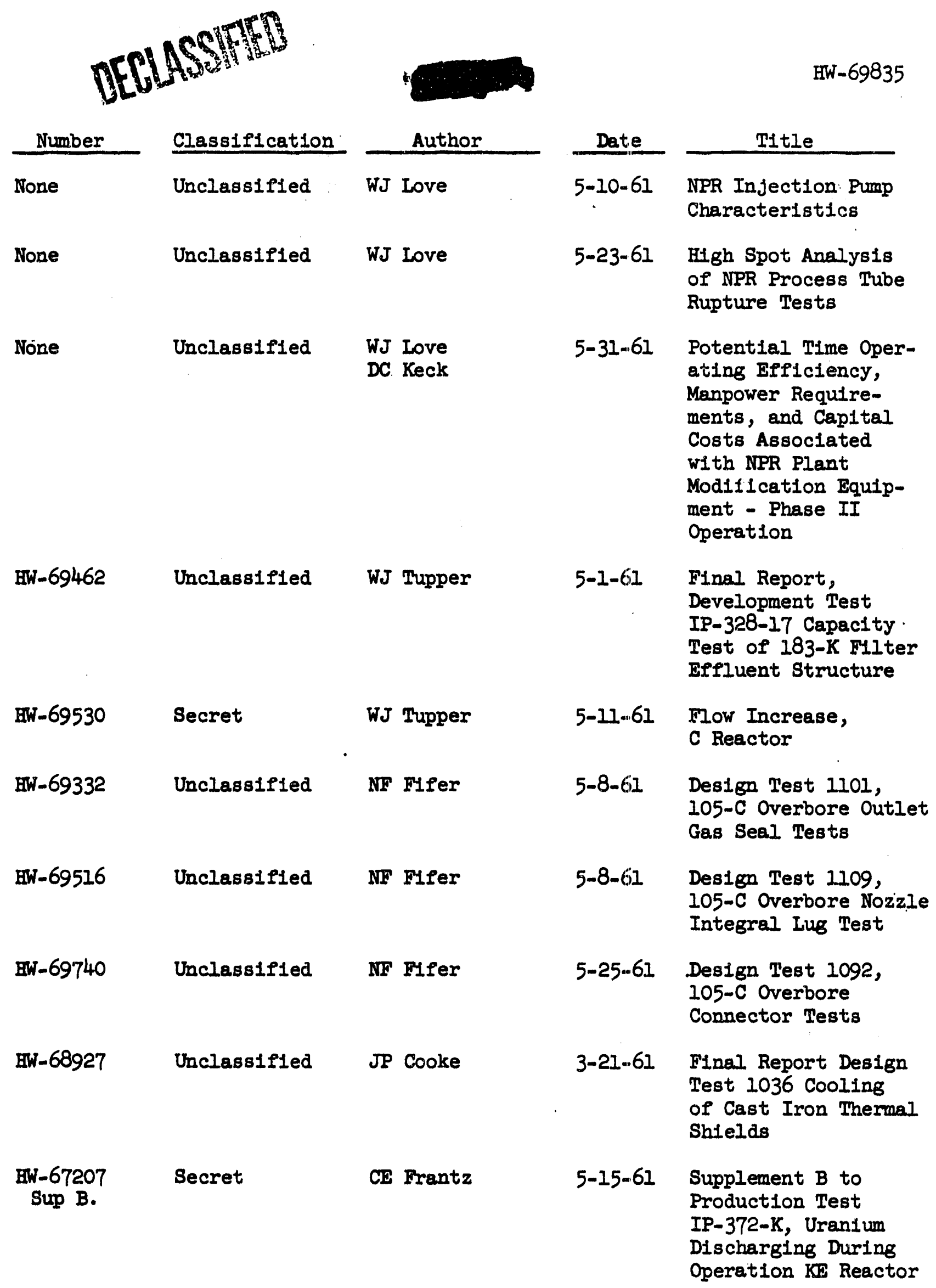


HW-69835

\begin{tabular}{|c|c|c|c|c|}
\hline Number & Class1fication & Author & Date & Title: \\
\hline HW- 69432 & Unclassified & CE Frantz & $5-1-61$ & $\begin{array}{l}\text { Performance Test } \\
\text { Results, Remotely } \\
\text { Operated Tube } \\
\text { Closure Device }\end{array}$ \\
\hline None & Unclassified & KF Eawkins & $5-24-61$ & $\begin{array}{l}\text { On-Reactor Testing } \\
\text { of CGI-824 Components }\end{array}$ \\
\hline None & Unclassified & PB McCarthy & $5-24-61$ & OCD Pressure Data \\
\hline None & $\begin{array}{c}\text { Unclassified } \\
.\end{array}$ & R Sherrard & $5-9-61$ & $\begin{array}{l}\text { Preliminary Spec1- } \\
\text { flcation for H1gh } \\
\text { Speed Scanning } \\
\text { System and Data } \\
\text { Logg1ng for Reactor } \\
\text { Temperature Monftoring }\end{array}$ \\
\hline None & Unclassifled & JD Maguire & $4-26-61$ & $\begin{array}{l}\text { Cross-Threaded Pigtail } \\
\text { Fittings }\end{array}$ \\
\hline None & Unclassifled & JD Maguitre & $4-26-61$ & $\begin{array}{l}\text { Interim Report No. I } \\
\text { B-D-F Rear Header } \\
\text { Adapter Repair Method } \\
\text { Testing }\end{array}$ \\
\hline $\begin{array}{l}\text { HW-68191 } \\
\text { Sup. }\end{array}$ & Unclassifled & RJ Robinson & $5-1-6 i$ & $\begin{array}{l}\text { Des1gn Test } 1051-\text { NPR } \\
\text { Statis Tube Deflection } \\
\text { Supplemental Test Report }\end{array}$ \\
\hline EW-69458 & Unclassifled & WIGB Lander & $5-2-51$ & $\begin{array}{l}\text { Evaluation of Low } \\
\text { Pressure Flow Regulators } \\
\text { for CGI-904 }\end{array}$ \\
\hline HWW-66179 ADDI & Confidential & $\begin{array}{l}\text { WJ Love } \\
\text { D Marinos } \\
\text { JR Spink }\end{array}$ & $5-9-61$ & $\begin{array}{l}\text { NPR Process Tube Rupture-- } \\
\text { Stack Lift Test Report-- } \\
\text { Supplement } I\end{array}$ \\
\hline None & Unclassifled & JD Maguire & $5-11-61$ & $\begin{array}{l}\text { Leak Test - Inconel } \\
\text { P1gta1ls }\end{array}$ \\
\hline None & Unclassified & JD Magulre & $5-16-61$ & $\begin{array}{l}\text { Des1gn Test } 1101 \text { - Outlet } \\
\text { Ges Seal Tests for C- } \\
\text { Overbored Tubes }\end{array}$ \\
\hline HW- 69383 & Secret & RT Jaske & $5-2-61$ & $\begin{array}{l}\text { Flow and Temperature Test } \\
\text { Levels for DDR-131 }\end{array}$ \\
\hline $\begin{array}{l}\text { EW-69590 } \\
\text { PIA }\end{array}$ & Unclassfifled & JC Baudend1stel & $5-15-61$ & $\begin{array}{l}\text { Development Test IP-411-E } \\
\text { Modified Bo1ler Controls } \\
\text { 184-F Building }\end{array}$ \\
\hline
\end{tabular}




\begin{tabular}{l} 
Number \\
\hline HW-69724 \\
HW-69652 \\
Name \\
JE St1ce \\
GT Haugland
\end{tabular}

AD Dunning CE Bonham

WM Barty

IG Henke

CL Goss

WJ Mundt

GI Wade
Classification

Unclassifled

Unclassteled
WD Richmond

Author
WD RIchmond

CR Barker
Date

$5-25-61$

Ifght Water Injection into PRTR Primary Coolant System

$5-18-61$
Interim Report on Rear Van Stone Flange Formation

TRIPS

Firm \& Location
Baldwin-Lima-Hamilton
Eddystone, Pennsylvania

Pratt Whitney and Company 5-17-61 Hartford, Connecticut

Yuba Consolidated Industries

Benecla, California

Ladish Company

Cudahy, Wisconsin

Computer Users' Symposium Ut1ca, New York

Av1en, Inc., Woodside, Long Island, New York

Burns and Roe, Inc. Hempstead, New York

Amerlcan Nuclear Soc1ety 4-21-61 Conference

New York, N. Y.

Whitlock Manufacturing

Company

Hartford, Connecticut

Henry Pratt Co. ChIcago, Illinols

\section{Date \\ $5 / 2-4 / 61$}

$5-23-61$

$5-22-61$

$5 / 4-5 / 61$

$5-6-61$

$5 / 8-12 / 61$
$4-24-61$

$4-25-61$ Purpose
To revlew progress of fabrication of thermo- shield

To review progress on front and rear nozzle fabrication.

To revlew progress on primary shield. crate fabrication.

To discuss Atwood \& Morrill valve forgings.

Attend symposium.

Review flow monitor package.

To review scope.

Conference concerning start-up problems associated with the Yankee reactor.

Discuss problems assoclated with rupture monttor heat exchangers.

Discuss scheduling problems with the confinement system butterfly valves. 
Name

Jis Nesb1tt

QA Newe11

WJ Dow1 a

MH Schack

ER Rudock

MA Bchack

cA Munro

RR Henderson BC Wood
Firm \& Iocation

PEL Frgineers

Compton, California

Smith Dynamics, Harvey Aluminum Co. and Tools, Inc.

Ios Angeles, Califorala Rucker Company

Qakland, California

Weshington, D. C.

ASISE

Hydraulics Conference

Montreal, Caneda

Whitlock Mfg. Ca. Hartford, Conn.

GR RIch

Boston, Mass.

Norfin, Inc.

Seattle, Wash.

Iinde Alr Reduction Co. San Francisco, Cal.

Stryco Manufacturing Co. San Francisco, Cal.

GE-APED - Vallecitos \&

San Jose, Cal.
Date

$5 / 4-5 / 61$

$5 / 15-16 / 61$

Discuss design and fabrication problems on horizontal rod equipment.

$5-17-61$

$5 / 13-21 / 61$

Assist in presentation of testimony on NPR before the JCAE.

5-8-61

5/10-14/61 Witness final assembly. of heat exchangers for CGI839.

$5-10-61$

Discuss Hanford Export Water System Design Nodiflcations

5/15-16/61 To discuss Contract DDR-129 for a new tri-bore machine.

$5 / 10-13 / 61$

To revlew the operation of hellum recovery equipment at NASA, Moffet Fleld. To dscuss equipment for welding instrument sensing IInes for NPR.

To discuss recent activity in the fleld of reactor and reactor component decontamination.

\section{IIG Bawletns}

Raybestos-Manhattan, Inc. 5/19-24/61 Dow Corning Corp. U.S. Stoneware Co. Union Carbide Plastics Co. U.S. Rubber Company Detroit, Michigan Design Engineering Show \& ABMIE Conference-Detro1t, Mich.
To discuss tube end closure seal problems in relation to OCD. 
Name

HA Kramer

AW Hervin

IIL Btheridge

FJ Mollerus

JM Fox, Jr.

DS Iew18

NiN Mattu

JE Hanson

EJ Nesselson

DE Curt1ss

RW Benoliel

WA Bura?

FIrm \& Location
Ioth Pacific Northwest
Industrial Conference
WSU, Pullman, Wash.

Edwards Bquipment Co. Yakima, Wash.

Weshington State UnIV. Pullman, Wash.

Pratt \& Whitney

Hartford, Conn.

Burns \& Roe

New York City

Duquense IIght Co. Pittsburg, Penn.

Byron-Jackson Co. Ios Angeles, Calif.

Byron-Jackson Co. Ios Angeles, Calif.

Purdue Untversity Lafayette, Ind.

Bridgeport Brass Co. RIverside, Calif.

Harvey Aluminum Co. Torrance, Cal1f.

National Reactor Test

Station

Idaho Fells, Idaho

Cleveland, Oh1o

Cleveland Flectric

IIluminating Co.

Cleveland, Ohfo
Date

Purpose

$5 / 25-26 / 61$

To obtain information on river developments related to BAPO interests.

5-19-61 To 1nspect and w1tness test of straddle tratler.

5-13-61 Perform functions as secretary and judge AIFE 9th District Student Paper contest.

5-18-61 Discuss NPR metallurgy.

5-19-61 Discuss NPR metallurgy.

$5 / 23-24 / 61$

Attended a meeting of the American Standard Association

$5 / 3-5 / 61$

Witness disassembly and re-assembly of canned rotox pumps for use in 1706-KKR.

4/27-5/5/61. Observe assembly and disassembly of KGR primary pumps.

4/29-5/7/61 Attend Industrial Water \& Wastes Conf.

$5 / 1-9 / 61$ Discuss orders for NPR fuel jackets.

"

"

$5-3-61$

Discussion of test irradiation request for NPR graphite

$5 / 5-14 / 61$

Attend Jolnt CongressAIChE and Chemical Institute of Canada

Discuss pressure power plant design. 


\begin{tabular}{|c|c|c|c|}
\hline \multirow[t]{2}{*}{ Name } & Firm \& Locat1on & Date & Purpose \\
\hline & $\begin{array}{l}\text { Atomic Power Development } \\
\text { Assoclates, Ind. }\end{array}$ & & $\begin{array}{l}\text { Observe Fermi Reactor } \\
\text { design. }\end{array}$ \\
\hline \multirow[t]{2}{*}{ SS Jones } & Montreal, Canada & $5 / 6-11 / 61$ & $\begin{array}{l}\text { Attend National } \\
\text { Hydraulic Conference- } \\
\text { Amerlcan Soclety of } \\
\text { Mechanlcal Englneers }\end{array}$ \\
\hline & $\begin{array}{l}\text { Dresden Power Station } \\
\text { Morr1s, Illinols }\end{array}$ & & $\begin{array}{l}\text { Inspect site and } \\
\text { review safety features. }\end{array}$ \\
\hline WR Conley & $\begin{array}{l}\text { Burns and Roe } \\
\text { New York, N.Y. }\end{array}$ & $5 / 6-12 / 61$ & Discuss ITPR design. \\
\hline \multirow[t]{2}{*}{ TW Evans } & $\begin{array}{l}\text { General Atomics } \\
\text { San Diego, Calif. }\end{array}$ & $5 / 8-13 / 61$ & $\begin{array}{l}\text { Attend ABC Corrosion } \\
\text { Symposium. }\end{array}$ \\
\hline & $\begin{array}{l}\text { Atomics International } \\
\text { Los Angeles, Calif. }\end{array}$ & & $\begin{array}{l}\text { Discuss fuel element } \\
\text { and metallurgy problems } \\
\text { and programs. }\end{array}$ \\
\hline RE Trumble. & $\begin{array}{l}\text { Bonneville Power Admin. } \\
\text { Portland, Ore. }\end{array}$ & $5 / 11-12 / 61$ & $\begin{array}{l}\text { Consult on NPR power } \\
\text { distribution. }\end{array}$ \\
\hline \multirow[t]{2}{*}{ JS Stoakes } & San Jose, Cal1f. & $5 / 21-23 / 61$ & $\begin{array}{l}\text { Attend GE Western } \\
\text { Technical Bducation } \\
\text { Conference. }\end{array}$ \\
\hline & \multicolumn{2}{|c|}{ VISITORS } & \\
\hline F Steinbrucker & $\begin{array}{l}\text { Burns and Roe, Inc. } \\
\text { Hempstead, New York }\end{array}$ & $5 / 2-5 / 61$ & $\begin{array}{l}\text { Discuss electrical } \\
\text { clrcults. }\end{array}$ \\
\hline T Russell & $\begin{array}{l}\text { Burns and Roe, Inc. } \\
\text { Hempstead, New York }\end{array}$ & $5 / 16-19 / 61$ & $\begin{array}{l}\text { Discuss piping } \\
\text { insultation. }\end{array}$ \\
\hline R Shanks & $\begin{array}{l}\text { Automation Products } \\
\text { Spokane, Washington }\end{array}$ & $5-17-61$ & $\begin{array}{l}\text { Showed a fllm on } \\
\text { flareless flttings. }\end{array}$ \\
\hline $\begin{array}{l}\text { HWr Dav1d } \\
\text { JK Loeser } \\
\text { CH Barnard } \\
\text { PB SnIth }\end{array}$ & $\begin{array}{l}\text { Bailey Meter Company } \\
\text { Cleveland, Ohlo } \\
\text { Balley Meter Company } \\
\text { Seattle, Washington. }\end{array}$ & $5 / 24-26 / 61$ & $\begin{array}{l}\text { Bxchange Information } \\
\text { on the } 109-N \text { Instru- } \\
\text { mentation and control } \\
\text { system. }\end{array}$ \\
\hline GL Locke & $\begin{array}{l}\text { Private Consultant } \\
\text { Joseph, Oregon }\end{array}$ & $5 / 11-25 / 61$ & $\begin{array}{l}\text { Discuss work on } \\
\text { evaluation of flow from } \\
\text { large pipe ruptures. }\end{array}$ \\
\hline & & & \\
\hline
\end{tabular}


Name

WA Spraker

JM Herman

I Correll

WW Barton

WB P1tman

IG Burns

EIS Francis

N Sarchtn

RT Dearborn

CA Maudry H GIIbert

AJ Lolacono

Prof. R. F. Larson

EF Potter

Ix Ioop
Firm \& Location

Battelle Memorial

Inst1tute

Washlngton, D.C.

Allied Pacific Manu-

facturing Company

Compton, California

Whitlock Company

Hartford, Connecticut

AMF Atomics Corporation Greenwich, Connecticut

Chandler Brans

Hartford, Connecticut

Chandler Evans

Seattle, Washington

Mason and Neilan

Norwood, Massachusetts

Harvey Aluminum Co.

Ios Angeles, California

Burns and Roe, Inc. Hempstead, New York

University of Illinois

Urbana, Illinols

Large Steam Turbine Div. General Blectric Co. Schenectady, New York

Atomic Dnergy Commission 5-3-61 Chlcago, Illinols

$5-9-61$
Date

Purpose

$5-22-61$

Discuss heat transfer and fluld dynamic data applicable to production reactors.

5-25-6I Review recent technology concerned with bolling heat transfer and two-phase fluid flow studies.

Discuss fabrication requirements of the process tube assembly thimble.

$5-15-61$

Discuss rupture monltor heat exchangers P.0. KE-8196.

5/11-12/61 Discuss Irradiated metal handling.

5-16-61 Revlew status and degree of acceptability for report on inlet and diversion valves.

5-25-61 Review status and degree of acceptabllity for report on inlet and diversion valves.

5/17-18/61 D1scussions concerning Zirconium production.

5-24-61 Review design and construction act1vity.

5/3-11/61 Discuss heat transfer research.

$5 / 29$ to month end

Consultation on primary piping problems.

To Inquire into reactor safety aspects of the proposed N Reactor dump system. 
Name

B Gallion

R McGurk

J Barnes

W Christian

V Lawford

$W$ Kamsler

W Gunning

CG Lennox

CJ Hoffmiller

LC Ford

HPP Va1l

Weller Reed

FP Luca

TG Cooper

Wo Helwig
F1rm \& Iocation

Imperial Eastman Corp. Portland, Ore.

Teleflex Corp. Midland, Michigan

Barton Instruments

Monterey Park, Cal.

Epsco-West Anaheim, Cal.
Date

5-4-61

$4-28-61$

$5-3-61$

A.E.C.I.

Chalk River, Canada

General Electric Co. Portland, Ore.

General Electric Co. Portland, Ore.

General Hilectric Co. Seattle, Wash.

Consultant

Ios Angeles

Westinghouse Corp.

Seattle, Wash.

CE Riggs Co. Portland, Ore. Helwig Carbon Products Milwaukee, Wis.

$5-9-61$
Purpose

To discuss tubing fittings

Vendor inspection and testing of Teleflex charge seaters.

To discuss four channel prototype under test in 1713-D Laboratory and to supply data taken on the prototype at the factory.

To Install and test modified high speed scanner amplifters and discuss tentative high speed scanner speciflcations to be used as basis for contract negotiation relative to doing advanced design and costing of full scale high speed scanner system.

5-11-61 To exchange Information on reactor temperature and llow monitorling (high speed scanner) and nuclear instrumentation. (Escorted by WP Foote, HOO-ABC)

5/2-7/6I To inspect steam valves.

5/7-18/61 To inspect turbines and motors.

5/15-23/61 To provide consultation on steam bollers.

5-22-61 To discuss steam turbine operating problems.

5-25-61 To review brush problems in $\mathrm{K}$ Area. 


\section{DECLASSFFED}

Name

S Potter

Welding

Consultant

JR Wolcott

AI Scheideler

FB Hübbard

BA Hendon

GA Moudry

III GIIbert
F1rm \& Iocation.

Turbine Division

General Electric

Schenectady, N. Y.

Atomic Power Equip.

Department

Sen Jose, Calif.

Harvey Aluminum Co. Torrance, Calif.

Harvey Aluminum Co. Torrance, Calif.
Date

$5-31-61$

Welding on NPR Primary Piping.

4/27-28/61 Discuss instrumentation for reactor control.

5/16-18/61 Discuss NPR zirconium process tube procurement.

5/17-19/61 Discuss orders for N Reactor fuel program. 

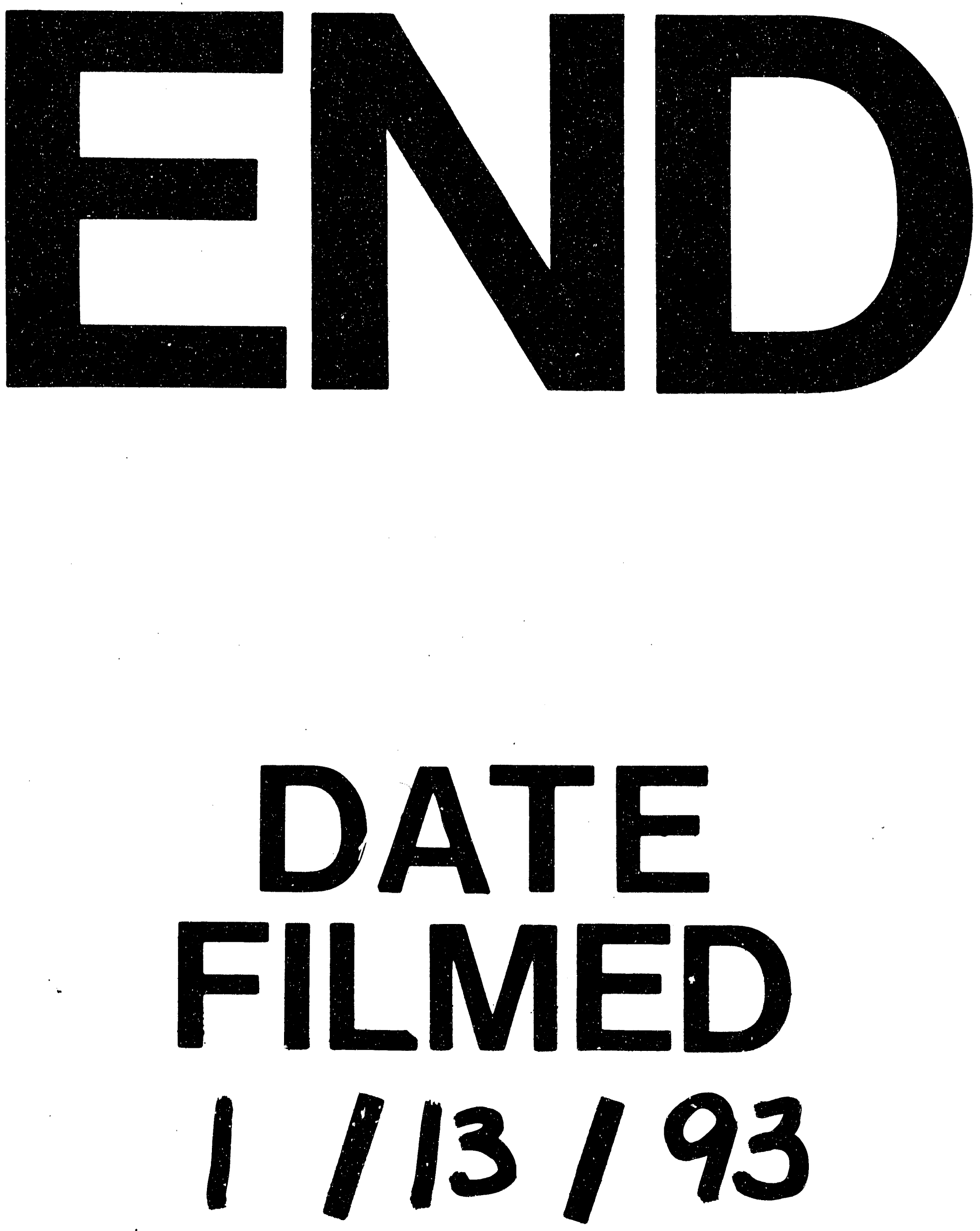
